\title{
A review of the diagnosis and geographical distribution of the recently described flea toad Brachycephalus sulfuratus in relation to B. hermogenesi (Anura: Brachycephalidae)
}

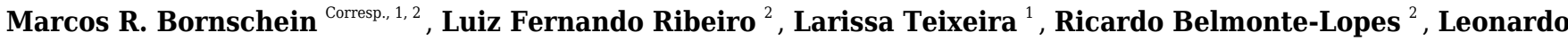 \\ Amaral de Moraes ${ }^{3}$, Leandro Corrêa ${ }^{2}$, Giovanni Nachtigall Maurício ${ }^{3}$, Júnior Nadaline ${ }^{2,4}$, Marcio R Pie ${ }^{2,4}$ \\ 1 Departamento de Ciências Biológicas e Ambientais, Universidade Estadual Paulista, São Vicente, São Paulo, Brazil \\ 2 Mater Natura - Instituto de Estudos Ambientais, Curitiba, Paraná, Brazil \\ 3 Programa de Pós-Graduação em Biologia Animal, Universidade Federal de Pelotas, Pelotas, Rio Grande do Sul, Brazil \\ 4 Departamento de Zoologia, Universidade Federal do Paraná, Curitiba, Paraná, Brazil \\ Corresponding Author: Marcos R. Bornschein \\ Email address: marcos.bornschein@unesp.br
}

Background. The flea toad Brachycephalus sulfuratus was recently described from southeastern and southern Brazil. In its description, the authors overlooked previous records of flea toads that had been identified as "Brachycephalus sp. nov." and $B$. hermogenesi occurring in the same regions, which could suggest the possibility of up to three flea toads coexisting in southern Brazil. In addition, $B$. sulfuratus is characterized by substantial phenotypic variability, to an extent that compromises its current diagnosis with respect to its congener $B$. hermogenesi. Therefore, the current state-of-affairs regarding the geographical distribution of these two species and the identification of previously known populations is hitherto uncertain. Our goals are to reassess previous records of flea toads attributable to $B$. hermogenesi, B. sulfuratus, and "Brachycephalus sp. nov.", considering the description of $B$. sulfuratus, and to review the diagnosis of $B$. sulfuratus. Methods. A critical analysis of the species identity of flea toad specimens attributable to $B$. hermogenesi, $B$. sulfuratus, or to a potentially undescribed species from southeastern and southern Brazil was based either on the analysis of morphology or on their advertisement calls. These analyses include our independent examinations of specimens and, when not possible, examinations of published descriptions. To allow for a consistent comparison of advertisement calls between $B$. hermogenesi and $B$. sulfuratus, we made recordings of both species, including in the type locality of the former. Results. We found that morphological and call characters originally proposed as diagnostic for $B$. sulfuratus in relation to $B$. hermogenesi vary intraspecifically. Live individuals with ventral yellow spots correspond to $B$. sulfuratus; individuals without yellow spots can be either $B$. sulfuratus or $B$. hermogenesi. In preservative, they are indistinguishable. Previous records of Brachycephalus sn nov corresnond to $R$, sulfuratus. We propose that the reduced number 
of notes per call and the presence of only isolated notes in the call of $B$. sulfuratus, as opposed to a high number of notes per call with isolated notes and note groups in the call of $B$. hermogenesi, as the only diagnostic characters between them. Regarding their distributions and based in our assessment, only $B$. sulfuratus occurs in southern Brazil, without any overlap with $B$. hermogenesi. There is a narrow gap between the distributions of these species around the southeast of the city of São Paulo. Our revision also revealed that some records previously attributed to $B$. hermogenesi in Rio de Janeiro and north São Paulo represent a distinct, unidentified flea toad that is not $B$. sulfuratus. Both species occur side by side in Corcovado, São Paulo, a locality from where five paratypes of $B$. hermogenesi were obtained. Biogeographic events that might have led to vicariance between $B$. hermogenesi and $B$. sulfuratus are discussed. 


\section{A review of the diagnosis and geographical}

\section{2 distribution of the recently described flea toad}

\section{Brachycephalus sulfuratus in relation to $B$.}

\section{4 hermogenesi (Anura: Brachycephalidae)}

5

6 Marcos R. Bornschein ${ }^{1,2}$, Luiz F. Ribeiro ${ }^{2}$, Larissa Teixeira ${ }^{1}$, Ricardo Belmonte-Lopes ${ }^{2}$,

7 Leonardo Amaral de Moraes ${ }^{3}$, Leandro Corrêa ${ }^{2}$, Giovanni Nachtigall Maurício ${ }^{3}$, Júnior

8 Nadaline 2,4 , Marcio R. Pie ${ }^{2,4}$

9

10

${ }^{1}$ Departamento de Ciências Biológicas e Ambientais, Universidade Estadual Paulista, São Vicente, São Paulo, Brazil.

${ }^{2}$ Mater Natura - Instituto de Estudos Ambientais, Curitiba, Paraná, Brazil.

${ }^{3}$ Programa de Pós-Graduação em Biologia Animal, Universidade Federal de Pelotas, Pelotas, Rio Grande do Sul, Brazil

${ }^{4}$ Departamento de Zoologia, Universidade Federal do Paraná, Curitiba, Paraná, Brazil.

Corresponding Author:

Marcos R. Bornschein ${ }^{1}$

${ }^{1}$ Departamento de Ciências Biológicas e Ambientais, Universidade Estadual Paulista, Praça Infante Dom Henrique s/no, São Vicente, São Paulo, CEP 11330-900, Brazil.

Email address: marcos.bornschein@unesp.br 


\section{Abstract}

26 Background. The flea toad Brachycephalus sulfuratus was recently described from southeastern

27 and southern Brazil. In its description, the authors overlooked previous records of flea toads that

28 had been identified as "Brachycephalus sp. nov." and B. hermogenesi occurring in the same

29 regions, which could suggest the possibility of up to three flea toads coexisting in southern

30 Brazil. In addition, $B$. sulfuratus is characterized by substantial phenotypic variability, to an

31 extent that compromises its current diagnosis with respect to its congener $B$. hermogenesi.

32 Therefore, the current state-of-affairs regarding the geographical distribution of these two species

33 and the identification of previously known populations is hitherto uncertain. Our goals are to

34 reassess previous records of flea toads attributable to B. hermogenesi, B. sulfuratus, and

35 "Brachycephalus sp. nov.", considering the description of B. sulfuratus, and to review the

36 diagnosis of $B$. sulfuratus.

37 Methods. A critical analysis of the species identity of flea toad specimens attributable to $B$. hermogenesi, B. sulfuratus, or to a potentially undescribed species from southeastern and southern Brazil was based either on the analysis of morphology or on their advertisement calls. These analyses include our independent examinations of specimens and, when not possible, examinations of published descriptions. To allow for a consistent comparison of advertisement calls between $B$. hermogenesi and $B$. sulfuratus, we made recordings of both species, including in the type locality of the former.

44 Results. We found that morphological and call characters originally proposed as diagnostic for $B$. sulfuratus in relation to $B$. hermogenesi vary intraspecifically. Live individuals with ventral yellow spots correspond to $B$. sulfuratus; individuals without yellow spots can be either $B$. sulfuratus or B. hermogenesi. In preservative, they are indistinguishable. Previous records of Brachycephalus sp. nov. correspond to B. sulfuratus. We propose that the reduced number of notes per call and the presence of only isolated notes in the call of B. sulfuratus, as opposed to a high number of notes per call with isolated notes and note groups in the call of B. hermogenesi, as the only diagnostic characters between them. Regarding their distributions and based in our assessment, only B. sulfuratus occurs in southern Brazil, without any overlap with $B$. hermogenesi. There is a narrow gap between the distributions of these species around the southeast of the city of São Paulo. Our revision also revealed that some records previously attributed to $B$. hermogenesi in Rio de Janeiro and north São Paulo represent a distinct, 
56 57 58 59

60

unidentified flea toad that is not B. sulfuratus. Both species occur side by side in Corcovado, São Paulo, a locality from where five paratypes of $B$. hermogenesi were obtained. Biogeographic events that might have led to vicariance between $B$. hermogenesi and B. sulfuratus are discussed.

\section{Introduction}

The genus Brachycephalus Fitzinger, 1826 includes 36 small diurnal anuran species that live in the leaf litter across the Brazilian Atlantic Rainforest (Bornschein, Pie \& Teixeira 2019a). Most species present small geographic distributions, restricted to one ore few adjacent mountaintops (Pie et al. 2013, Bornschein et al. 2016a, Bornschein, Pie \& Teixeira 2019a). Brachycephalus has been divided in three phenetic groups, based on body shape and presence/absence of dermal co-ossification (Ribeiro et al. 2015), and presence/absence of linea masculina (Pie et al 2018a): the B. ephippium group, with 12 species distributed from Espírito Santo and Minas Gerais south to São Paulo, southeastern Brazil (Bornschein, Pie \& Teixeira 2019a); the B. pernix group, with 19 species distributed in Paraná and Santa Catarina, southern Brazil (Bornschein, Pie \& Teixeira 2019a); and the B. didactylus group, with four species commonly known as flea toads and distributed throughout much the Atlantic Forest of Brazil, from Bahia to Santa Catarina, northeastern, southeastern, and southern Brazil (Bornschein, Pie \& Teixeira 2019a). Members of the B. didactylus species group (sensu Ribeiro et al. 2015; Bornschein, Pie \& Teixeira 2019a) are distinguished by their leptodactyliform body shape and the absence of dermal ossification and absence of linea masculina. The B. ephippium species group includes species with bufoniform body shape, presence of dermal ossification and absence of linea masculina, and, finally, the $B$. pernix species group includes species equally with bufoniform body shape but without dermal ossification and with linea masculina (Ribeiro et al. 2015).

The first described flea toad species was B. didactylus, in 1971 (Izecksohn 1971) as the only member of a new genus, Psyllophryne. The second flea toad species, B. hermogenesi, was described nearly three decades later, in 1998 (Giaretta \& Sawaya 1998), at the time as the second species of the genus Psyllophryne. This genus was then synonymized in favor of Brachycephalus when it was discovered that this genus also had an omosternum, whose presence until then exclusive in Psyllophryne diagnosed that genus in relation to Brachycephalus (Kaplan 2002). 
87 Recently, other two flea toads were described, namely B. pulex (Napoli et al. 2011) and B. 88 sulfuratus (Condez et al. 2016). Only recently have flea toads been recorded in southern Brazil. 89 The first records were of B. hermogenesi to the Reserva Particular do Patrimônio Natural Salto 90 Morato (RPPNSM), municipality of Guaraqueçaba, in the northern coast of Paraná (Pereira et al. 91 2010, Santos-Pereira et al. 2011), and at Colônia Castelhanos, municipality of Guaratuba, in 92 southern Paraná, initially as "Brachycephalus aff. hermogenesi" (Cunha et al. 2010) and later as 93 "B. hermogenesi" (Oliveira et al. 2011). Shortly thereafter, Pie et al. (2013) published 14 94 localities of a flea toad identified as "Brachycephalus sp. nov. 1”, from Paraná and Santa 95 Catarina. These authors also reidentified the record from Colônia Castelhanos as 96 “Brachycephalus sp. nov. 1". Occurrences from RPPNSM of Pereira et al. (2010) and Santos97 Pereira et al. (2011) were overlooked by Pie et al (2013). Later, Bornschein et al. (2016a) 98 compiled 18 localities of a flea toad as Brachycephalus sp. 1., including the 14 localities of Pie et al. (2013) treated as “Brachycephalus sp. nov. 1”. Bornschein et al. (2016a) also reidentified 101 102 103 104 105 106 107 108 previous records of the flea toad of the RPPNSM and Colônia Castelhanos as Brachycephalus sp. 1.

After these discoveries, the flea toad B. sulfuratus was described in 2016 based on a series of 28 specimens distributed from southern São Paulo to northern Santa Catarina (Condez et al. 2016). However. these authors did not take into account the information available in Pie et al. (2013) and Bornschein et al. (2016a). Rather, Condez et al. (2016) only considered the presence of the flea toad B. hermogenesi in Paraná, based on Oliveira et al. (2011). However, the voucher specimen of Oliveira et al. (2011), a single specimen deposited in the Museu de História Natural, Universidade Estadual de Campinas, Campinas (ZUEC 16602), was reidentified by Condez et al. (2016) as B. sulfuratus, whereas the remaining records of $B$. hermogenesi in Paraná, from Pereira et al. (2010) and Santos-Pereira et al. (2011), were not considered by Condez et al. (2016).

The absence of a nomenclatural review of records of flea toads in southern Brazil can be evidenced by the fact that a single location in Santa Catarina, called Castelo dos Bugres, was recorded as harboring specimens identified as "Brachycephalus sp. nov. 1" (Pie et al. 2013), or Brachycephalus sp. 1. (Bornschein et al. 2016a), and B. sulfuratus (Condez et al. (2016). No analysis has been carried out to ensure that the unidentified species represents $B$. sulfuratus, so that the uncertainty in the identification of some important occurrence records seems to indicate 
118 three possible scenarios. First, one could envision that potentially there are three similar species 119 of flea toads in Paraná and Santa Catarina, southern Brazil, namely B. hermogenesi (Pereira et al. 120 2010, Santos-Pereira et al. 2011), Brachycephalus sp. (Pie et al. 2013, Bornschein et al. 20016a), 121 and B. sulfuratus (Condez et al. 2016). Second, records of B. hermogenesi in southern Brazil 122 could be erroneous, given that some of these records (Cunha et al. 2010, Oliveira et al. 2011) 123 were assigned to B. sulfuratus or "Brachycephalus sp. nov." (Pie et al. 2013, Condez et al. 2016), 124 leading to an expectation that two species might occur in these regions (B. sulfuratus and 125 Brachycephalus sp.). Third, if the unidentified species of Pie et al. (2013) and Bornschein et al. 126 (2016a) is conspecific of B. sulfuratus, there could be a single species of flea toad in southern 127 Brazil (B. sulfuratus).

128 Recently, Bornschein, Pie \& Teixeira (2019a) reviewed the available occurrence records 129 of flea toads from southeastern and southern Brazil and reverted most of the records of 130 “Brachycephalus sp. nov. 1" (Pie et al. 2013), "Brachycephalus sp. 1" (Bornschein et al. 2016a), 131 and B. hermogenesi from southern Brazil (Pereira et al. 2010, Santos-Pereira et al. 2011, 2016) in 132 favor of $B$. sulfuratus. Some records that could not be adequately reassessed by Bornschein, Pie 133 \& Teixeira (2019a) were reverted to "Brachycephalus sp. cf. B. sulfuratus", including the 134 records of $B$. hermogenesi from Cunha et al. (2010) and Oliveira et al. (2011). Bornschein, Pie \& 135 Teixeira (2019a) disregarded the possibility of a third unnamed species of flea toad in southern 136 Brazil, but one question remains: the proper identification of B. sulfuratus and B. hermogenesi. 137 In this sense, the identification criteria used by Bornschein, Pie \& Teixeira (2019a) to reevaluate 138 the records of flea toads were not indicated. In addition, there may still be uncertainty in the 139 identification of flea toads by other authors, as records of $B$. hermogenesi in southern Brazil 140 continue to be published (Santos-Pereira et al. 2016, 2018, Leivas et al. 2018). Given this 141 uncertainty, the aim of this study is to reanalyze the diagnostic morphological characters used to 142 distinguish $B$. sulfuratus from $B$. hermogenesi and redefine their geographical distributions and 143 distributional limits.

145 Materials \& Methods

146 The critical analysis of the species identity of specimens attributable to Brachycephalus 147 hermogenesi, B. sulfuratus, and to a potentially undescribed flea toad from southeastern and 148 southern Brazil provided in our study was based either on the analysis of their morphology or on 
149 their advertisement calls. We looked for records in museum specimens, in acoustic collections, 150 and in the literature. The analyzed museum collections include Museu de História Natural Capão 151 da Imbuia (MHNCI), Curitiba, Paraná, Brazil, Coleção Herpetológica do Departamento de 152 Zoologia (DZUP), Universidade Federal do Paraná, Curitiba, Paraná, Brazil, and Museu de 153 História Natural (ZUEC), Universidade Estadual de Campinas, Campinas, São Paulo, Brazil. The sound collection analyzed include MHCNI, Xeno-Canto sound collection (www.xeno-canto.org), and Fonoteca Neotropical Jacques Vielliard (FNJV; https://www2.ib.unicamp.br/fnjv/).

The analyses began by the assessment of the original diagnosis of B. sulfuratus (Condez et al. 2016). We looked for the proposed diagnostic characters in museum specimens, calls, sources provided in the literature, and our own photographs of live specimens. Given that this procedure uncovered ambiguity in the proposed diagnostic characters to separate $B$. sulfuratus from $B$. hermogenesi, we sought for new characters that could be useful to distinguish them. New distinctive characters were then erected as diagnostic characters, acting in accordance of the Recommendation 13A of the International Code of Zoological Nomenclature (http://www.iczn.org/).

When comparing the calls between $B$. sulfuratus and B. hermogenesi, we noticed that the calls of $B$. hermogenesi described by Verdade et al. (2008) were from a site $112 \mathrm{~km}$ distant in a straight line from the type locality of this species (Giaretta \& Sawaya 1998). As this distance is considerable in relation to distances between other species of the genus (Pie et al. 2013, Bornschein et al. 2016a), we made additional recordings in the type localities of $B$. hermogenesi (Núcleo Picinguaba and Corcovado; Giaretta \& Sawaya [1998]) and in the locality where Verdade et al. (2008) described the calls of this species (Estação Biológica de Boracéia), as well as in other locations of records of $B$. hermogenesi (e.g., Parque Natural Municipal Nascentes de Paranapiacaba; Verdade, Rodrigues \& Pavan [2009]).

Our recordings, deposited in the MHNCI, were made using analogical (Sony TCM5000EV) and digital (Marantz PMD660, Sony PCM-D50 and PCM-M10, and Tascam DR44WL) devices, with Sennheiser ME 66 and ME 67 microphones. Analogical recordings were digitized at $44.1 \mathrm{kHz}$ and 16 bit using Raven Pro 1.4 (Cornell Lab of Ornithology, Ithaca, New York, USA). Digital recordings were made equally with sampling frequency rate of $44.1 \mathrm{kHz}$ and 16-bit resolution. We analyzed calls under note-centered approach (Köhler et al. 2017), as Bornschein et al. (2018, 2019b) and Pie et al. (2018a). The definition of call used by Condez et 
180 al. (2016) is the one defined by Köhler et al. (2017) as note-centered approach, in which several 181 notes emitted continuously over a period represent the call of the species, in contrast to the call182 centered approach, in which each note represents a call. Remaining call terminology used were 183 those of Bornschein et al. (2018). Spectrograms were produced using Seewave package, version 184 2.1.6 (Suer, Aubin \& Simonis 2008), in R. 4.0.3 (R core team 2018). We made adjustments in 185 contrast and brightness with the intention of lightening the images and best highlighting the

186 187 188 189 pulses. We chose not to noise-filter the spectrograms to avoid eliminating sound characters.

We also included unpublished records in an analysis of $B$. sulfuratus and B. hermogenesi, vouchered with specimens collected and deposited in the MHNCI. Collection permits were issued by ICMBIO (10.500, 22470-2/1911426, and 55918-1). Geographical coordinates are based on the WGS84 datum. Elevations for literature records and author's records were obtained from Google Earth, after plotting the location point (Bornschein et al. 2016a).

Finally, we generated a phylogenetic tree based on a concatenated dataset of all mitochondrial $12 \mathrm{~S}$ and $16 \mathrm{~S}$ mitochondrial loci available on GenBank for specimens of the $B$. didactylus species group (Table S1). Sequences were aligned using MAFFT (Katoh et al. 2002) and analyzed under a single GTRGAMMA model in RAxML 8.2.12 (Stamatakis 2014). Support values were obtained by bootstrapping using the automatic halting option. The final tree was rooted by its midpoint. Whenever possible, the corresponding localities available on their GenBank records were standardized based on the toponyms indicated in Table 1.

\section{Results}

Our list of specimens and calls analyzed of B. sulfuratus and B. hermogenesi, per locality, is provided in Table 1 and Appendix 1.

Diagnosis between Brachycephalus sulfuratus and B. hermogenesi

Condez et al. (2016) indicated three morphological characters to diagnose B. sulfuratus from the very similar $B$. hermogenesi: 1) It "differs from... B. hermogenesi... by having (in life) yellow blotches on the ventral surfaces of the throat, chest, arms, and forearms" (Condez et al. 2016: 43, 50); 2) a more evident "singular inverted v-shaped mark around the cloacal region in ventral view", that is "generally rounded and not ornamented in... B. hermogenesi..." (Condez et al. 2016: 43, 50); and 3) the presence of an "m-shaped mark around the cloacal opening [in 
211 dorsal view], which is... not clearly defined in B. hermogenesi" (Condez et al. 2016: 50).

212 Specimens of B. sulfuratus collected in southern São Paulo, Paraná, and Santa Catarina (Table 1)

213 have revealed that the yellow spots on the ventral surface of this species might still be present, on

214 the throat, chest, arms, and/or forearms, but not necessarily in all of these body parts. In addition,

215 the amount of yellow is highly variable, being virtually absent in some individuals (Fig. 1).

216 Moreover, in three individuals of $B$. sulfuratus collected by us in the state of São Paulo (near the

217 Jurupará dam; Table 1), two do not present yellow spots on the ventral surface (see one of them

218 in Fig. 11), being identified as B. sulfuratus by their advertisement calls (MHNCI 123-5; see

219 below). The inverted v-shaped mark can be absent in individuals of B. sulfuratus (compare Fig.

220 6A of Condez et al. [2016] and Fig. 1a). Additionally, the use of this character is inconsistent as

221 a diagnosis from $B$. hermogenesi on the actual original description: "the ventral inverted v-

222 shaped mark... are shared among the four species [B. sulfuratus, B. hermogenesi, B. didactylus,

223 and B. pulex]" (Condez et al. 2016: 50). Also, while describing the variation on the type series,

224 the authors stated that "some individuals present the inverted v-shaped around the cloacal

225 region" (Condez et al. 2016: 46). Finally, the "m-shaped mark around the cloacal opening" was

226 also mischaracterized as a diagnostic character on the actual original description of the species

227 (Condez et al. 2016: 50): "The m-shaped mark... are shared among the four species $[B$.

228 sulfuratus, B. hermogenesi, B. didactylus, and B. pulex]."

229 Currently, there are no unique morphological character that could differentiate either live

230 or preserved specimens (Fig. 2) for B. sulfuratus from B. hermogenesi. However, for

231 identification purposes, we considered individuals with yellow spots on their ventral side as $B$.

232 sulfuratus, whereas individuals without yellow spots could be either B. sulfuratus or B.

233 hermogenesi. It is important to note that specimens with yellow spots of B. sulfuratus must be

234 observed in life because in the preservative the change in color prevents separate them in relation

235 to specimens of $B$. hermogenesi.

236 In addition to morphological characters, Condez et al. (2016: 43) included in the

237 diagnosis of $B$. sulfuratus the following parameters of the advertisement call: "advertisement call

238 long, composed of a set of 4-7 high-frequency notes $(6.2-7.2 \mathrm{kHz})$ repeated regularly." In the

239 section "Comparisons with other species", Condez et al. (2016: 50) stating that "The

240 advertisement call of B. hermogenesi is the most similar to the new species [B. sulfuratus], being

241 quite similar in frequency (dominant frequency $=6.8 \mathrm{kHz}$ ), which are the highest recorded for

Peer] reviewing PDF | (2020:08:52328:1:1:NEW 5 Jan 2021) 
242 the genus. However, the advertisement call of $B$. hermogenesi can be simple or composed of 2-7 243 shorter notes with 1-3 pulses (Verdade et al. 2008)." In summary, the indicated values overlap 244 with those of $B$. hermogenesi. The advertisement call of $B$. hermogenesi is composed of 1-7 245 notes, whereas that of $B$. sulfuratus is composed of 4-7 notes and the amplitude of the dominant 246 frequency of $B$. hermogenesi $(6.8 \mathrm{kHz})$ is within the range of B. sulfuratus $(6.2-7.2)$.

247 These call descriptions do not allow for a reasonable comparison because they are not 248 necessarily considering the same phenomenon. That is, when it was mentioned that $B$. 249 hermogenesi call can be simple or composed (Verdade et al. 2008), it was being said, according 250 to the note-centered approach (Köhler et al. 2017), that its call can have isolated notes or note 251 groups, but the total number of notes in the entire $B$. hermogenesi call was not mentioned. In

252 253 254 255 256 257 258 259 260 261 262 263 264 265 266 267 268 269

270 271 272 turn, when mentioning that the B. sulfuratus call has $4-7$ notes (Condez et al. 2016), this represents the total number of notes in the call under note-centered approach (sensu Köhler et al. 2017) and that all are isolated notes (see Condez et al. 2016). This is one notorious distinctions between the calls of $B$. sulfuratus and $B$. hermogenesi: the former presents only isolated notes (Fig. 3) and the latter presents isolated notes and note groups (Fig. 4), with note groups having 2-7 notes, according Verdade et al. (2008), or 2-6 notes, according to our samples (Table 2-3). Other particularities of the call of $B$. hermogenesi in relation to the one of B. sulfuratus is the high number of notes per call ( $\geq 24)$ and the presence of "attenuated notes" (Fig. 4F), while in the latter the call has few notes per call $(\leq 8)$ without attenuated notes (Table $2-3$ ). We introduced attenuated notes as a new parameter, provisionally named, to describe weak notes issued before the notes along the calls of $B$. hermogenesi, more strongly perceived in spectrograms than in oscillograms (Fig. 4F). Due to this attenuated condition and difficulty in perceiving these notes, we did not include them as being part of note groups. We detect the presence of one attenuated note emitted before notes from both isolated notes and note groups, all of which from only three calls (MHNCI 167, MHNCI 183, MHNCI 215; Table 2).

Regarding number of pulses per note, B. sulfuratus was described as having 7-11 (Condez et al. 2016), but we found 2-14 (Table 1). Verdade et al. (2008) have not described the number of pulses of notes of $B$. hermogenesi, as stated by Condez et al. (2016:50; "with 1-3 pulses"). However, as we demonstrated, the number of pulses per note for $B$. hermogenesi is indeed 1-3 (Table 2). We noticed that the calls of individuals of two localities previously attributable of $B$. hermogenesi differs from the descriptions above, by having notes with up to 16 
273 pulses and two or rarely three notes in note groups (Fig. 5; Table 1-3). These calls were from

274 Trilha do Corisco, municipality of Paraty, Rio de Janeiro state, and Corcovado, municipality of 275 Ubatuba, São Paulo state (see below; Table 1).

276 We erect as a diagnosis between $B$. sulfuratus and B. hermogenesi the few number of 277 notes per call $(\leq 8)$ with only isolated notes of $B$. sulfuratus, while in B. hermogenesi the 278 advertisement call has a high number of notes $(\geq 24)$ with the presence of isolated notes and note 279 groups (see Table 3). In depth analysis of spectral and temporal parameters of the calls of $B$. 280 hermogenesi will possibly bring other diagnostic parameters, as possibly the note rate, focus of a 281 specific study in the future.

282

283 284 285 286 287 288 289 290 291 292 293 294 295 296 297 298 299 300 301 302 303

Geographical occurrence records of Brachycephalus sulfuratus and B. hermogenesi

Based on our review of the 14 occurrence records of "Brachycephalus sp. nov. 1" from Pie et al. (2013), we conclude that the vouchered records correspond to B. sulfuratus (Table 1). Specimens from Pie et al. (2013) have yellow spots on their ventral side and advertisement calls with few notes and only isolated notes (as above). We treated unvouchered records of Pie et al. (2013) as Brachycephalus sp. (being probably B. sulfuratus; Table 1), with the exception of Castelo dos Bugres, due to the fact that, years later, Condez et al. (2016) collected specimens there, confirming the species' identity as B. sulfuratus. We also determined previously unidentified Brachycephalus records from "Apiaí", "Caratuval", "Corvo", and "Fazenda Thalia" (Firkowski et al. 2016) as B. sulfuratus (Table 1) based on vouchered identification (specimens had yellow spots on their ventral region - see Fig. 1). The records of "Brachycephalus sp. 1" from Bornschein et al. (2016a) correspond to B. sulfuratus (Table 1): all but one of them are the same records as those records presented in Pie et al. (2013) and Firkowski et al. (2016) and were re-identified above. The only exception is the record of "Brachycephalus sp. 1" from RPPNSM, municipality of Guaraqueçaba, Paraná, identified as B. sulfuratus (Table 1) based on their call structure, with few notes and only isolated notes (MHNCI 133; Table 2). On the basis of this record, we reverted in favor of $B$. sulfuratus all other records of B. hermogenesi at RPPNSM (Pereira et al. 2010, Santos-Pereira et al. 2011, 2016, 2018, Leivas et al. 2018; Table 1).

Some previous studies reporting "Brachycephalus hermogenesi" (Giaretta and Sawaya 1998, Dixo and Verdade 2006, Verdade et al. 2008, Condez, Sawaya \& Dixo 2009, Verdade, Rodrigues \& Pavan 2009) from São Paulo do not provide enough morphological evidence or

Peer) reviewing PDF | (2020:08:52328:1:1:NEW 5 Jan 2021) 
304 other details to allow us to reassess their original identification by us (Table 1; Fig. 6). Therefore, 305 we propose that these identifications should be reverted as Brachycephalus sp. (being $B$.

306 hermogenesi or $B$. sulfuratus). One of these records reverted to Brachycephalus sp. involves " $B$.

307 hermogenesi" from the municipality of Piedade, state of São Paulo, of Clemente-Carvalho et al.

308 (2011), whose genetic sequence is deposited in GenBank (HQ435682.1 and HQ435709.1; Table

309 1). The corresponding voucher was obtained by T. H. Condez (pers. comm., 2016) in her study

310 on the same location (Condez, Sawaya \& Dixo 2009). Phylogenetic analyses suggest that it

311 might actually be $B$. sulfuratus, which was placed on the tree together with a specimen from the

312 Municipality of Barra do Turvo, in an early-diverging branch of the B. sulfuratus clade on the

313 tree (Fig. 7).

314 There are some specimens in the original description of B. sulfuratus (Condez et al.

315 2016), from six different localities, cited as " $B$. hermogenesi" in the appendix. It is possible that

316 all of these records were identified based on preserved material, which does not allow for proper

317 identification, as indicated above. Therefore, we also propose that those identifications should be

318 considered as Brachycephalus sp. (being B. hermogenesi or B. sulfuratus; Table 1; see also

319 Bornschein et al. [2016a]).

320 There is a particular specimen, ZUEC 16602 (see introduction), also examined by us,

321 collected in the state of Paraná, that was first identified as "Brachycephalus aff. hermogenesi"

322 (Cunha et al. (2010), later as "B. hermogenesi” (Oliveira et al. (2011), "Brachycephalus sp. nov.

323 1" (Pie et al. 2013), "Brachycephalus sp. 1" (Bornschein et al. 2016a), and, finally as " $B$.

324 sulfuratus" (Condez et al. 2016). There is also the possibility that this specimen may not have

325 been properly analyzed with respect to coloration in life, preventing the precise identification.

326 Therefore, we also propose that this identification should be reverted to Brachycephalus sp.

327 (being probably indeed B. sulfuratus; Table 1).

328 Advertisement calls analyzed of samples from Trilha do Corisco and Corcovado (in

329 part.), two localities previously considered as occurrence of B. hermogenesi (Giaretta and

330 Sawaya 1998, Verdade et al. 2008, Pie et al. 2013, 2018a, Bornschein et al. 2016a, Bornschein,

331 Pie \& Teixeira 2019a; Table 1), have reveal substantial differences to made us to considerer that

332 represents other species, unidentified, but not $B$. sulfuratus (Table 2-3). The call from this third

333 species has two notes forming note groups, exceptionally three, and includes notes with a high

334 number of pulses (up to 16; Table 2-3). Specimens we collected at Corcovado (MHNCI 10823- 
335 5) confirmed that they belong to the B. didactylus species group (sensu Pie et al 2018a). Three

336 adjacent locations based on unvouchered records, Morro Cuscuzeiro. Morro do Corcovado, and

337 municipality of Paraty (Table 1), were referred to as Brachycephalus sp., perhaps

338 Brachycephalus sp. from Trilha do Corisco and Corcovado (Table 1; Fig. 6). This third flea toad

339 Brachycephalus sp. occurs in sympatry with $B$. hermogenesi in Corcovado, as proved by our

340 recordings (B. hermogenesi: MHNCI 165; Brachycehalus sp.: MHNCI 165-205). The

341 phylogenetic analysis revealed that the specimen from Municipality of Paraibuna is indeed $B$.

342 hermogenesi (Table 1), being placed with other specimens of the species collected at the type 343 locality (Fig. 7).

344

\section{Discussion}

Based on our analyses, characters previously used as diagnostic for B. sulfuratus were quite variable and overlapped with those of $B$. hermogenesi. Moreover, the examination of specimens deposited in the collections MHNCI and ZUEC support this claim. Currently, differences in the call structure - number of notes per call and presence/absence of note groups is proposed here as the only available sources of evidence supporting the distinction between $B$. sulfuratus and B. hermogenesi. Even in the field its advertisement calls are very distinct to the human ear and easily distinguishable. The advertisement calls of B. sulfuratus sounds like a “trííííí, trííííí, trííííí, trííííí, trííí'”, whereas the calls of $B$. hermogenesi from it type locality sound like a "tíc, tíc, tíc, tíc-tíc, tíc-tíc-tíc, tíc-tíc-tíc, tíc-tíc-tíc, ...”. These transliterations represent isolated notes or note groups (each note separated by comma and note group by hyphen) with distinct durations (= transliteration size) related to the number of notes in the call. This diagnosis between $B$. sulfuratus and $B$. hermogenesi is only feasible under the note-centered approach. Considering their calls under the call-centered approach, there would be no diagnosis to be proposed between them at this moment, because each note would represent a call (Table 3). To the best of our knowledge, this is the first case in which the diagnosis between species of any Brachycephalus is made solely by characters of their advertisement call.

The first notes emitted from an advertising call by $B$. hermogenesi are usually hardly noticed 363 in the recording and equally difficult to hear in the field. This is the reason why we rarely record the first emissions and many recordings recorded the advertisement call already in progress. 
366

367

368

369

370

371

372

373

374

375

376

377

378

379

380

381

382

383

384

385

386

387

388

389

390

391

392

393

394

395

396

2018; Table 3), assuming that they would reflect the individual's preparation process to the level of excitement required for the issuance of "typical" strongest notes. Like warming notes, attenuated notes could prepare the individual to issue the immediately subsequent notes at a higher level of arousal.

The recognition of the existence of warming notes and attenuated notes, as well as the existence of note groups for understanding the richness of characters in Brachycephalus calls (see also above), consolidate the benefit of the note-centered approach over the call-centered approach in describing calls of species of this genus (Bornschein et al. 2018). The note-centered approach way for description the calls of $B$. hermogenesi also reinforces the hypothesis of complexity increment along note emissions (Bornschein et al. 2018), with the incorporation of note groups during the call emission. These structural particularities would not be perceived under the call-center approach. Under this approach, they would be perceived as a simple intraspecific variation in calls

The advertisement calls of $B$. hermogenesi show the same pattern as species from the $B$. pernix group (Bornschein et al. 2018, 2019b, Pie et al. 2018a, Monteiro et al. 2018a, 2018b), which includes most species of southern Brazil, whereas the call of $B$. sulfuratus resembles the call of $B$. vertebralis (MRB, unpublish data), for example, from the B. ephippium group, which includes most species from the state of São Paulo to the north up to Espírito Santo and Minas Gerais.

We now confirm the absence of occurrence records of $B$. hermogenesi in southern Brazil and the presence of $B$. sulfuratus as far north as the east of São Paulo city, only $25 \mathrm{~km}$ in straight line from the southernmost site of a confirmed record of $B$. hermogenesi (Parque Natural Municipal Nascentes de Paranapiacaba; Fig.6; Table 1). Most unidentified records (Table 1) represent one or the other of these two species. In fact, it is likely that in southern Brazil only the flea toad B. sulfuratus occurs. In this region, our research group has been working with two anuran genera (Brachycephalus and Melanophryniscus) since 2009, focusing on their distribution, ecology and conservation (e.g., Pie et al. 2013, Bornschein et al. 2015, 2016a, Bornschein, Pie \& Teixeira 2019a), and thus are particularly aware of Brachycephalus calls wherever we do field work and yet we never recorded B. hermogenesi calls in southern Brazil.

In addition, we also underscore the absence of records of $B$. sulfuratus in northern Santa Catarina in some well sampled localities. For example, we obtained no records for B. sulfuratus 
397 in Morro Boa Vista $\left(26^{\circ} 30^{\prime} 58^{\prime}\right.$ 'S , 49 $\left.03^{\prime} 14^{\prime \prime} \mathrm{W}\right)$, on the border between the municipalities of

398 Jaraguá do Sul and Massaranduba, where we described B. albolineatus (Bornschein et al.

399 2016b), Morro do Baú (2647'58’'S, 4855'47’W), municipality of Ilhota, and Morro Braço da

400 Onça $\left(26^{\circ} 44^{\prime} 58^{\prime}\right.$ 'S, $\left.48^{\circ} 55^{\prime} 41^{\prime \prime} \mathrm{W}\right)$, municipality of Luiz Alves, where we report B. fuscolineatus

401 (Ribeiro et al. 2015, Bornschein, Teixeira \& Ribeiro 2019c), Morro do Cachorro (2646’42”S, $\left.4024^{\circ} 01^{\prime} 57^{\prime} \mathrm{W}\right)$, on the border between the municipalities of Blumenau, Gaspar, and Luiz Alves, 403 where we described B. boticario (Ribeiro et al. 2015), and Morro Santo Anjo (26³7'41'S, $40448^{\circ} 55^{\prime} 50^{\prime \prime} \mathrm{W}$ ), municipality of Massaranduba, where we described B. mirissimus (Pie et al. 405 2018a). It is possible that the southern limit of the geographical distribution of B. sulfuratus 406 occurs at the Morro do Garrafão (Table 1).

407 Contrary to what is found in southern Brazil, the distribution of flea toads in the states of 408 São Paul and southern Rio de Janeiro are poorly known. Our findings indicate the presence of a 409 third flea toad species at the border between São Paulo and Rio de Janeiro states, at least 410 occurring in Corcovado, São Paulo, and Trilha do Corisco, municipality of Paraty, Rio de 411 Janeiro. Corcovado, however, is one locality of paratypes of B. hermogenesi and Paraty were 412 also cited as a place of occurrence of $B$. hermogenesi in the original description of this species 413 (Giaretta \& Sawaya 1998). The species of the B. didactylus group that occurs closest to Rio de 414 Janeiro/São Paulo border, excluding B. hermogenesi and B. sulfuratus, is B. didactylus, in Vila 415 Dois Rios, Ilha Grande, municipality of Angra dos Reis, Rio de Janeiro (Bornschein, Pie \& 416 Teixeira 2019a). The Trilha do Corisco is distant from Vila Dois Rios $59 \mathrm{~km}$ in a straight line. As we demonstrate in our analyses, there is no confirmed overlap in the distribution of $B$. 418 hermogenesi and B. sulfuratus, and their geographical replacement occurs in southeastern of São 419 Paulo city, without apparent barriers. There are other examples of discontinuity of the 420 geographical distribution between congeneric species throughout the Atlantic Forest from 421 southeastern to southern Brazil in southeastern São Paulo city, as in the montane bird Scytalopus speluncae (taxonomy sensu Maurício et al. [2010]). Maurício (2005) stated that populations of $S$. speluncae from the southeastern of the city of São Paulo to the south of the species distribution represent a distinct species yet to be named, and he treated it as "Southern Scytalopus speluncae" 425 (this scenario of southern population of this bird as a new species was supported by other studies 426 [Bornschein et al. 2007, Mata et al. 2009, Maurício et al. 2014, Pulido-Santacruz et al. 2016]). In 427 the region around the southeastern of São Paulo city, cases of hybridization of subspecies or 
428 lineages have been reported for at least four species of birds (Pinto 1941, Silva and Stotz 1992, 429 Cabanne, Santos \& Miyaki 2007, D’Horta et al. 2011; see also Dantas et al. [2015]). In the state 430 of São Paulo there is another discontinuity which is associated with intraspecific differentiation 431 or even sister species of frogs (Fitzpatrick et al. 2009, Thomé et al. 2010, Amaro et al. 2012) and 432 snakes (Grazziotin et al. 2006).

433 The correspondence between the distribution of the congeneric species in question with 434 the limits of the Serra do Mar is intriguing, given that during the last 20 million years there was 435 no obvious uplift in the region (Gontijo-Pascutti et al. 2012). This time scale is considerably 436 older than the inferred cladogenesis events and therefore geological processes could not have 437 been the primary cause of their divergence, given that Brachycephalus toads and Scytalopus 438 birds of São Paulo, Paraná, and Santa Catarina originated less than 2-5 million years ago (Pie et 439 al. [2018b] and Pulido-Santacruz et al. [2016], respectively). Likewise, recent neotectonic 440 activities (Late Pleistocene-Holocene) are restricted to the faults and stress regimes (Hasui 1990, 441 Saadi, 1993, Riccomini and Assumpção 1999) and, therefore, also could not have generated the 442 diversification pattern of widely distributed terrestrial species. It is important to note that Thomé 443 et al. (2010), studying the toad Rhinella crucifer from the eastern portion of Brazil, associate one

444 445 446

447 448

449

450

451

452

453

454

455

456

457 458 genetic break found in eastern São Paulo to neotectonic barriers, specifically the Cubatão shear zone and the Guapiara lineament. However, these are ancient geotectonic activities, from Proterozoic to Cambrian (with Phanerozoic reactivation) and Mesozoic, respectively (Ferreira et al. 1981, Sadowski 1990, Almeida and Carneiro, 1998; see also Riccomini and Assumpção 1999). In addition, studies have proposed speciation by vicariance caused by relatively recent events, such as river barriers (e.g., Amaral et al. 2013), sea level variation (Grazziotin et al. 2006, Fitzpatrick et al. 2009), and forest refugia (e.g., Fitzpatrick et al. 2009, Thomé et al. 2010, D'Horta et al. 2011, Amaral et al. 2013). The largest river around the disruption of the geographical distribution of B. sulfuratus and B. hermogenesi is the Rio Ribeira do Iguape, which intersects the Serra do Mar between São Paulo and Paraná States by continued erosive retreat (Almeida and Carneiro 1998). Alternatively, the disruption of the Serra do Mar in that region originated from a tectonic depression associated with the asymmetric graben of the Sete Barras or Ribeira de Iguape (Melo et al. 1989, Gontijo-Pascutti et al. 2012). However, the formation of the present configuration of the Serra do Mar did not lead to isolation, given that $B$. sulfuratus occurs on both banks of the Ribeira do Iguape river. It is plausible that the origin of $B$. 
459

460

461

462

463

464

465

466

467

468

469

470

471

472

473

474

475

476

477

478

479

480

481

482

483

484

485

486

487

488

489

sulfuratus and $B$. hermogenesi, as well as the other examples mentioned above, might have resulted from climatic variations that promoted vicariance by forest cover disruption followed by the recovery of forest cover, presumably leading to secondary contact.

The region in the state of São Paulo, around the southeastern São Paulo city, should be further investigated. Records of flea toads in this region could be obtained as background sound in recordings of birds (e.g., recordings deposited in databases such as www.xeno-canto.org and www.wikiaves.com.br; Table 1). Verdade et al. (2008) made a similar suggestion: to search for records of $B$. hermogenesi in the background of recordings of birds from the Estação Biológica de Boracéia, in the case one wants to seek previous records of this flea toad in this highly sampled locality. As examples, calls of B. sulfuratus in Parque Estadual Intervales, municipality of Iporanga, state of São Paulo (Table 1), can be heard in recordings of the birds Merulaxis ater (XC80463 and XC18179) and Eleoscytalopus indigoticus (XC75544; available at www.xenocanto.org), and calls of $B$. hermogenesi in Núcleo Santa Virgínea, Parque Estadual da Serra do Mar, municipality of São Luiz do Paraitinga, São Paulo, can be heard in a recording of $E$. indigoticus (XC253045; Table 1).

We underscore the importance of continuous scrutiny of the distribution and advertisement call analysis of $B$. sulfuratus and $B$. hermogenesi. The advertisement calls of $B$. hermogenesi need to be redescribed (see Pie et al. 2018a:12) and a better understanding of the geographical limits between this species and B. sulfuratus can elucidate distribution patterns and potentially detect cases of sympatry. To date, the occurrence of $B$. hermogenesi and Brachycephalus sp. (other than B. sulfuratus and B. hermogenesi) at Corcovado, São Paulo, is the only confirmed case of sympatry between species of Brachycephalus in the same group. Other cases of sympatry include Brachycephalus from distinct groups (B. pernix and $B$. didactylus groups and B. ephippium and B. didactylus groups; Bornschein et al. [2016a], Bornschein, Pie \& Teixeira [2019a]). Even in sympatry, the differences between the calls of $B$. hermogenesi and Brachycephalus sp. and between B. hermogenesi and B. sulfuratus are substantial and could provide pre-zygotic isolation. Although some species in the B. ephippium group are additively insensitive to the own advertisement call (Goutte et al. 2017), which would suggest loss of active selection pressure and variation maintained by inertia, it must be considered that this scenario may not apply to the other groups (Monteiro et al. 2018a) and, also, that the species may actively perceive call emissions through vibrations in other body receptors. 
490

\section{Conclusions}

492

493

494

495

496

497

498

499

500

501

502

503

504

505

506

507

508

509

510

511

512

513

514

515

516

517

518

519

520

Brachycephalus sulfuratus differs from $B$. hermogenesi only by its advertisement calls; other morphological characters previously suggested to distinguished B. sulfuratus from $B$. hermogenesi are extremely variable and show overlap between these two species. The advertisement calls of these species differ greatly from each other and can be easily recognized by the human ear in the field. Brachycephalus sulfuratus presents few notes per call with only isolated notes and $B$. hermogenesi present high number of notes per call with isolated notes and note groups. The advertisement calls of $B$. sulfuratus resemble those of species of the $B$. ephippium species group, whereas the calls of $B$. hermogenesi resemble those of the $B$. pernix species group. Understanding the evolution of these advertisement calls should require a more in-depth investigation.

All previous records of $B$. hermogenesi from southern Brazil should instead be considered as $B$. sulfuratus, in a possibly cascading error resulting from the inadequate revision of the records prior to the description of $B$. sulfuratus (Condez et al. 2016). A large region in the south of the state of São Paulo needs to be further investigated to confirm the presence of $B$. hermogenesi; the previous records were reverted to Brachycephalus sp. Brachycephalus sulfuratus is distributed much further north than previously thought and it is possible that sympatry with $B$. hermogenesi may occur in the southeast of the city of São Paulo. This region in the southeast of São Paulo is particularly interesting because many species of different taxa have their range limits there. The biogeographic explanation of this pattern seems to be limited to the past distribution of forest patches, which could have been previously isolated and are now distributed continuously, allowing possible secondary contact of species.

The $B$. hermogenesi type series possibly includes a second species of flea toad, not yet identified. This situation involves a locality of a $B$. hermogenesi paratype, and probably not the holotype. Therefore, there is no evidence, at this moment, to suspect the name $B$. hermogenesi as a possible synonym for $B$. didactylus. It is necessary to deepen the field studies to identify the local populations and to clarify the limits of the geographic distribution, as well as to review the identification of museum material, including the type series of $B$. hermogenesi.

Phylogenetic analysis provided evidence that at least $B$. sulfuratus probably includes more than one species under this name, although this species, as presently defined, has a similar 
521 calling pattern in its wide geographical distribution, from southeastern São Paulo to Santa

522 Catarina (Table 1; Fig. 6). In parallel, our B. hermogenesi call analyses provided the first 523 association of a call pattern across the geographic distribution of this species (Table 1; Fig. 6),

524 but this does not mean that only one species is necessarily included under this name, because

525 distinct species of Brachycephalus may have indistinct calls (Pie et al. 2018a.). Combined with 526 the fact that the $B$. didactylus group includes cryptic species, difficult or even impossible to 527 identify in preservative, that occur or can occur locally in sympathy, we recommend a solid and 528 broad review of the taxonomy of the group based on own analyses of large series of specimens 529 and calls.

530

\section{Acknowledgements}

532 Diego Baldo, Stefano Spiteri, and André Confetti provided valuable assistance during field work.

533 Vanessa K. Verdade provided two samples of the advertisement call of Brachycephalus

534 hermogenesi. Milene Fornari provided bibliography for the discussion on biogeography.

535

\section{References}

537 Almeida FFM de \& Carneiro C dal R. 1998. Origem e evolucão da Serra do Mar. Rev Bras Geoc 538

539

540

541

542

543

544

545

546

547

548

549

550

551

$$
\text { 28: } 135-150 \text {. }
$$

Amaral FR do, Patrick KA, Edwards SV \& Miyaki CY. 2013. Multilocus tests of Pleistocene refugia and ancient divergence in a pair of Atlantic Forest antbirds (Myrmeciza). Mol Ecol 22: 3996-4013.

Amaro RC, Rodrigues MT, Yonenaga-Yassuda Y \& Carnaval AC. 2012. Demographic processes in the montane Atlantic rainforest: molecular and cytogenetic evidence from the endemic frog Proceratophrys boiei. Mol Phylogenet Evol 62: 880-888.

Bornschein MR, Firkowski CR, Baldo D, Ribeiro LF, Belmonte-Lopes R, Corrêa L, Morato SAA \& Pie MR. 2015. Three new species of phytotelm-breeding Melanophryniscus from the Atlantic Rainforest of southern Brazil (Anura: Bufonidae). PLoS ONE 10: e0142791.

Bornschein, MR, Firkowski, CR, Belmonte-Lopes, R, Corrêa, L, Ribeiro, LF, Morato, SAA, Antoniazzi-Jr., RL, Reinert, BL, Meyer, ALS, Cini, FA \& Pie, MR. 2016a. Geographic and altitudinal distribution of Brachycephalus Fitzinger (Anura: Brachycephalidae) endemic to the Brazilian Atlantic Rainforest. PeerJ 4: e2490.

Peerj reviewing PDF | (2020:08:52328:1:1:NEW 5 Jan 2021) 
552 Bornschein MR, Ribeiro LF, Blackburn DC, Stanley EL \& PieE MR. 2016b. A new species of

553

554

555

556

557

558

559

560

561

562

563

564

565

566

567

568

569

570

571

572

573

574

575

576

577

578

579

580

581

582

Brachycephalus (Anura: Brachycephalidae) from Santa Catarina, southern Brazil. PeerJ 4: e2629.

Bornschein MR, Maurício GN, Lopes RB, Mata H \& Bonatto SL. 2007. Diamantina Tapaculo, a new Scytalopus endemic to the Chapada Diamantina, northeastern Brazil (Passeriformes: Rhinocryptidae). Rev Bras Ornitol 15: 151-174.

Bornschein MR, Pie MR \& Teixeira L. 2019a. Conservation status of Brachycephalus toadlets (Anura: Brachycephalidae) from the Brazilian Atlantic Rainforest. Diversity 11(150): 1-29.

Bornschein, MR, Rollo Jr., MM, Pie, MR, Confetti, AE \& Ribeiro, LF. 2019b. Redescription of the advertisement call of Brachycephalus tridactylus (Anura: Brachycephalidae). Phyllomedusa 18: 3-12.

Bornschein MR, Teixeira L \& Ribeiro LF. 2019c. New record of Brachycephalus fuscolineatus Pie, Bornschein, Firkowski, Belmonte-Lopes \& Ribeiro, 2015 (Anura: Brachycephalidae) from Santa Catarina state, Brazil. Check List 15: 379-385.

Bornschein MR, Ribeiro LF, Rollo Jr. MM, Confetti AE \& Pie MR. 2018. Advertisement call of Brachycephalus albolineatus (Anura: Brachycephalidae). PeerJ 6: e5273.

Cabanne GS, Santos FR \& Miyaki CY. 2007. Phylogeography of Xiphorhynchus fuscus (Passeriformes, Dendrocolaptidae): vicariance and recent demographic expansion in southern Atlantic forest. Biol J Linn Soc 91: 73-84.

Clemente-Carvalho RBG, Klaczko J, Perez SI, Alves ACR, Haddad CFB \& Reis SF dos. 2011. Molecular phylogenetic relationships and phenotypic diversity in miniaturized toadlets, genus Brachycephalus (Amphibia: Anura: Brachycephalidae). Mol Phylogenet Evol 61: 7989.

Condez TH, Sawaya RJ \& Dixo M. 2009. Herpetofauna dos remanescentes de Mata Atlântica da região de Tapiraí e Piedade, SP, sudeste do Brasil. Biota Neotrop 9: 157-185.

Condez TH, Monteiro JP de C, Comitti EJ, Garcia PC de A, Amaral IB \& Haddad CFB. 2016. A new species of flea-toad (Anura: Brachycephalidae) from southern Atlantic Forest, Brazil. Zootaxa 4083: 40-56.

Cunha AK, Oliveira IS de \& Hartmann MT. 2010. Anurofauna da Colônia Castelhanos, na Área de Proteção Ambiental de Guaratuba, Serra do Mar paranaense, Brasil. Biotemas 23: 123134.

Peerj reviewing PDF | (2020:08:52328:1:1:NEW 5 Jan 2021) 
583 Dantas GPM, Sari EHR, Cabanne GS, Pessoa RO, Marini MA, Miyaki CY \& Santos FR. 2015.

$584 \quad$ Population genetic structure of the Atlantic Forest endemic Conopophaga lineata

585 (Passeriformes: Conopophagidae) reveals a contact zone in the Atlantic Forest. J Ornithol $586 \quad 156: 85-99$.

587 D'horta FM, Cabanne GS, Meyer D \& Miyaki CY. 2011. The genetic effects of Late quaternary 588 climatic changes over a tropical latitudinal gradient: diversification of an Atlantic forest 589 passerine. Mol Ecol 20: 1923-1935.

590 Dixo M \& Verdade VK. 2006. Herpetofauna de serrapilheira da Reserva Florestal de Morro 591 Grande, Cotia (SP). Biota Neotrop 6: 1-20.

592 Ferreira FJF, Moraes RAV, Ferrari MP \& Vianna RB. 1981. Contribuição ao estudo do

593

594

595

596

597

598

599

600

601

602

603

604

605

606

607

608

609

610

611

Alinhamento Estrutural de Guapiara. In: $3^{\circ}$ Simpósio Regional De Geologia, Curitiba:

Sociedade Brasileira de Geologia Núcleo de São Paulo, p. 226-240.

Firkowski CR, Bornschein MR, Ribeiro LF \& Pie MR. 2016. Species delimitation, phylogeny and evolutionary demography of co-distributed, montane frogs in the southern Brazilian Atlantic Forest. Mol Phylogenet Evol 100: 345-360.

Fitzpatrick SW, Brasileiro CA, Haddad CFB \& Zamudio KR. 2009. Geographical variation in genetic structure of an Atlantic Coastal Forest frog reveals regional differences in habitat stability. Mol Ecol 18: 2877-2896.

Giaretta AA \& Sawaya RJ. 1998. Second species of Psyllophryne (Anura: Brachycephalidae). Copeia 1998: 985-987.

Gontijo-Pascutti AHF, Hasui Y, Santos M dos, Soares Jr. AV \& Souza IA de. 2012. As Serras do Mar e da Mantiqueira. In: Hasui Y, Carneiro C dal Ré, Almeida FFM de \& Bartorelli A. (Eds), Geologia do Brasil, Beca, São Paulo, p. 549-571.

Goutte, S, Mason, MJ, Christensen-Dalsgaard, J, Montealegre-Z, F, Chivers, BD, Sarria-S, FA, Antoniazzi, MM, Jared, C, Sato, LA \& Toledo, LF. 2017. Evidence of auditory insensitivity to vocalization frequencies in two frogs. Scientific Reports 7: 12121.

Grazziotin FG, Monzel M, Echeverrigaray S \& Bonatto SL. 2006. Phylogeography of the Botrops jararaca complex (Serpentes: Viperidae): past fragmentation and island colonization in the Brazilian Atlantic Forest. Mol Ecol 15: 3969-3982. 
612 Hasui Y. 1990. Neotectônica e aspectos fundamentais da tectônica ressurgente no Brasil. In: $1^{\circ}$

613 Workshop sobre Neo-Tectônica e Sedimentação Cenozóica Continental no Sudeste

614 Brasileiro, Belo Horizonte, Sociedade Brasileira de Geologia, Boletim 11: 1-31.

615 Izecksohn E. 1971. Novo gênero e nova espécie de Brachycephalidae do Estado do Rio de

616 Janeiro, Brasil. Boletim do Museu Nacional, Zoologia 280: 1-12.

617 Kaplan M. 2002. Histology of the anteroventral part of the breast-shoulder apparatus of

618 Brachycephalus ephippium (Brachycephalidae) with comments on the validity of the genus

619 Psyllophryne (Brachycephalidae). Amphibia-Reptilia 23: 225-227.

620 Katoh K, Misawa K, Kuma K \& Miyata T. 2002. MAFFT: a novel method for rapid multiple

621 sequence alignment based on fast fourier transform. Nucleic Acids Res. 30: 3059-3066.

622 Köhler J, Jansen M, Rodriguez A, Kok PJR, Toledo LF, Emmrich M, Glaw F, Haddad CFB,

623 Rödel M-O \& Vences M. 2017. The use of bioacoustics in anuran taxonomy: theory,

624 terminology, methods and recommendations for best practice. Zootaxa 4251: 1-124.

625 Leivas PT, Calixto, P de O, Crivellari, LB, Struett, MM \& Moura, MO. 2018 Amphibians of the 626 northern coast of the state of Paraná, Brazil. Herpetology Notes 11: 1029-1045

627 Mariotto LR. 2014. Anfíbios de um gradiente altitudinal em mata atlântica. Masters dissertation.

628 Curitiba: Universidade Federal do Paraná.

629 Mata H, Fontana CS, Mauricio GN, Bornschein MR, Vasconcelos MF de \& Bonatto SL. 2009.

630 Molecular phylogeny and biogeography of the eastern Tapaculos (Aves: Rhinocryptidae:

631 Scytalopus, Eleoscytalopus): cryptic diversification in Brazilian Atlantic Forest. Mol

632 Phylogenet Evol 53: 450-462.

633 Maurício G. 2005. Taxonomy of southern populations in the Scytalopus speluncae group, with

634 description of a new species and remarks on the systematics and biogeography of the

635 complex (Passeriformes: Rhinocryptidae). Ararajuba 13: 7-28.

636 Maurício GN, Belmonte-Lopes R, Pacheco JF, Silveira LF, Whitney BM \& bornschein MR.

637 2014. Taxonomy of "Mouse-colored Tapaculos" (II): an endangered new species from the

638 montane Atlantic Forest of southern Bahia, Brazil (Passeriformes: Rhinocryptidae:

639 Scytalopus). The Auk 131: 643-659.

640 Maurício GN, Bornschein MR, Vasconcelos MF de, Whitney BM, Pacheco JF \& Silveira LF.

641 2010. Taxonomy of "Mouse-colored Tapaculos". I. On the application of the name 
642

643

644

645

646

647

648

649

650

651

652

653

654

655

656

657

658

659

660

661

662

663

664

665

666

667

668

669

670

671

672

Malacorhynchus speluncae Ménétriés, 1835 (Aves: Passeriformes: Rhinocryptidae). Zootaxa 2518: 32-48.

Melo MS, Fernandes LA, Coimbra AM \& Ramos RGN. 1989. O gráben (Terciário?) de Sete Barras, vale do Ribeira do Iguape, SP. Rev Bras Geoc 2: 260-262.

Monteiro JPC, Condez TH, Garcia PCA, Comitti EJ, Amaral IB \& Haddad CFB. 2018a. A new species of Brachycephalus (Anura, Brachycephalidae) from the coast of Santa Catarina State, southern Atlantic Forest, Brazil. Zootaxa 4407: 483-505.

Monteiro JPC, Condez TH, Garcia PC. de A \& Haddad CFB. 2018b. The advertisement calls of two species of Brachycephalus (Anura: Brachycephalidae) from southern Atlantic Forest, Brazil. Zootaxa 4415: 183-188.

Napoli MF, Caramaschi U, Cruz CAG \& Dias IR. 2011. A new species of flea-toad, genus Brachycephalus Fitzinger (Amphibia: Anura: Brachycephalidae), from the Atlantic rainforest of southern Bahia, Brazil. Zootaxa 2739: 33-40.

Oliveira AKC de, Oliveira IS de, Hartmann MT, Silva NR da \& Toledo LF. 2011. Amphibia, Anura, Brachycephalidae, Brachycephalus hermogenesi (Giaretta and Sawaya, 1998): new species record in the state of Paraná, southern Brazil and geographic distribution map. Check List 7: 17-18.

Pereira M dos S, Candaten A, Milani D, Oliveira FB de, Gardelin J, Rocha CFD \& Vrcibradic D. 2010. Brachycephalus hermogenesi. Herpetol Review 41: 506.

Pie MR, Meyer ALS, Firkowski CR, Ribeiro LF \& Bornschein MR. 2013. Understanding the mechanisms underlying the distribution of microendemic montane frogs (Brachycephalus spp., Terrarana: Brachycephalidae) in the Brazilian Atlantic Rainforest. Ecol Model 250: 165-176.

Pie MR, Ribeiro LF, Confetti AE, Nadaline MJ \& Bornschein MR. 2018a. A new species of Brachycephalus (Anura: Brachycephalidae) from southern Brazil. PeerJ 6: e5683.

Pie MR, Faircloth BC, Ribeiro LF, Bornschein MR \& Mccormack JE. 2018b. Phylogenomics of montane frogs of the Brazilian Atlantic Forest is consistent with isolation in sky islands followed by climatic stability. Biol J Linn Soc 125: 72-82.

Pimenta BVS, Bérnils RS \& Pombal Jr. JP. 2007. Amphibia, Anura, Brachycephalidae, Brachycephalus hermogenesi: filling gap and geographic distribution map. Check List 3: 277-279. 
673 Pinto OM de O. 1941. Sobre a variação geográfica das populações de Cichlocolaptes leucophrus 674 (Jardine and Selby) com a descrição de uma raça nova. Rev Argent Zoog 1: 165-171. 675 Pulido-Santacruz P, Bornschein MR, Belmonte-Lopes R \& Bonatto SL. 2016. Multiple 676 evolutionary units and demographic stability during the last glacial maximum in the 677 Scytalopus speluncae complex (Aves: Rhinocryptidae). Mol Phylogenet Evol 102: 86-96. 678 R Core Team. 2018. R: A language and environment for statistical computing. Version 4.0.3. 679 Vienna: R Foundation for Statistical Computing. Available at https://www.r-project.org. 680 Ribeiro LF, Bornschein MR, Belmonte-Lopes R, Firkowski CR, Morato SAA \& Pie, MR 2015. 681 Seven new microendemic species of Brachycephalus (Anura: Brachycephalidae) from $682 \quad$ southern Brazil. PeerJ 3: e1011.

683 Ricommini C \& Assumpção M. 1999. Quaternary tectonics in Brazil. Episodes 22: 221-225. 684 Saadi A. 1993. Neotectônica da plataforma brasileira: esboço e interpretações preliminares. 685 Geonomos 1: 1-15.

686 Sadowski GR. 1991. Megafalha de Cubatão no sudeste brasileiro. Boletim IG-USP, Sér Cient, $687 \quad 22: 15-28$.

688 Santos-Pereira M, Candaten A, Milani D, Oliveira FB, Gardelin J \& Rocha CFD da. 2011. 689 Seasonal variation in the leaf-litter frog community (Amphibia: Anura) from an Atlantic 690 Forest area in the Salto Morato Natural Reserve, southern Brazil. Zoologia 28: 755-761. 691 Santos-Pereira M, Milani D, Barata-Bittencourt LF, Iapp TM \& Rocha CFD. 2016. Anuran 692 species of the Salto Morato Nature Reserve in Paraná, southern Brazil: review of the species $693 \quad$ list. Check List 12: 1907.

694 Santos-Pereira M, Pombal Jr. JP \& Rocha CFD. 2018. Anuran amphibians in state of Paraná, 695 southern Brazil. Biota Neotrop 18: e20170322.

696 Silva JMC \& Stotz DF. 1992. Geographic variation in the Sharp-billed Treehunter Heliobletus 697 contaminatus. Bull BOC 112: 98-101.

698 Stamatakis A. 2014. RAxML version 8: a tool for phylogenetic analysis and post-analysis of 699 large phylogenies. Bioinformatics 30(9): 1312-1313.

700 Sueur J, Aubin T \& Simonis C. 2008. Seewave: a free modular tool for sound analysis and $701 \quad$ synthesis. Bioacoustics 18(2): 213-226. 
702 Teixeira L, Ribeiro LF, Corrêa L, Confetti AE, Pie MR \& Bornschein MR. 2018. A second 703 record of the recently described Brachycephalus albolineatus Bornschein, Ribeiro, 704 Blackburn, Stanley and Pie, 2016 (Anura: Brachycephalidae). Check List 14: 1013-1016. 705 Thomé MTC, Zamudio KR, Giovanelli JGR, Haddad CFB, Baldissera Jr. FA \& Alexandrino J. 706 2010. Phylogeography of endemic toads and post-Pliocene persistence of the Brazilian 707 Atlantic Forest. Mol Phylogenet Evol 55: 1018-1031.

708 Verdade VK, Rodrigues MT, Cassimiro J, Pavan D, Liou N \& Lange M. 2008. Advertisement 709 call, vocal activity, and geographic distribution of Brachycephalus hermogenesi (Giaretta 710 and Sawaya, 1998) (Anura, Brachycephalidae). J Herpetol 42: 542-549.

711 Verdade VK, Rodrigues MT \& Pavan D. 2009. Anfíbios anuros da região da Estação Biológica 712 do Alto da Serra de Paranapiacaba. In: Lopes MIMS, Kirizawa M \& Melo MM da RF de 713 (Eds), Patrimônio da Reserva Biológica do Alto da Serra de Paranapiacaba: a antiga Estação 714 Biológica do Alto da Serra, São Paulo: Instituto de Botânica, p. 579-603.

715

716 


\section{FIGURE CAPTIONS}

718

719 Figure 1. Ventral view of life specimens of Brachycephalus sulfuratus initially deposited in 720 DZUP) and transferred to MHNCI. a) MHNCI 11575 (ex-DZUP 153) (Corvo, Paraná); b)

721 MHNCI 11571 (ex-DZUP 139)(Caratuval, near the Parque Estadual das Lauráceas, Paraná); c)

722 MHNCI 11582 (ex-DZUP 224) (Fazenda Thalia, Paraná); d) MHNCI 11579 (ex-DZUP 221)

723 (Fazenda Thalia); e) MHNCI 11573 (ex-DZUP 151) (Corvo); f) MHNCI 11583 (ex-DZUP 362)

724 (base of the Serra Água Limpa, São Paulo); g) MHNCI 11580 (ex-DZUP 222) (Fazenda Thalia);

725 h) MHNCI 11581 (ex-DZUP 223) (Fazenda Thalia); i) MHNCI 10788 (ex-DZUP 154) (Corvo);

726 j) MHNCI 10790 (near the Jurupará dam, São Paulo); k) MHNCI 10826 (Morro do Garrafão,

727 Santa Catarina); 1) MHNCI 10792 (near the Jurupará dam). Notice the variable of yellow spots,

728 absent in specimen "l", as well as the absence of the dark-brown inverted v-shaped mark on the

729 cloacal region of specimen "a". Compare sonograms from specimens “j”" and "l”" in Fig. 2b, c.

730 The presence of yellow spots and $\mathrm{V}$-shaped mark was proposed as diagnostic characteristics to

731 distinguish $B$. sulfuratus from $B$. hermogenesi, but they are variable intraspecifically. For details

732 on geographical localities, see Table 1. Photo credit: Luiz Fernando Ribeiro.

733

734

735 Figure 2. Ventral view of specimens of Brachycephalus sulfuratus (a-c) and B. hermogenesi (d)

736 in preservative, deposited in MHNCI and ZUEC: a) MHNCI 9800 (Salto do Inferno, Paraná); b)

737 MHNCI 10302 (Mananciais da Serra, Paraná); c) MHNCI 10303 (Corvo, Paraná; ex DZUP

738 589); and d) ZUEC 9715 (Núcleo Picinguaba, São Paulo; holotype of B. hermogenesi). Notice

739 the variation in ventral coloration. For details on geographical localities, see Table 1. Photo

740 credit: Luiz Fernando Ribeiro.

741

742

743

Peer) reviewing PDF | (2020:08:52328:1:1:NEW 5 Jan 2021) 
744 Figure 3. Oscillograms (above) and spectrograms (below) of Brachycephalus sulfuratus. A.

745 Example of one entire call with five notes (MHNCI 124; voucher MHNCI 10791 or MHNCI

746 10792; near the Jurupará dam, municipality of Piedade, São Paulo; M. R. Bornschein). B.

747 Example of one entire call with two notes (MHNCI 129; voucher MHNCI 11583; Base of the

748 Serra Água Limpa, municipality of Apiaí, São Paulo; M. R. Bornschein). C. Example of one

749 note with 10 pulses (MHNCI 124). D. Example of one note with three pulses (MHNCI 124).

750 Spectrograms are produced with Hann window, overlap of 50\%, and FFT size of 512 points in A

751 and B and 256 points in C and D. For details on geographical localities, see Table 1.

752

753

754 Figure 4. Oscillograms (above) and spectrograms (below) of Brachycephalus hermogenesi. A.

755 Example of one entire call with 135 notes recorded (MHNCI 165; Corcovado, municipality of

756 Ubatuba, São Paulo; L. F. Ribeiro). B. Example of one isolated note with two pulses (MHNCI

757 183; Núcleo Picinguaba, Parque Estadual da Serra do Mar, municipality of Ubatuba, São Paulo;

758 M. R. Bornschein). C. Example of one note group with three notes (each with two pulses;

759 MHNCI 180; Núcleo Picinguaba; M. R. Bornschein). D. Example of one note group with four

760 notes (each with two pulses; MHNCI 165). E. Example of one note group with three notes (the

761 first with three pulses and the remaining with two pulses; MHNCI 166; Estação Biológica de

762 Boracéia, municipality of Salesópolis, São Paulo; M. R. Bornschein). F. Example of one note

763 group with three notes, with each note preceded by an attenuated note with one pulse (marked

764 with white arrows; MHNCI 183). Spectrograms are produced with Hann window, overlap of

$76550 \%$, and FFT size of 16,384 points in A, 128 points in B, and 256 points in $\mathrm{C}-\mathrm{F}$.

766

767

768 Figure 5. Oscillograms (above) and spectrograms (below) of Brachycephalus sp. (other than $B$.

769 sulfuratus and B. hermogenesi). A. Example of one entire call with 71 notes recorded (MHNCI

770 200; Corcovado, municipality of Ubatuba, São Paulo; M. R. Bornschein). B. Example of one

771 isolated note with seven pulses (MHNCI 198; Corcovado; M. R. Bornschein). C. Example of one

772 note group with two notes (with nine and four pulses, respectively; MHNCI 198). D. Example of

773 one note group with three notes (the first note with three pulses and the remaining notes with

774 four pulses; MHNCI 211; Trilha do Corisco, municipality of Paraty, Rio de Janeiro; L. F. 
775 Ribeiro). Spectrograms are produced with Hann window, overlap of 50\%, and FFT size of

77616,384 points in A and 256 points in B-D.

777

778

779 Figure 6. Current identification of records of flea toads that have been at some point identified as 780 Brachycephalus sulfuratus, B. hermogenesi, and as an unidentified related species, according to 781 the compilation of localities and review of identifications shown in Table 1. We highlighted the 782 southernmost record of $B$. hermogenesi confirmed (1 - Parque Natural Municipal Nascentes de 783 Paranapiacaba). We also highlight the northernmost confirmed records of $B$. sulfuratus (2 784 Núcleo Itutinga-Pilões and 3 - near the Jurupará dam). Abbreviations: RJ = Rio de Janeiro; SP = 785 São Paulo; PR = Paraná; SC = Santa Catarina. Map image is the intellectual property of Esri and 786 is used herein under license. Copyright (C) 2020 Esri and its licensors. All rights reserved.

787

788

789 Figure 7. Phylogenetic tree based on a concatenated dataset of all mitochondrial 12S and 16S 790 mitochondrial loci available on GenBank for specimens of the B. didactylus species group (Table $791 \mathrm{~S} 1)$. The tree was rooted by its midpoint. Whenever possible, the corresponding localities 792 available on their GenBank records were standardized based on the toponyms indicated in Table 793 1. Notice that the specimen originally identified as $B$. hermogenesi from the Municipality of 794 Piedade (Condez, Sawaya \& Dixo 2009, Clemente-Carvalho et al. 2011), was reverted to $B$. 795 sulfuratus (Table 1). Branch values correspond to bootstrap support. 796 797 
799 Appendix 1. Advertisement calls analyzed in the present study. Abbreviation: MHNCI $=$ Museu 800 de História Natural Capão da Imbuia, Curitiba, Paraná.

801

802 Brachycephalus sulfuratus. SÃO PAULO: Base of the Serra Água Limpa, municipality of Apiaí 803 MHNCI 129; Biquinha, municipality of Juquiá MHNCI 128; near the Jurupará dam, 804 municipality of Piedade MHNCI 123-5; Núcleo Itutinga-Pilões, Parque Estadual da Serra do 805 Mar, municipality of Cubatão MHNCI 126-7; Serra do Guaraú, on the border of the 806 municipalities of Cajati and Jacupiranga MHNCI 130; Torre Embratel, municipality of Cajati 807 MHNCI 218. PARANÁ: Caratuval, near the Parque Estadual das Lauráceas, municipality of 808 Adrianópolis MHNCI 131; Caratuval, Parque Estadual das Lauráceas, municipality of 809 Adrianópolis MHNCI 132; Entroncamento Teba, Rio Turvo, municipality of Campina Grande 810 do Sul MHNCI 219; Fazenda Thalia, municipality of Balsa Nova MHNCI 134; Morro do Canal, 811 municipality of Piraquara MHNCI 220; Reserva Particular do Patrimônio Natural Salto Morato, 812 municipality of Guaraqueçaba MHNCI 133. SANTA CATARINA: Monte Crista, municipality 813 of Garuva MHNCI 221; Morro do Garrafão, municipality of Corupá MHNCI 137; Morro 814 Garuva, municipality of Garuva MHNCI 136; Serra do Pico, municipality of Joinville MHNCI 815 217; Truticultura, municipality of Garuva MHNCI 135.

816

817 Brachycephalus hermogenesi. SÃO PAULO: Corcovado, municipality of Ubatuba MHNCI 818 166; Estação Biológica de Boracéia, municipality of Salesópolis MHNCI 166-9; Morro do 819 Cantagalo, municipality of Caraguatatuba MHNCI 222-3; Núcleo Cunha, Parque Estadual da 820 Serra do Mar, municipality of Cunha MHNCI 170-1; Núcleo Picinguaba, Parque Estadual da 821 Serra do Mar, municipality of Ubatuba MHNCI 172-87; Parque Natural Municipal Nascentes de 822 Paranapiacaba, municipality of Santo André MHNCI 213-6; Trilha do Ipiranga $50 \mathrm{~m}$ from the 823 Rio Ipiranga, Núcleo Santa Virgínia, Parque Estadual da Serra do Mar, municipality of São Luiz 824 do Paraitinga MHNCI 188-92.

825

Brachycephalus sp. (other than B. sulfuratus and B. hermogenesi). RIO DE JANEIRO: Trilha 827 do Corisco, municipality of Paraty MHNCI 206-12. SÃO PAULO: Corcovado, municipality of 828 Ubatuba MHNCI 193-205.

829 


\section{Table $\mathbf{1}$ (on next page)}

Current identification of records of flea toads at some point identified as Brachycephalus sulfuratus, $B$. hermogenesi, and as an unidentified related species, southeastern and southern Brazil

Table 1. Current identification of records of flea toads at some point identified as Brachycephalus sulfuratus, $B$. hermogenesi, and as an unidentified related species, southeastern and southern Brazil. Our revision resulted in some unidentified records ( $B$. sulfuratus, $B$. hermogenesi or a third species); the probable identifications are provided below. Localities are in alphabetical order (accordingly to the respective species). Abbreviations: FNJV = Fonoteca Neotropical Jacques Vielliard; $\mathrm{MHNCl}=$ Museu de História Natural Capão da Imbuia, Curitiba, Paraná, Brazil; ZUEC = Museu de História Natural, Universidade Estadual de Campinas, Campinas, state of São Paulo, Brazil; XC = Xeno-Canto sound collection (www.xeno-canto.org). 
Table 1. Current identification of records of flea toads at some point identified as Brachycephalus sulfuratus, B. hermogenesi, and as an unidentified related species, southeastern and southern Brazil. Our revision resulted in some unidentified records (B. sulfuratus, B. hermogenesi or a third species); the probable identifications are provided below. Localities are in alphabetical order (accordingly to the respective species). Abbreviations: FNJV = Fonoteca Neotropical Jacques Vielliard; MHNCI = Museu de História Natural Capão da Imbuia, Curitiba, Paraná, Brazil; ZUEC = Museu de História Natural, Universidade Estadual de Campinas, Campinas, state of São Paulo, Brazil; XC = Xeno-Canto sound collection (www.xeno-canto.org).

\begin{tabular}{|c|c|c|c|c|c|}
\hline Species & Locality and state & $\begin{array}{l}\text { Geographical } \\
\text { coordinates and altitude }\end{array}$ & Previous identification & Voucher & Our analysis of the record \\
\hline \multicolumn{6}{|l|}{ B. sulfuratus } \\
\hline B. sulfuratus & $\begin{array}{l}\text { Bairro Rio Vermelho, } \\
\text { municipality of Barra do } \\
\text { Turvo, São Paulo }\end{array}$ & $\begin{array}{l}24^{\circ} 59^{\prime} 25^{\prime \prime} \mathrm{S}, \\
48^{\circ} 32^{\prime} 26^{\prime \prime} ; 790 \mathrm{~m} \\
\text { a.s.1. }\end{array}$ & --- & Specimen & $\begin{array}{l}\text { Specimen examined } \\
\text { (MHNCI 11584). }\end{array}$ \\
\hline B. sulfuratus & $\begin{array}{l}\text { Base of the Serra Água } \\
\text { Limpa, municipality of } \\
\text { Apiaí, São Paulo }\end{array}$ & $\begin{array}{l}24^{\circ} 28^{\prime} 52^{\prime \prime} \mathrm{S}, \\
48^{\circ} 47^{\prime} 12^{\prime \prime} \mathrm{W} ; 920 \mathrm{~m} \\
\text { a.s.1. }\end{array}$ & $\begin{array}{l}\text { Without species identification: } \\
\text { Firkowski et al. (2016); } \\
\text { Brachycephalus sp. 1: Bornschein et } \\
\text { al. (2016a); B. sulfuratus: } \\
\text { Bornschein et al. (2016b), Ribeiro et } \\
\text { al. (2017), Pie et al. (2018a) }\end{array}$ & $\begin{array}{l}\text { Specimen, calls, } \\
\text { and genetic } \\
\text { sequence on } \\
\text { GenBank }\end{array}$ & $\begin{array}{l}\text { Specimen (MHNCI 11583; } \\
\text { Fig. 1f) and calls examined } \\
\text { (MHNCI 129; Fig. 3B); } \\
\text { KX198030.1 analyzed } \\
\text { sequence (Fig. 7). }\end{array}$ \\
\hline B. sulfuratus & $\begin{array}{l}\text { Biquinha, municipality of } \\
\text { Juquiá, São Paulo }\end{array}$ & $\begin{array}{l}24^{\circ} 17^{\prime} 43^{\prime \prime} \mathrm{S}, \\
47^{\circ} 36^{\prime} 26^{\prime \prime} \mathrm{W} ; 40 \mathrm{~m} \\
\text { a.s.1. }\end{array}$ & $\begin{array}{l}\text { B. sulfuratus: Bornschein, Pie \& } \\
\text { Teixeira (2019a) }\end{array}$ & Calls & $\begin{array}{l}\text { Calls examined (MHNCI } \\
\text { 128). }\end{array}$ \\
\hline B. sulfuratus & $\begin{array}{l}\text { Braço do Norte, } \\
\text { municipality of Itapoá, } \\
\text { Santa Catarina }\end{array}$ & $\begin{array}{l}26^{\circ} 07^{\prime} 29^{\prime \prime} \mathrm{S}, \\
48^{\circ} 43^{\prime} 48^{\prime \prime} \mathrm{W} ; 240 \mathrm{~m} \\
\text { a.s.1. }\end{array}$ & $\begin{array}{l}\text { B. sulfuratus: Monteiro et al. } \\
\text { (2018a) }\end{array}$ & $\begin{array}{l}\text { Specimen and } \\
\text { genetic sequence } \\
\text { on GenBank }\end{array}$ & $\begin{array}{l}\text { MG889430.1 analyzed } \\
\text { sequence (Fig. 7). }\end{array}$ \\
\hline
\end{tabular}




\begin{tabular}{|c|c|c|c|c|c|}
\hline Species & Locality and state & $\begin{array}{l}\text { Geographical } \\
\text { coordinates and altitude }\end{array}$ & Previous identification & Voucher & Our analysis of the record \\
\hline B. sulfuratus & $\begin{array}{l}\text { Caratuval, near the Parque } \\
\text { Estadual das Lauráceas, } \\
\text { municipality of } \\
\text { Adrianópolis, Paraná }\end{array}$ & $\begin{array}{l}24^{\circ} 51^{\prime} 17^{\prime \prime} \mathrm{S}, \\
48^{\circ} 43^{\prime} 43^{\prime} ’ \mathrm{~W} ; 900 \mathrm{~m} \\
\text { a.s.1. }\end{array}$ & $\begin{array}{l}\text { Without species identification: } \\
\text { Firkowski et al. (2016); } \\
\text { Brachycephalus sp. nov. 1: Pie et al. } \\
\text { (2013); Brachycephalus sp. 1: } \\
\text { Bornschein et al. (2016a); B. } \\
\text { sulfuratus: Bornschein et al. } \\
\text { (2016b), Ribeiro et al. (2017), Pie et } \\
\text { al. (2018a) }\end{array}$ & $\begin{array}{l}\text { Specimen, calls, } \\
\text { and genetic } \\
\text { sequence on } \\
\text { GenBank }\end{array}$ & $\begin{array}{l}\text { Specimen (MHNCI 11571; } \\
\text { Fig. 1b) and calls examined } \\
\text { (MHNCI 131); KX198031.1 } \\
\text { analyzed sequence (Fig. 7). }\end{array}$ \\
\hline B. sulfuratus & $\begin{array}{l}\text { Caratuval, Parque Estadual } \\
\text { das Lauráceas, municipality } \\
\text { of Adrianópolis, Paraná }\end{array}$ & $\begin{array}{l}24^{\circ} 51^{\prime} 14^{\prime \prime} \mathrm{S}, \\
48^{\circ} 42^{\prime} 01^{\prime \prime} \mathrm{W} ; 890 \mathrm{~m} \\
\text { a.s.1. }\end{array}$ & $\begin{array}{l}\text { Brachycephalus sp. nov. 1: Pie et al. } \\
\text { (2013); Brachycephalus sp. 1: } \\
\text { Bornschein et al. (2016a) }\end{array}$ & Calls & $\begin{array}{l}\text { Calls examined (MHNCI } \\
132) .\end{array}$ \\
\hline B. sulfuratus & $\begin{array}{l}\text { Castelo dos Bugres, } \\
\text { municipality of Joinville, } \\
\text { Paraná }\end{array}$ & $\begin{array}{l}26^{\circ} 13^{\prime} 47^{\prime \prime} \mathrm{S}, \\
49^{\circ} 03^{\prime} 20^{\prime \prime} \mathrm{W} ; 790-860 \\
\text { m a.s.l. }\end{array}$ & $\begin{array}{l}\text { Brachycephalus sp. nov. 1: Pie et al. } \\
\text { (2013); Brachycephalus sp. 1: } \\
\text { Bornschein et al. (2016a); B. } \\
\text { sulfuratus: Condez et al. (2016), } \\
\text { Monteiro et al. (2018a) }\end{array}$ & $\begin{array}{l}\text { Specimen, calls, } \\
\text { and genetic } \\
\text { sequence on } \\
\text { GenBank }\end{array}$ & $\begin{array}{l}\text { MK697439.1, MK697487.1, } \\
\text { KU321533.1, and } \\
\text { MK697390.1 analyzed } \\
\text { sequence (Fig. 7). }\end{array}$ \\
\hline B. sulfuratus & $\begin{array}{l}\text { Centro de Estudos e } \\
\text { Pesquisas Ambientais da } \\
\text { Univille, Vila da Glória, } \\
\text { Distrito do Saí, } \\
\text { municipality of São }\end{array}$ & $\begin{array}{l}26^{\circ} 13^{\prime} 39^{\prime \prime} \mathrm{S}, \\
48^{\circ} 41^{\prime} 31^{\prime \prime} \mathrm{W} ; 125 \mathrm{~m} \\
\text { a.s.1. }\end{array}$ & B. sulfuratus: Condez et al. (2016) & $\begin{array}{l}\text { Specimen, calls, } \\
\text { and genetics }\end{array}$ & --- \\
\hline
\end{tabular}




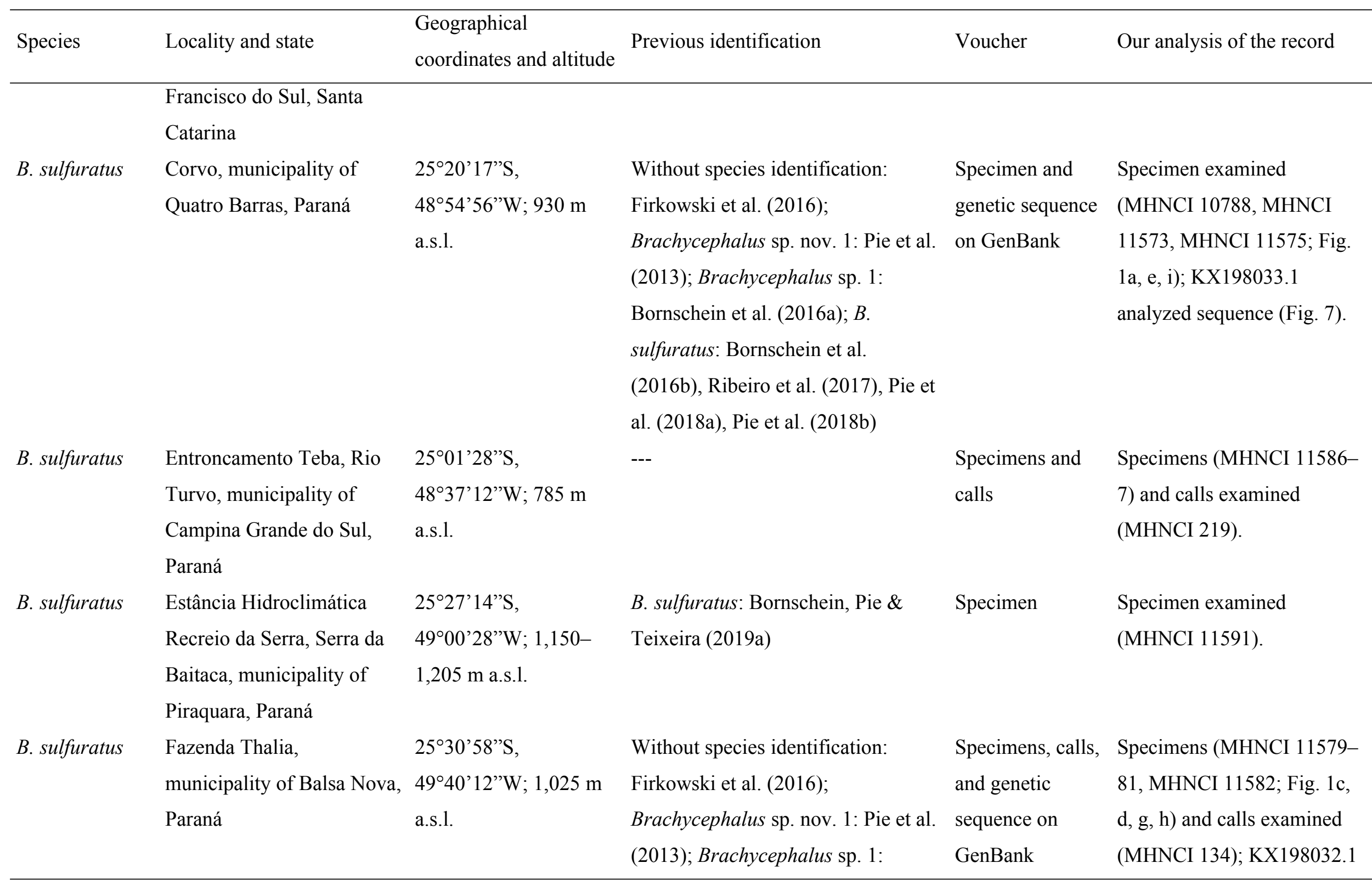




\begin{tabular}{|c|c|c|c|c|c|}
\hline Species & Locality and state & $\begin{array}{l}\text { Geographical } \\
\text { coordinates and altitude }\end{array}$ & Previous identification & Voucher & Our analysis of the record \\
\hline & & & $\begin{array}{l}\text { Bornschein et al. (2016a); B. } \\
\text { sulfuratus: Bornschein et al. } \\
\text { (2016b), Ribeiro et al. (2017), Pie et } \\
\text { al. (2018a) }\end{array}$ & & analyzed sequence (Fig. 7). \\
\hline B. sulfuratus & $\begin{array}{l}\text { near the Jurupará dam, } \\
\text { municipality of Piedade, } \\
\text { São Paulo }\end{array}$ & $\begin{array}{l}23^{\circ} 56^{\prime} 30^{\prime \prime} \mathrm{S}, \\
47^{\circ} 23^{\prime} 45^{\prime \prime} \mathrm{W} ; 690 \mathrm{~m} \\
\text { a.s.l. }\end{array}$ & B. sulfuratus: Pie et al. (2018a) & $\begin{array}{l}\text { Specimens and } \\
\text { calls }\end{array}$ & $\begin{array}{l}\text { Specimens (MHNCI 10790- } \\
\text { 2; Fig. 1j, 1) and calls } \\
\text { examined (MHNCI 123-5; } \\
\text { Fig. 3A, C, D). }\end{array}$ \\
\hline B. sulfuratus & $\begin{array}{l}\text { Mananciais da Serra, } \\
\text { municipality of Piraquara, } \\
\text { Paraná }\end{array}$ & $\begin{array}{l}25^{\circ} 29^{\prime} 32 ” \mathrm{~S}, \\
48^{\circ} 59^{\prime} 33 \text { ' W; } 970- \\
1,050 \mathrm{~m} \text { a.s.1. }\end{array}$ & $\begin{array}{l}\text { Brachycephalus sp. nov. 1: Pie et al. } \\
\text { (2013); Brachycephalus sp. 1: } \\
\text { Bornschein et al. (2016a); B. } \\
\text { sulfuratus: Bornschein et al. } \\
\text { (2016b), Ribeiro et al. (2017), Pie et } \\
\text { al. (2018a) }\end{array}$ & Specimen & $\begin{array}{l}\text { Specimen examined } \\
\text { (MHNCI 10302). }\end{array}$ \\
\hline B. sulfuratus & $\begin{array}{l}\text { Monte Crista, municipality } \\
\text { of Garuva, Santa Catarina }\end{array}$ & $\begin{array}{l}26^{\circ} 04^{\prime} 53^{\prime \prime} \mathrm{S} ; \\
48^{\circ} 55^{\prime} 03^{\prime \prime} \mathrm{W} ; 435 \mathrm{~m} \\
\text { a.s.1. }\end{array}$ & --- & Calls & $\begin{array}{l}\text { Calls examined (MHNCI } \\
\text { 221). }\end{array}$ \\
\hline B. sulfuratus & $\begin{array}{l}\text { Morro Anhangava, } \\
\text { municipality of Quatro } \\
\text { Barras, Paraná }\end{array}$ & $\begin{array}{l}25^{\circ} 22^{\prime} 51^{\prime \prime} \mathrm{S}, \\
49^{\circ} 01^{\prime} 26^{\prime \prime} \mathrm{W} ; 915 \mathrm{~m} \\
\text { a.s.1. }\end{array}$ & $\begin{array}{l}\text { B. sulfuratus: Condez et al. (2016), } \\
\text { Monteiro et al. (2018a) }\end{array}$ & $\begin{array}{l}\text { Specimen and } \\
\text { genetic sequence } \\
\text { on GenBank }\end{array}$ & $\begin{array}{l}\text { MK697488.1, MK697440.1, } \\
\text { KU321534.1, and } \\
\text { MG889428.1 analyzed } \\
\text { sequences (Fig. 7). }\end{array}$ \\
\hline
\end{tabular}




\begin{tabular}{|c|c|c|c|c|c|}
\hline Species & Locality and state & $\begin{array}{l}\text { Geographical } \\
\text { coordinates and altitude }\end{array}$ & Previous identification & Voucher & Our analysis of the record \\
\hline B. sulfuratus & $\begin{array}{l}\text { Morro do Canal, } \\
\text { municipality of Piraquara, } \\
\text { Paraná }\end{array}$ & $\begin{array}{l}25^{\circ} 30^{\prime} 55^{\prime \prime} \mathrm{S} ; \\
48^{\circ} 58^{\prime} 56^{\prime \prime} \mathrm{W} ; 1,315 \mathrm{~m}\end{array}$ & --- & Calls & $\begin{array}{l}\text { Calls examined (MHNCI } \\
\text { 220). }\end{array}$ \\
\hline B. sulfuratus & $\begin{array}{l}\text { Morro do Cantagalo, Vila } \\
\text { da Glória, Distrito do Saí, } \\
\text { municipality of São } \\
\text { Francisco do Sul, Santa } \\
\text { Catarina }\end{array}$ & $\begin{array}{l}26^{\circ} 10^{\prime} 31^{\prime} \mathrm{S}, \\
48^{\circ} 42^{\prime} 44^{\prime} \mathrm{W} ; 160 \mathrm{~m} \\
\text { a.s.1. }\end{array}$ & B. sulfuratus: Condez et al. (2016) & $\begin{array}{l}\text { Specimen and } \\
\text { genetic sequence } \\
\text { on GenBank }\end{array}$ & $\begin{array}{l}\text { MK697441.1, MK697489.1, } \\
\text { KU321532.1, and } \\
\text { MK697392.1 analyzed } \\
\text { sequences (Fig. 7). }\end{array}$ \\
\hline B. sulfuratus & $\begin{array}{l}\text { Morro do Garrafão, } \\
\text { municipality of Corupá, } \\
\text { Santa Catarina }\end{array}$ & $\begin{array}{l}26^{\circ} 28^{\prime} 23 ” \mathrm{~S}, \\
49^{\circ} 15^{\prime} 57^{\prime} \mathrm{W} ; 500-530 \\
\text { m a.s.l. }\end{array}$ & $\begin{array}{l}\text { B. sulfuratus: Pie et al. (2018a), } \\
\text { Teixeira et al. (2018) }\end{array}$ & $\begin{array}{l}\text { Specimen and } \\
\text { calls }\end{array}$ & $\begin{array}{l}\text { Specimens (MHNCI 10826- } \\
\text { 8; Fig. 1k) and calls } \\
\text { examined (MHNCI 137). }\end{array}$ \\
\hline B. sulfuratus & $\begin{array}{l}\text { Morro Garuva, } \\
\text { municipality of Garuva, } \\
\text { Santa Catarina }\end{array}$ & $\begin{array}{l}26^{\circ} 02^{\prime} 29 ” \mathrm{~S}, \\
48^{\circ} 53^{\prime} 14 ’ \mathrm{~W} ; 215-495 \\
\text { m a.s.1. }\end{array}$ & $\begin{array}{l}\text { B. sulfuratus: Bornschein, Pie \& } \\
\text { Teixeira (2019a) }\end{array}$ & Calls & $\begin{array}{l}\text { Calls examined (MHNCI } \\
\text { 136). }\end{array}$ \\
\hline B. sulfuratus & $\begin{array}{l}\text { Municipality of Barra do } \\
\text { Turvo }\end{array}$ & $\begin{array}{l}\text { c. } 24^{\circ} 45^{\prime} \mathrm{S}, 48^{\circ} 29^{\prime} \mathrm{W} \text {; } \\
\text { altitude? }\end{array}$ & B. sulfuratus: GenBank & $\begin{array}{l}\text { Genetic sequence } \\
\text { on GenBank }\end{array}$ & $\begin{array}{l}\text { MK697486.1, MK697438.1, } \\
\text { and MK697389.1 analyzed } \\
\text { sequences (Fig. 7). }\end{array}$ \\
\hline B. sulfuratus & $\begin{array}{l}\text { Municipality of Piedade, } \\
\text { São Paulo }\end{array}$ & $\begin{array}{l}\text { c. } 23^{\circ} 54^{\prime} \mathrm{S}, 47^{\circ} 25^{\prime} \mathrm{W} \\
\text { altitude? }\end{array}$ & $\begin{array}{l}\text { B. hermogenesi: Condez, Sawaya \& } \\
\text { Dixo (2009), Clemente-Carvalho et } \\
\text { al. (2011); Brachycephalus sp. cf. B. } \\
\text { sulfuratus or B. hermogenesi: } \\
\text { Bornschein, Pie \& Teixeira (2019a) }\end{array}$ & $\begin{array}{l}\text { Specimen and } \\
\text { genetic sequence } \\
\text { on GenBank }\end{array}$ & $\begin{array}{l}\text { HQ435682.1 and } \\
\text { HQ435709.1 analyzed } \\
\text { sequences (Fig. 7). }\end{array}$ \\
\hline
\end{tabular}




\begin{tabular}{|c|c|c|c|c|c|}
\hline Species & Locality and state & $\begin{array}{l}\text { Geographical } \\
\text { coordinates and altitude }\end{array}$ & Previous identification & Voucher & Our analysis of the record \\
\hline B. sulfuratus & $\begin{array}{l}\text { Núcleo Itutinga-Pilões, } \\
\text { Parque Estadual da Serra do } \\
\text { Mar, municipality of } \\
\text { Cubatão, São Paulo }\end{array}$ & $\begin{array}{l}23^{\circ} 54^{\prime} 17^{\prime \prime} \mathrm{S}, \\
46^{\circ} 29^{\prime} 22^{\prime \prime} \mathrm{W} ; 55 \mathrm{~m} \\
\text { a.s.1. }\end{array}$ & $\begin{array}{l}\text { B. sulfuratus: Bornschein, Pie \& } \\
\text { Teixeira (2019a) }\end{array}$ & Calls & $\begin{array}{l}\text { Calls examined (MHNCI } \\
126-7) .\end{array}$ \\
\hline B. sulfuratus & $\begin{array}{l}\text { Parque Estadual da Ilha do } \\
\text { Cardoso, municipality of } \\
\text { Cananéia, São Paulo }\end{array}$ & $\begin{array}{l}25^{\circ} 06^{\prime} 53^{\prime} \mathrm{S}, \\
47^{\circ} 55^{\prime} 40^{\prime} \mathrm{W} ; 385 \mathrm{~m} \\
\text { a.s.1. }\end{array}$ & $\begin{array}{l}\text { Possibly B. hermogenesi: Verdade et } \\
\text { al. (2008); B. sulfuratus: Condez et } \\
\text { al. (2016) }\end{array}$ & $\begin{array}{l}\text { Specimen, calls, } \\
\text { and genetic } \\
\text { sequence on } \\
\text { GenBank }\end{array}$ & $\begin{array}{l}\text { MK697485.1, MK697437.1, } \\
\text { KU321535.1, and } \\
\text { MK697388.1 analyzed } \\
\text { sequences (Fig. 7). }\end{array}$ \\
\hline B. sulfuratus & $\begin{array}{l}\text { Parque Estadual Intervales, } \\
\text { municipality of Iporanga, } \\
\text { São Paulo }\end{array}$ & $\begin{array}{l}24^{\circ} 16^{\prime} 33^{\prime \prime} \mathrm{S}, \\
48^{\circ} 25^{\prime} 04^{\prime \prime} \mathrm{W} ; 820 \mathrm{~m} \\
\text { a.s.1. }\end{array}$ & $\begin{array}{l}\text { B. sulfuratus: Bornschein, Pie \& } \\
\text { Teixeira (2019a) }\end{array}$ & Calls & $\begin{array}{l}\text { Calls examined (XC80463 } \\
\text { XC18179, XC75544). }\end{array}$ \\
\hline B. sulfuratus & $\begin{array}{l}\text { Pedra da Tartaruga, } \\
\text { municipality of Garuva, } \\
\text { Santa Catarina }\end{array}$ & $\begin{array}{l}25^{\circ} 59^{\prime} 42^{\prime} \mathrm{S}, \\
48^{\circ} 54^{\prime} 23^{\prime} \mathrm{W} ; 465 \mathrm{~m} \\
\text { a.s.1. }\end{array}$ & --- & Specimen & $\begin{array}{l}\text { Specimen examined } \\
\text { (MHNCI 11585). }\end{array}$ \\
\hline B. sulfuratus & $\begin{array}{l}\text { Pico Marumbi, Parque } \\
\text { Estadual do Pico Marumbi, } \\
\text { municipality of Morretes, } \\
\text { Paraná }\end{array}$ & $\begin{array}{l}25^{\circ} 27^{\prime} 03^{\prime \prime} \mathrm{S} ; \\
48^{\circ} 54^{\prime} 59^{\prime \prime} \mathrm{W} ; 1180 \mathrm{~m} \\
\text { a.s.1. }\end{array}$ & --- & Specimen & $\begin{array}{l}\text { Specimen examined } \\
\text { (MHNCI 10302). }\end{array}$ \\
\hline B. sulfuratus & $\begin{array}{l}\text { Recanto das Hortências, } \\
\text { municipality of São José } \\
\text { dos Pinhais, Paraná }\end{array}$ & $\begin{array}{l}25^{\circ} 33^{\prime} 24^{\prime \prime} \mathrm{S}, \\
48^{\circ} 59^{\prime} 38^{\prime \prime} \mathrm{W} ; 975 \mathrm{~m} \\
\text { a.s.1. }\end{array}$ & $\begin{array}{l}\text { Brachycephalus sp. 1: Bornschein et } \\
\text { al. (2016a); B. sulfuratus: Ribeiro et } \\
\text { al. (2017), Bornschein et al. (2016b), } \\
\text { Pie et al. (2018a) }\end{array}$ & Specimen & Specimen examined. \\
\hline
\end{tabular}




\begin{tabular}{|c|c|c|c|c|c|}
\hline Species & Locality and state & $\begin{array}{l}\text { Geographical } \\
\text { coordinates and altitude }\end{array}$ & Previous identification & Voucher & Our analysis of the record \\
\hline B. sulfuratus & $\begin{array}{l}\text { Reserva Particular do } \\
\text { Patrimônio Natural Salto } \\
\text { Morato, municipality of } \\
\text { Guaraqueçaba, Paraná }\end{array}$ & $\begin{array}{l}25^{\circ} 09^{\prime} 14^{\prime \prime} \mathrm{S}, \\
48^{\circ} 18^{\prime} 06^{\prime \prime} \mathrm{W} ; 40-880 \\
\text { m a.s.l. }\end{array}$ & $\begin{array}{l}\text { B. hermogenesi: Pereira et al. } \\
\text { (2010), Santos-Pereira et al. (2011, } \\
\text { 2016, 2018), Leivas et al. (2018); } \\
\text { Brachycephalus sp. 1: Bornschein et } \\
\text { al. (2016a) }\end{array}$ & $\begin{array}{l}\text { Specimen and } \\
\text { calls }\end{array}$ & $\begin{array}{l}\text { Calls examined (MHNCI } \\
\text { 133). }\end{array}$ \\
\hline B. sulfuratus & $\begin{array}{l}\text { Salto do Inferno, Rio } \\
\text { Capivari, municipality of } \\
\text { Bocaiúva do Sul, Paraná }\end{array}$ & $\begin{array}{l}25^{\circ} 00^{\prime} 02^{\prime} \mathrm{S}, \\
48^{\circ} 37^{\prime} 07^{\prime \prime} \mathrm{W} ; 610 \mathrm{~m} \\
\text { a.s.l. }\end{array}$ & $\begin{array}{l}\text { B. sulfuratus: Ribeiro et al. (2017), } \\
\text { Bornschein et al. (2016b), Pie et al. } \\
\text { (2018a) }\end{array}$ & Specimen & Specimen examined. \\
\hline B. sulfuratus & $\begin{array}{l}\text { Serra do Guaraú, on the } \\
\text { border of the municipalities } \\
\text { of Cajati and Jacupiranga, } \\
\text { São Paulo }\end{array}$ & $\begin{array}{l}24^{\circ} 47^{\prime} 12^{\prime \prime} \mathrm{S}, \\
48^{\circ} 07^{\prime} 11^{\prime \prime W} ; 680-835 \\
\text { m a.s.l. }\end{array}$ & $\begin{array}{l}\text { B. sulfuratus: Bornschein, Pie \& } \\
\text { Teixeira (2019a) }\end{array}$ & Calls & $\begin{array}{l}\text { Calls examined (MHNCI } \\
130) .\end{array}$ \\
\hline B. sulfuratus & $\begin{array}{l}\text { Serra do Pico, municipality } \\
\text { of Joinville, Santa Catarina }\end{array}$ & $\begin{array}{l}26^{\circ} 08^{\prime} 31 ’ \mathrm{~S}, \\
48^{\circ} 57^{\prime} 19^{\prime \prime} \mathrm{W} ; 340-720 \\
\text { m a.s.l. }\end{array}$ & $\begin{array}{l}\text { B. sulfuratus: Bornschein, Pie \& } \\
\text { Teixeira (2019a) }\end{array}$ & Calls & $\begin{array}{l}\text { Calls examined (MHNCI } \\
\text { 217). }\end{array}$ \\
\hline B. sulfuratus & $\begin{array}{l}\text { Torre Embratel, } \\
\text { municipality of Cajati, São } \\
\text { Paulo }\end{array}$ & $\begin{array}{l}24^{\circ} 52^{\prime} 46^{\prime \prime} \mathrm{S}, \\
48^{\circ} 15^{\prime} 27^{\prime} \mathrm{W} ; 960-990 \\
\text { m a.s.1. }\end{array}$ & $\begin{array}{l}\text { B. sulfuratus: Bornschein, Pie \& } \\
\text { Teixeira (2019a) }\end{array}$ & $\begin{array}{l}\text { Specimen and } \\
\text { calls }\end{array}$ & $\begin{array}{l}\text { Specimen (MHNCI 11588) } \\
\text { and calls examined (MHNCI } \\
218) \text {. }\end{array}$ \\
\hline B. sulfuratus & $\begin{array}{l}\text { Truticultura, municipality } \\
\text { of Garuva, Paraná }\end{array}$ & $\begin{array}{l}26^{\circ} 01^{\prime} 33 ” \mathrm{~S}, \\
48^{\circ} 52^{\prime} 02^{\prime \prime} \mathrm{W} ; 90 \mathrm{~m} \\
\text { a.s.1. }\end{array}$ & $\begin{array}{l}\text { Brachycephalus sp. nov. 1: Pie et al. } \\
\text { (2013); Brachycephalus sp. 1: } \\
\text { Bornschein et al. (2016a); B. } \\
\text { sulfuratus: Bornschein, Pie \& }\end{array}$ & Calls & $\begin{array}{l}\text { Calls examined (MHNCI } \\
\text { 135). }\end{array}$ \\
\hline
\end{tabular}




\begin{tabular}{|c|c|c|c|c|c|}
\hline Species & Locality and state & $\begin{array}{l}\text { Geographical } \\
\text { coordinates and altitude }\end{array}$ & Previous identification & Voucher & Our analysis of the record \\
\hline \multicolumn{6}{|c|}{ Teixeira (2019a) } \\
\hline \multicolumn{6}{|l|}{ B. hermogenesi } \\
\hline B. hermogenesi & $\begin{array}{l}\text { Corcovado, municipality of } \\
\text { Ubatuba, São Paulo }\end{array}$ & $\begin{array}{l}23^{\circ} 28^{\prime} 20 ” S, \\
45^{\circ} 11^{\prime} 41^{\prime \prime}, \mathrm{W} ; 30-250 \\
\text { m a.s.1. }\end{array}$ & $\begin{array}{l}\text { B. hermogenesi: Bornschein, Pie \& } \\
\text { Teixeira (2019a; in part.) }\end{array}$ & Calls & $\begin{array}{l}\text { Calls examined (MHNCI } \\
\text { 166; Fig. 4A, D). }\end{array}$ \\
\hline B. hermogenesi & $\begin{array}{l}\text { Estação Biológica de } \\
\text { Boracéia, municipality of } \\
\text { Salesópolis, São Paulo }\end{array}$ & $\begin{array}{l}23^{\circ} 39^{\prime} 10^{\prime} \mathrm{S}, \\
45^{\circ} 53^{\prime} 05^{\prime} \mathrm{W} ; 825-900 \\
\text { m a.s.1. }\end{array}$ & $\begin{array}{l}\text { B. hermogenesi: Pimenta et al. } \\
\text { (2007), Verdade et al. (2008), Pie et } \\
\text { al. (2013), Bornschein et al. (2016a), } \\
\text { Condez et al. (2016) }\end{array}$ & $\begin{array}{l}\text { Specimens and } \\
\text { calls }\end{array}$ & $\begin{array}{l}\text { Specimens (MHNCI, one } \\
\text { uncatalogued specimen) and } \\
\text { calls examined (MHNCI } \\
\text { 166-9; Fig. 4E), including } \\
\text { recordings sent by V. K. } \\
\text { Verdade. }\end{array}$ \\
\hline B. hermogenesi & $\begin{array}{l}\text { Fazenda Capricórnio, } \\
\text { municipality of Ubatuba, } \\
\text { São Paulo }\end{array}$ & $\begin{array}{l}23^{\circ} 23^{\prime} 27^{\prime \prime} \mathrm{S}, \\
45^{\circ} 04^{\prime} 26 ” \mathrm{~W} ; 60 \mathrm{~m} \\
\text { a.s.1. }\end{array}$ & $\begin{array}{l}\text { B. hermogenesi: Giaretta and } \\
\text { Sawaya (1998), Verdade et al. } \\
\text { (2008), Pie et al. (2013), Bornschein } \\
\text { et al. (2016a), Condez et al. (2016) }\end{array}$ & $\begin{array}{l}\text { Specimens } \\
\text { (paratypes) }\end{array}$ & $\begin{array}{l}\text { Specimen examined (ZUEC } \\
\text { 9725). }\end{array}$ \\
\hline B. hermogenesi & $\begin{array}{l}\text { Morro do Cantagalo, } \\
\text { municipality of } \\
\text { Caraguatatuba, São Paulo }\end{array}$ & $\begin{array}{l}23^{\circ} 36^{\prime} 23 ” S, \\
45^{\circ} 23 ’ 34 ” W ; 155-195 \\
\text { m a.s.l. }\end{array}$ & --- & Calls & $\begin{array}{l}\text { Calls examined (MHNCI } \\
222-3) \text {. }\end{array}$ \\
\hline B. hermogenesi & $\begin{array}{l}\text { Municipality of Paraibuna, } \\
\text { São Paulo }\end{array}$ & $\begin{array}{l}\text { c. } 23^{\circ} 23^{\prime} 34^{\prime \prime} \mathrm{S}, \\
45^{\circ} 39^{\prime} 42^{\prime \prime} \mathrm{W} \text {; altitude? }\end{array}$ & $\begin{array}{l}\text { B. hermogenesi: Condez et al. } \\
\text { (2016) }\end{array}$ & $\begin{array}{l}\text { Specimen and } \\
\text { genetic sequence } \\
\text { on GenBank }\end{array}$ & $\begin{array}{l}\text { MK697373.1 analyzed } \\
\text { sequence (Fig. 7). }\end{array}$ \\
\hline B. hermogenesi & Núcleo Cunha, Parque & $23^{\circ} 15^{\prime} 48^{\prime \prime} \mathrm{S}$ & B. hermogenesi: Bornschein, Pie \& & Specimen and & Specimen (MHNCI, one \\
\hline
\end{tabular}




\begin{tabular}{|c|c|c|c|c|c|}
\hline Species & Locality and state & $\begin{array}{l}\text { Geographical } \\
\text { coordinates and altitude }\end{array}$ & Previous identification & Voucher & Our analysis of the record \\
\hline & $\begin{array}{l}\text { Estadual da Serra do Mar, } \\
\text { municipality of Cunha, São } \\
\text { Paulo }\end{array}$ & $\begin{array}{l}45^{\circ} 02^{\prime} 39^{\prime \prime} \mathrm{W} ; 1,045- \\
1,140 \mathrm{~m} \text { a.s.1. }\end{array}$ & Teixeira (2019a) & calls & $\begin{array}{l}\text { uncatalogued specimen) and } \\
\text { calls examined (MHNCI } \\
170-1) \text {. }\end{array}$ \\
\hline B. hermogenesi & $\begin{array}{l}\text { Núcleo Picinguaba, Parque } \\
\text { Estadual da Serra do Mar, } \\
\text { municipality of Ubatuba, } \\
\text { São Paulo }\end{array}$ & $\begin{array}{l}23^{\circ} 22^{\prime} 21 ” \mathrm{~s}, \\
44^{\circ} 49^{\prime} 53 ” \mathrm{~W} ; 0-700 \mathrm{~m} \\
\text { a.s.1. }\end{array}$ & $\begin{array}{l}\text { B. hermogenesi: Giaretta and } \\
\text { Sawaya (1998), Pimenta et al. } \\
\text { (2007), Verdade et al. (2008), } \\
\text { Clemente-Carvalho et al. (2009), Pie } \\
\text { et al. (2013), Bornschein et al. } \\
\text { (2016a), Condez et al. (2016), Pie et } \\
\text { al. (2018a) }\end{array}$ & $\begin{array}{l}\text { Specimens } \\
\text { (holotype and } \\
\text { paratypes), calls, } \\
\text { and genetic } \\
\text { sequence on } \\
\text { GenBank }\end{array}$ & $\begin{array}{l}\text { Specimens (ZUEC 9715-21; } \\
\text { Fig. 3d) and calls examined } \\
\text { (MHNCI 172-87; Fig. 4B, C, } \\
\text { F); MK697472.1, } \\
\text { KU321531.1, and } \\
\text { MK697374.1 analyzed } \\
\text { sequences (Fig. 7). }\end{array}$ \\
\hline B. hermogenesi & $\begin{array}{l}\text { Núcleo Santa Virgínea, } \\
\text { Parque Estadual da Serra do } \\
\text { Mar, municipality of São } \\
\text { Luiz do Paraitinga, São } \\
\text { Paulo }\end{array}$ & $\begin{array}{l}23^{\circ} 19^{\prime} 36^{\prime} \mathrm{S}, \\
45^{\circ} 07^{\prime} 57^{\prime} \mathrm{W} ; 915 \mathrm{~m} \\
\text { a.s.l. }\end{array}$ & --- & Calls & Calls examined (XC253045). \\
\hline B. hermogenesi & $\begin{array}{l}\text { Parque Natural Municipal } \\
\text { Nascentes de } \\
\text { Paranapiacaba, } \\
\text { municipality of Santo } \\
\text { André, São Paulo }\end{array}$ & $\begin{array}{l}23^{\circ} 46^{\prime} 10^{\prime} \mathrm{S}, \\
46^{\circ} 17^{\prime} 36^{\prime} \mathrm{W} ; 840 \mathrm{~m} \\
\text { a.s.1. }\end{array}$ & $\begin{array}{l}\text { B. hermogenesi: Verdade, Rodrigues } \\
\text { \& Pavan (2009); Brachycephalus sp. } \\
\text { cf. B. sulfuratus or B. hermogenesi: } \\
\text { Bornschein, Pie \& Teixeira (2019a) }\end{array}$ & Calls & $\begin{array}{l}\text { Calls examined (MHNCI } \\
213-6) \text {. }\end{array}$ \\
\hline B. hermogenesi & $\begin{array}{l}\text { Sertão da Cutia, } \\
\text { municipality of Ubatuba, }\end{array}$ & not located & $\begin{array}{l}\text { B. hermogenesi: Condez et al. } \\
\text { (2016) }\end{array}$ & Specimen & --- \\
\hline
\end{tabular}




\begin{tabular}{|c|c|c|c|c|c|}
\hline Species & Locality and state & $\begin{array}{l}\text { Geographical } \\
\text { coordinates and altitude }\end{array}$ & Previous identification & Voucher & Our analysis of the record \\
\hline B. hermogenesi & $\begin{array}{l}\text { So Paulo } \\
\text { Trilha do Ipiranga } 50 \mathrm{~m} \\
\text { from the Rio Ipiranga, } \\
\text { Núcleo Santa Virgínia, } \\
\text { Parque Estadual da Serra do } \\
\text { Mar, municipality of São } \\
\text { Luiz do Paraitinga, São } \\
\text { Paulo }\end{array}$ & $\begin{array}{l}23^{\circ} 20^{\prime} 41^{\prime \prime} \mathrm{S}, \\
45^{\circ} 08^{\prime} 21^{\prime \prime} \mathrm{W} ; 920-940 \\
\text { m a.s.1. }\end{array}$ & $\begin{array}{l}\text { B. hermogenesi: Bornschein, Pie \& } \\
\text { Teixeira (2019a) }\end{array}$ & Calls & $\begin{array}{l}\text { Calls examined (MHNCI } \\
\text { 188-92). }\end{array}$ \\
\hline \multicolumn{6}{|c|}{ Brachycephalus sp. (other than B. sulfuratus and B. hermogenesi) } \\
\hline $\begin{array}{l}\text { Brachycephalus } \\
\text { sp. }\end{array}$ & $\begin{array}{l}\text { Corcovado, municipality of } \\
\text { Ubatuba, São Paulo }\end{array}$ & $\begin{array}{l}23^{\circ} 28 ’ 20 ” \mathrm{~S}, \\
45^{\circ} 11^{\prime} 41 ’ \mathrm{~W} ; 30-250 \\
\text { m a.s.l. }\end{array}$ & $\begin{array}{l}\text { B. hermogenesi: Giaretta and } \\
\text { Sawaya (1998), Verdade et al. } \\
\text { (2008), Pie et al. (2013), Bornschein } \\
\text { et al. (2016a), Pie et al. (2018a; } \\
\text { collected at "Picinguaba" [= } \\
\text { Corcovado]), Bornschein, Pie \& } \\
\text { Teixeira (2019a; in part.) }\end{array}$ & $\begin{array}{l}\text { Specimens } \\
\text { (including } \\
\text { paratypes) and } \\
\text { calls }\end{array}$ & $\begin{array}{l}\text { Specimens (ZUEC 9722-4, } \\
\text { MHNCI 10823-5) and calls } \\
\text { examined (MHNCI 193-205; } \\
\text { Fig. 5A-C). }\end{array}$ \\
\hline $\begin{array}{l}\text { Brachycephalus } \\
\text { sp. }\end{array}$ & $\begin{array}{l}\text { Trilha do Corisco, } \\
\text { municipality of Paraty, Rio } \\
\text { de Janeiro }\end{array}$ & $\begin{array}{l}23^{\circ} 16^{\prime} 38^{\prime \prime} \mathrm{S}, \\
44^{\circ} 46^{\prime} 39^{\prime \prime} \mathrm{W} ; 350-725 \\
\text { m a.s.1. }\end{array}$ & $\begin{array}{l}\text { B. hermogenesi: Bornschein, Pie \& } \\
\text { Teixeira (2019a) }\end{array}$ & Calls & $\begin{array}{l}\text { Calls examined (MHNCI } \\
\text { 206-12; Fig. 5D). }\end{array}$ \\
\hline \multicolumn{6}{|c|}{ Brachycephalus sp. (B. hermogenesi or B. sulfuratus) } \\
\hline $\begin{array}{l}\text { Brachycephalus } \\
\text { sp. }\end{array}$ & $\begin{array}{l}\text { Alto Quiriri, municipality } \\
\text { of Garuva, Santa Catarina }\end{array}$ & $\begin{array}{l}26^{\circ} 05^{\prime} 34^{\prime \prime}, \\
48^{\circ} 59^{\prime} 41^{\prime \prime W} ; 240 \mathrm{~m}\end{array}$ & $\begin{array}{l}\text { Brachycephalus sp. nov. 1: Pie et al. } \\
\text { (2013); Brachycephalus sp. 1: }\end{array}$ & Unvouchered & $\begin{array}{l}\text { The calls resemble those of } \\
\text { B. sulfuratus (auditory record }\end{array}$ \\
\hline
\end{tabular}




\begin{tabular}{|c|c|c|c|c|c|}
\hline Species & Locality and state & $\begin{array}{l}\text { Geographical } \\
\text { coordinates and altitude }\end{array}$ & Previous identification & Voucher & Our analysis of the record \\
\hline & & a.s.l. & $\begin{array}{l}\text { Bornschein et al. (2016a); } \\
\text { Brachycephalus sp. cf. B. sulfuratus: } \\
\text { Bornschein, Pie \& Teixeira (2019a) }\end{array}$ & & made by MRB). \\
\hline $\begin{array}{l}\text { Brachycephalus } \\
\text { sp. }\end{array}$ & $\begin{array}{l}\text { Colônia Castelhanos, } \\
\text { municipality of Guaratuba, } \\
\text { Paraná }\end{array}$ & $\begin{array}{l}25^{\circ} 47^{\prime} 58^{\prime} \mathrm{S}, \\
48^{\circ} 54^{\prime} 40^{\prime} \mathrm{W} ; 290 \mathrm{~m} \\
\text { a.s.l. }\end{array}$ & $\begin{array}{l}\text { Brachycephalus aff. hermogenesi: } \\
\text { Cunha et al. (2010); B. hermogenesi } \\
\text { Oliveira et al. (2011); } \\
\text { Brachycephalus sp. nov. 1: Pie et al. } \\
\text { (2013); Brachycephalus sp. 1: } \\
\text { Bornschein et al. (2016a); B. } \\
\text { sulfuratus: Condez et al. (2016); } \\
\text { Brachycephalus sp. cf. B. sulfuratus: } \\
\text { Bornschein, Pie \& Teixeira (2019a) }\end{array}$ & Specimen & $\begin{array}{l}\text { Specimen examined (ZUEC } \\
\text { 16602). }\end{array}$ \\
\hline $\begin{array}{l}\text { Brachycephalus } \\
\text { sp. }\end{array}$ & $\begin{array}{l}\text { Dona Francisca, } \\
\text { municipality of Joinville, } \\
\text { Santa Catarina }\end{array}$ & $\begin{array}{l}26^{\circ} 09^{\prime} 52^{\prime} \mathrm{S}, \\
48^{\circ} 59^{\prime} 23^{\prime} \mathrm{W} ; 150 \mathrm{~m} \\
\text { a.s.1. }\end{array}$ & $\begin{array}{l}\text { Brachycephalus sp. nov. 1: Pie et al. } \\
\text { (2013); Brachycephalus sp. 1: } \\
\text { Bornschein et al. (2016a); } \\
\text { Brachycephalus sp. cf. B. sulfuratus: } \\
\text { Bornschein, Pie \& Teixeira (2019a) }\end{array}$ & Unvouchered & $\begin{array}{l}\text { The calls resemble those of } \\
\text { B. sulfuratus (auditory record } \\
\text { made by MRB). }\end{array}$ \\
\hline $\begin{array}{l}\text { Brachycephalus } \\
\text { sp. }\end{array}$ & $\begin{array}{l}\text { Estação Ecológica Juréia- } \\
\text { Itatins, municipality of } \\
\text { Iguape, São Paulo }\end{array}$ & $\begin{array}{l}\text { c. } 24^{\circ} 27^{\prime} \mathrm{S}, 47^{\circ} 24^{\prime} \mathrm{W} \text {; } \\
\text { altitude? }\end{array}$ & $\begin{array}{l}\text { B. hermogenesi: Verdade et al. } \\
\text { (2008); Brachycephalus sp. cf. B. } \\
\text { sulfuratus or B. hermogenesi: } \\
\text { Bornschein, Pie \& Teixeira (2019a) }\end{array}$ & Specimen & --- \\
\hline Brachycephalus & Estrada do Rio do Júlio, & $26^{\circ} 17^{\prime} 02{ }^{\prime} \mathrm{S}$ & Brachycephalus sp.: Mariotto & Specimen & --- \\
\hline
\end{tabular}




\begin{tabular}{|c|c|c|c|c|c|}
\hline Species & Locality and state & $\begin{array}{l}\text { Geographical } \\
\text { coordinates and altitude }\end{array}$ & Previous identification & Voucher & Our analysis of the record \\
\hline sp. & $\begin{array}{l}\text { municipality of Joinville, } \\
\text { Santa Catarina }\end{array}$ & $\begin{array}{l}49^{\circ} 06^{\prime} 08^{\prime} \mathrm{W} ; 650 \mathrm{~m} \\
\text { a.s.l. }\end{array}$ & $\begin{array}{l}\text { (2014); Brachycephalus sp. 1: } \\
\text { Bornschein et al. (2016a); } \\
\text { Brachycephalus sp. cf. B. sulfuratus: } \\
\text { Bornschein, Pie \& Teixeira (2019a) }\end{array}$ & & \\
\hline $\begin{array}{l}\text { Brachycephalus } \\
\text { sp. }\end{array}$ & $\begin{array}{l}\text { Fazenda Pico Paraná, } \\
\text { municipality of Campina } \\
\text { Grande do Sul, Paraná }\end{array}$ & $\begin{array}{l}25^{\circ} 13^{\prime} 29^{\prime \prime} \mathrm{S}, \\
48^{\circ} 51^{\prime} 17^{\prime \prime} \mathrm{W} ; 1,050- \\
1,085 \text { m a.s.l. }\end{array}$ & $\begin{array}{l}\text { Brachycephalus sp. nov. 1: Pie et al. } \\
\text { (2013); Brachycephalus sp. 1: } \\
\text { Bornschein et al. (2016a); } \\
\text { Brachycephalus sp. cf. B. sulfuratus: } \\
\text { Bornschein, Pie \& Teixeira (2019a) }\end{array}$ & Unvouchered & $\begin{array}{l}\text { The calls resemble those of } \\
\text { B. sulfuratus (auditory } \\
\text { records made by MRB and } \\
\text { LFR). }\end{array}$ \\
\hline $\begin{array}{l}\text { Brachycephalus } \\
\text { sp. }\end{array}$ & $\begin{array}{l}\text { Fazenda Primavera, } \\
\text { municipality of Tunas do } \\
\text { Paraná, Paraná }\end{array}$ & $\begin{array}{l}24^{\circ} 53 \text { '08'S, } \\
48^{\circ} 45^{\prime} 51 \text { ' } \mathrm{W} ; 1,060 \mathrm{~m} \\
\text { a.s.1. }\end{array}$ & $\begin{array}{l}\text { Brachycephalus sp. nov. 1: Pie et al. } \\
\text { (2013); Brachycephalus sp. 1: } \\
\text { Bornschein et al. (2016a); } \\
\text { Brachycephalus sp. cf. B. sulfuratus: } \\
\text { Bornschein, Pie \& Teixeira (2019a) }\end{array}$ & Unvouchered & $\begin{array}{l}\text { The calls resemble those of } \\
\text { B. sulfuratus (auditory record } \\
\text { made by MRB). }\end{array}$ \\
\hline $\begin{array}{l}\text { Brachycephalus } \\
\text { sp. }\end{array}$ & $\begin{array}{l}\text { Municipality of Ibiúna, São } \\
\text { Paulo }\end{array}$ & $\begin{array}{l}\text { c. } 23^{\circ} 39^{\prime} \mathrm{S}, 47^{\circ} 13^{\prime} \mathrm{W} \text {; } \\
\text { altitude? }\end{array}$ & $\begin{array}{l}\text { B. hermogenesi: Condez et al. } \\
\text { (2016); Brachycephalus sp. cf. B. } \\
\text { sulfuratus or B. hermogenesi: } \\
\text { Bornschein, Pie \& Teixeira (2019a) }\end{array}$ & Specimen & --- \\
\hline $\begin{array}{l}\text { Brachycephalus } \\
\text { sp. }\end{array}$ & $\begin{array}{l}\text { Municipality of Juquitiba, } \\
\text { São Paulo }\end{array}$ & $\begin{array}{l}\text { c. } 23^{\circ} 56^{\prime} \mathrm{S}, 47^{\circ} 04^{\prime} \mathrm{W} ; \\
\text { altitude? }\end{array}$ & $\begin{array}{l}\text { B. hermogenesi: Verdade et al. } \\
\text { (2008), Condez et al. (2016); } \\
\text { Brachycephalus sp. cf. B. sulfuratus } \\
\text { or B. hermogenesi: Bornschein, Pie }\end{array}$ & Specimen & --- \\
\hline
\end{tabular}




\begin{tabular}{|c|c|c|c|c|c|}
\hline Species & Locality and state & $\begin{array}{l}\text { Geographical } \\
\text { coordinates and altitude }\end{array}$ & Previous identification & Voucher & Our analysis of the record \\
\hline & & & \& Teixeira (2019a) & & \\
\hline $\begin{array}{l}\text { Brachycephalus } \\
\text { sp. }\end{array}$ & $\begin{array}{l}\text { Municipality of Peruíbe, } \\
\text { São Paulo }\end{array}$ & $\begin{array}{l}24^{\circ} 18^{\prime} \mathrm{S}, 46^{\circ} 59^{\prime} \mathrm{W} ; \\
\text { altitude? }\end{array}$ & $\begin{array}{l}\text { B. hermogenesi: Condez et al. } \\
\text { (2016); Brachycephalus sp. cf. B. } \\
\text { sulfuratus or B. hermogenesi: } \\
\text { Bornschein, Pie \& Teixeira (2019a) }\end{array}$ & Specimen & --- \\
\hline $\begin{array}{l}\text { Brachycephalus } \\
\text { sp. }\end{array}$ & $\begin{array}{l}\text { Municipality of Registro, } \\
\text { São Paulo }\end{array}$ & $\begin{array}{l}\text { c. } 24^{\circ} 30^{\prime} \mathrm{S}, 47^{\circ} 51^{\prime} \mathrm{W} \text {; } \\
\text { altitude? }\end{array}$ & $\begin{array}{l}\text { B. hermogenesi: Condez et al. } \\
\text { (2016); Brachycephalus sp. cf. B. } \\
\text { sulfuratus or B. hermogenesi: } \\
\text { Bornschein, Pie \& Teixeira (2019a) }\end{array}$ & Specimen & --- \\
\hline $\begin{array}{l}\text { Brachycephalus } \\
\text { sp. }\end{array}$ & $\begin{array}{l}\text { Municipality of Ribeirão } \\
\text { Grande, São Paulo }\end{array}$ & $\begin{array}{l}\text { c. } 24^{\circ} 06^{\prime} \mathrm{S}, 48^{\circ} 22^{\prime} \mathrm{W} \text {; } \\
\text { altitude? }\end{array}$ & $\begin{array}{l}\text { B. hermogenesi: Verdade et al. } \\
\text { (2008); Brachycephalus sp. cf. B. } \\
\text { sulfuratus or B. hermogenesi: } \\
\text { Bornschein, Pie \& Teixeira (2019a) }\end{array}$ & Specimen & --- \\
\hline $\begin{array}{l}\text { Brachycephalus } \\
\text { sp. }\end{array}$ & $\begin{array}{l}\text { Municipality of Tapiraí, } \\
\text { São Paulo }\end{array}$ & $\begin{array}{l}\text { c. } 23^{\circ} 57^{\prime} 55^{\prime} \mathrm{S}, \\
47^{\circ} 30^{\prime} 19^{\prime \prime} \mathrm{W} ; 870 \mathrm{~m} \\
\text { a.s.1. }\end{array}$ & $\begin{array}{l}\text { B. hermogenesi: Verdade et al. } \\
\text { (2008), Condez, Sawaya \& Dixo } \\
\text { (2009); Brachycephalus sp. cf. B. } \\
\text { sulfuratus or B. hermogenesi: } \\
\text { Bornschein, Pie \& Teixeira (2019a) }\end{array}$ & Specimen & --- \\
\hline $\begin{array}{l}\text { Brachycephalus } \\
\text { sp. }\end{array}$ & $\begin{array}{l}\text { Parque Estadual de } \\
\text { Jacupiranga, municipality } \\
\text { of Eldorado, São Paulo }\end{array}$ & $\begin{array}{l}\text { c. } 24^{\circ} 38^{\prime} \mathrm{S}, 48^{\circ} 24^{\prime} \mathrm{W} \text {; } \\
\text { altitude? }\end{array}$ & $\begin{array}{l}\text { B. hermogenesi: Condez et al. } \\
\text { (2016); Brachycephalus sp. cf. B. } \\
\text { sulfuratus or B. hermogenesi: } \\
\text { Bornschein, Pie \& Teixeira (2019a) }\end{array}$ & Specimen & --- \\
\hline
\end{tabular}




\begin{tabular}{|c|c|c|c|c|c|}
\hline Species & Locality and state & $\begin{array}{l}\text { Geographical } \\
\text { coordinates and altitude }\end{array}$ & Previous identification & Voucher & Our analysis of the record \\
\hline $\begin{array}{l}\text { Brachycephalus } \\
\text { sp. }\end{array}$ & $\begin{array}{l}\text { Pico Agudinho, Serra da } \\
\text { Prata, municipality of } \\
\text { Morretes, Paraná }\end{array}$ & $\begin{array}{l}25^{\circ} 36^{\prime} 24^{\prime \prime}, \\
48^{\circ} 43^{\prime} 33^{\prime \prime}, 385 \mathrm{~m} \\
\text { a.s.1. }\end{array}$ & $\begin{array}{l}\text { Brachycephalus sp. nov. 1: Pie et al. } \\
\text { (2013); Brachycephalus sp. 1: } \\
\text { Bornschein et al. (2016a); } \\
\text { Brachycephalus sp. cf. B. sulfuratus: } \\
\text { Bornschein, Pie \& Teixeira (2019a) }\end{array}$ & Unvouchered & $\begin{array}{l}\text { The calls resemble those of } \\
\text { B. sulfuratus (auditory record } \\
\text { made by MRB). }\end{array}$ \\
\hline $\begin{array}{l}\text { Brachycephalus } \\
\text { sp. }\end{array}$ & $\begin{array}{l}\text { Reserva Betary, } \\
\text { municipality of Iporanga, } \\
\text { São Paulo }\end{array}$ & $\begin{array}{l}24^{\circ} 33^{\prime} 08^{\prime \prime} \mathrm{S}, \\
48^{\circ} 40^{\prime} 49^{\prime \prime} \mathrm{W} ; 190 \mathrm{~m} \\
\text { a.s.1. }\end{array}$ & $\begin{array}{l}\text { Brachycephalus sp. cf. B. sulfuratus } \\
\text { or B. hermogenesi: Bornschein, Pie } \\
\& \text { Teixeira (2019a) }\end{array}$ & Specimen & $\begin{array}{l}\text { Specimen examined (ZUEC } \\
\text { 19931). }\end{array}$ \\
\hline $\begin{array}{l}\text { Brachycephalus } \\
\text { sp. }\end{array}$ & $\begin{array}{l}\text { Reserva Biológica do Alto } \\
\text { da Serra de Paranapiacaba, } \\
\text { municipality of Santo } \\
\text { André, São Paulo }\end{array}$ & $\begin{array}{l}23^{\circ} 46^{\prime} 40^{\prime \prime} \mathrm{S}, \\
46^{\circ} 18^{\prime} 45^{\prime}{ }^{\prime} \mathrm{W} ; 800-850 \\
\text { m a.s.l. }\end{array}$ & $\begin{array}{l}\text { B. hermogenesi: Verdade et al. } \\
\text { (2008), Verdade, Rodrigues \& } \\
\text { Pavan (2009); Brachycephalus sp. } \\
\text { cf. B. sulfuratus or B. hermogenesi: } \\
\text { Bornschein, Pie \& Teixeira (2019a) }\end{array}$ & Unvouchered & --- \\
\hline $\begin{array}{l}\text { Brachycephalus } \\
\text { sp. }\end{array}$ & $\begin{array}{l}\text { Reserva Florestal de Morro } \\
\text { Grande, municipality of } \\
\text { Cotia, São Paulo }\end{array}$ & $\begin{array}{l}23^{\circ} 42^{\prime} 08^{\prime \prime} \mathrm{S}, \\
46^{\circ} 58^{\prime} 22 ’ \mathrm{~W} \text {; cf. } 990 \mathrm{~m} \\
\text { a.s.1. }\end{array}$ & $\begin{array}{l}\text { B. hermogenesi: Dixo and Verdade } \\
\text { (2006), Verdade et al. (2008), } \\
\text { Condez et al. (2016); } \\
\text { Brachycephalus sp. cf. B. sulfuratus } \\
\text { or B. hermogenesi: Bornschein, Pie } \\
\text { \& Teixeira (2019a) }\end{array}$ & Specimen & --- \\
\hline $\begin{array}{l}\text { Brachycephalus } \\
\text { sp. }\end{array}$ & $\begin{array}{l}\text { Sítio Ananias, municipality } \\
\text { of Guaratuba, Paraná }\end{array}$ & $\begin{array}{l}25^{\circ} 47^{\prime} 08^{\prime \prime} \mathrm{S}, \\
48^{\circ} 43^{\prime} 03^{\prime \prime} \mathrm{W} ; 25 \mathrm{~m} \\
\text { a.s.1. }\end{array}$ & $\begin{array}{l}\text { Brachycephalus sp. nov. 1: Pie et al. } \\
\text { (2013); Brachycephalus sp. 1: } \\
\text { Bornschein et al. (2016a); }\end{array}$ & Unvouchered & $\begin{array}{l}\text { The calls resemble those of } \\
\text { B. sulfuratus (auditory record } \\
\text { made by MRB). }\end{array}$ \\
\hline
\end{tabular}




\begin{tabular}{|c|c|c|c|c|c|}
\hline Species & Locality and state & $\begin{array}{l}\text { Geographical } \\
\text { coordinates and altitude }\end{array}$ & Previous identification & Voucher & Our analysis of the record \\
\hline & & & $\begin{array}{l}\text { Brachycephalus sp. cf. B. sulfuratus: } \\
\text { Bornschein, Pie \& Teixeira (2019a) }\end{array}$ & & \\
\hline \multicolumn{6}{|c|}{ Brachycephalus sp. (B. hermogenesi or Brachycephalus sp. from Corcovado and Trilha do Corisco) } \\
\hline $\begin{array}{l}\text { Brachycephalus } \\
\text { sp. }\end{array}$ & $\begin{array}{l}\text { Morro Cuscuzeiro, on the } \\
\text { border of municipalities of } \\
\text { Paraty, Rio de Janeiro, and } \\
\text { Ubatuba, São Paulo }\end{array}$ & $\begin{array}{l}23^{\circ} 17^{\prime} 50 ” S, \\
44^{\circ} 47^{\prime} 21 ’ \mathrm{~W} ; 730- \\
1,090 \text { a.s.1. }\end{array}$ & $\begin{array}{l}\text { B. hermogenesi: Bornschein, Pie \& } \\
\text { Teixeira (2019a) }\end{array}$ & Unvouchered & $\begin{array}{l}\text { The calls resemble those of } \\
\text { Brachycephalus sp. of Trilha } \\
\text { do Corisco (auditory record } \\
\text { made by MRB and LFR). }\end{array}$ \\
\hline $\begin{array}{l}\text { Brachycephalus } \\
\text { sp. }\end{array}$ & $\begin{array}{l}\text { Morro do Corcovado, } \\
\text { Parque Estadual da Serra do } \\
\text { Mar, municipality of } \\
\text { Ubatuba, São Paulo }\end{array}$ & $\begin{array}{l}23^{\circ} 27^{\prime} 06^{\prime \prime} \mathrm{S}, \\
45^{\circ} 12^{\prime} 03^{\prime \prime} \mathrm{W} ; 250- \\
1,060 \mathrm{~m} \text { a.s.l. }\end{array}$ & $\begin{array}{l}\text { B. hermogenesi: Bornschein, Pie \& } \\
\text { Teixeira (2019a) }\end{array}$ & Unvouchered & $\begin{array}{l}\text { The calls resemble those of } \\
\text { Brachycephalus sp. of Trilha } \\
\text { do Corisco (auditory record } \\
\text { made by MRB and LFR). }\end{array}$ \\
\hline $\begin{array}{l}\text { Brachycephalus } \\
\text { sp. }\end{array}$ & $\begin{array}{l}\text { Municipality of Paraty, Rio } \\
\text { de Janeiro }\end{array}$ & $\begin{array}{l}\text { c. } 23^{\circ} 13^{\prime} 07^{\prime} \mathrm{S} \text {, } \\
44^{\circ} 43^{\prime} 15^{\prime \prime} \mathrm{W} \text {; altitude? }\end{array}$ & $\begin{array}{l}\text { B. hermogenesi: Giaretta and } \\
\text { Sawaya (1998); Brachycephalus sp. } \\
\text { cf. B. hermogenesi: Bornschein, Pie } \\
\text { \& Teixeira (2019a) }\end{array}$ & Unvouchered & --- \\
\hline
\end{tabular}




\section{Table 2 (on next page)}

Structure of the advertisements calls recording between the geographical distribution of flea toads at some point identified as $B$. sulfuratus, $B$. hermogenesi, and as an unidentified related species

Table 2. Structure of the advertisements calls $(A C)$ recording by the author between the geographical distribution of flea toads at some point identified as Brachycephalus sulfuratus, B. hermogenesi, and as an unidentified related species, southeastern and southern Brazil. Each number represents a note, while the numerical value indicates the number of pulses for each note. Numbers in normal font outside parentheses represent isolated notes and those in normal font between parentheses represents note groups. Numbers in subscript represents attenuated notes (see text for reasons why we do not consider it as forming note groups). Question marks ("?") represents a note issued whose number of pulses could not be counted. Abbreviations: $A=$ number of isolated notes we hear being emitted before recording the $A C$; $B=A C$ emission probably interrupted due to the researcher movement in the field. 
Table 2. Structure of the advertisements calls (AC) recording by the author between the geographical distribution of flea toads at some point identified as Brachycephalus sulfuratus, B. hermogenesi, and as an unidentified related species, southeastern and southern Brazil. Each number represents a note, while the numerical value indicates the number of pulses for each note. Numbers in normal font outside parentheses represent isolated notes and those in normal font between parentheses represents note groups. Numbers in subscript represents attenuated notes (see text for reasons why we do not consider it as forming note groups). Question marks (“'”) represents a note issued whose number of pulses could not be counted. Abbreviations: A = number of isolated notes we hear being emitted before

recording the $\mathrm{AC} ; \mathrm{B}=\mathrm{AC}$ emission probably interrupted due to the researcher movement in the field.

\begin{tabular}{|c|c|c|c|}
\hline $\begin{array}{l}\text { Individuals (Ind) and call } \\
\text { deposit number }\end{array}$ & Call structure & A & $\mathrm{B}$ \\
\hline \multicolumn{4}{|l|}{ B. sulfuratus } \\
\hline Ind 01 (MHNCI 123), ex 01 & $14,11,11,11,10,9,8$ & 0 & \\
\hline Ind 01 (MHNCI 123), ex 02 & $12,10,11,10,10,9,8$ & 0 & \\
\hline Ind 01 (MHNCI 123), ex 03 & $12,11,10,9,10,9,8$ & 0 & \\
\hline Ind 01 (MHNCI 123), ex 04 & $14,11,10,10,10,10,8$ & 0 & \\
\hline Ind 02 (MHNCI 124), ex 01 & $10,7,6$ & 0 & \\
\hline Ind 02 (MHNCI 124), ex 02 & $6,6,6,6$ & 0 & \\
\hline Ind 02 (MHNCI 124), ex 03 & $9,7,7,7$ & 0 & \\
\hline Ind 02 (MHNCI 124), ex 04 & $10,7,8,7,3$ & 0 & \\
\hline Ind 02 (MHNCI 124), ex 05 & $6,6,7,9,7,4$ & 0 & \\
\hline Ind 02 (MHNCI 124), ex 06 & $10,9,8,8,8,7$ & 0 & \\
\hline Ind 02 (MHNCI 124), ex 07 & $10,9,8,9,9,8,7$ & 0 & \\
\hline Ind 02 (MHNCI 124), ex 08 & $10,7,10,8,9,8$ & 0 & \\
\hline
\end{tabular}




\begin{tabular}{lll}
\hline $\begin{array}{l}\text { Individuals (Ind) and call } \\
\text { deposit number }\end{array}$ & Call structure & $\mathrm{A}$ \\
\hline Ind 02 (MHNCI 124), ex 09 & $9,7,8,8,8,7$ & 0 \\
Ind 02 (MHNCI 124), ex 10 & $10,8,7,7,8$ & 0 \\
Ind 03 (MHNCI 125), ex 01 & $12,10,9,9,9,8$ & 0 \\
Ind 03 (MHNCI 125), ex 02 & $13,9,10,10,9,8$ & 0 \\
Ind 03 (MHNCI 125), ex 03 & $10,9,9,9,9,9$ & 0 \\
Ind 03 (MHNCI 125), ex 04 & $13,9,10,9,10,8$ & 0 \\
Ind 03 (MHNCI 125), ex 05 & $13,10,10,10,9,9$ & 0 \\
Ind 03 (MHNCI 125), ex 06 & $11,9,10,10,9,8$ & 0 \\
Ind 03 (MHNCI 125), ex 07 & $11,9,9,9,8$ & 0 \\
Ind 03 (MHNCI 125), ex 08 & $12,9,9,9,9,8$ & 0 \\
Ind 04 (MHNCI 126), ex 01 & $?, ?, 9,8,8$ & 0 \\
Ind 04 (MHNCI 126), ex 02 & $7,8,8,8,7$ & 0 \\
Ind 04 (MHNCI 126), ex 03 & $6,8,7,7,7$ & 0 \\
Ind 04 (MHNCI 126), ex 04 & $6,8,8,8,8$ & 0 \\
Ind 04 (MHNCI 126), ex 05 & $6,7,7,7,7$ & 0 \\
Ind 04 (MHNCI 126), ex 06 & $5,7,7,8,7,6$ & 0 \\
Ind 05 (MHNCI 127), ex 01 & $?, ?, ?, ?$ & \\
Ind 05 (MHNCI 127), ex 02 & $?, ?, ?, ?$ & 0 \\
Ind 05 (MHNCI 127), ex 03 & $5,6,6,6,5$ & 0 \\
Ind 05 (MHNCI 127), ex 04 & $?, ?, ?, ?, ?$ & 0 \\
\hline
\end{tabular}




\begin{tabular}{lll}
\hline $\begin{array}{l}\text { Individuals (Ind) and call } \\
\text { deposit number }\end{array}$ & Call structure & $\mathrm{A}$ \\
\hline Ind 05 (MHNCI 127), ex 05 & $?, ?, ?, ?, ?, ?$ & 0 \\
Ind 05 (MHNCI 127), ex 06 & $?, ?, ?, ?, ?$ & 0 \\
Ind 05 (MHNCI 127), ex 07 & $7,8,8,8,7$ & 0 \\
Ind 06 (MHNCI 128), ex 01 & $11,10,10,9,8$ & 0 \\
Ind 06 (MHNCI 128), ex 02 & $11,10,10,9,8$ & 0 \\
Ind 06 (MHNCI 128), ex 03 & $11,10,9,10,8$ & 0 \\
Ind 06 (MHNCI 128), ex 04 & $12,10,9,9,8$ & 0 \\
Ind 06 (MHNCI 128), ex 05 & $11, ?, ?, ?$ & 0 \\
Ind 06 (MHNCI 128), ex 06 & $11,10,9,8,7$ & 0 \\
Ind 06 (MHNCI 128), ex 07 & $11,10,9,9,9$ & 0 \\
Ind 07 (MHNCI 129), ex 01 & 10,8 & 0 \\
Ind 07 (MHNCI 129), ex 02 & 12,8 & 0 \\
Ind 07 (MHNCI 129), ex 03 & 10,8 & 0 \\
Ind 07 (MHNCI 129), ex 04 & $10,8,8$ & 0 \\
Ind 07 (MHNCI 129), ex 05 & $10,8,7$ & 0 \\
Ind 08 (MHNCI 129), ex 01 & $6,5,4,4$ & 0 \\
Ind 08 (MHNCI 129), ex 02 & $9,9,9,9$ & 0 \\
Ind 08 (MHNCI 129), ex 03 & $11,8,9,9,9,9,9$ & 0 \\
Ind 08 (MHNCI 129), ex 04 & $9,9,7,7,9,9$ & 0 \\
Ind 09 (MHNCI 129) & $10,9,9,9, ?, 9,8$ & 0 \\
\hline
\end{tabular}




\begin{tabular}{|c|c|c|c|}
\hline $\begin{array}{l}\text { Individuals (Ind) and call } \\
\text { deposit number }\end{array}$ & Call structure & A & B \\
\hline Ind 10 (MHNCI 130), ex 01 & $10,7,7,6$ & 0 & \\
\hline Ind 10 (MHNCI 130), ex 02 & $8,9,7$ & 0 & \\
\hline Ind 11 (MHNCI 130), ex 01 & $?, ?, ?, ?, ?, ?$ & 0 & \\
\hline Ind 11 (MHNCI 130), ex 02 & $?, ?, ?, ?, ?, ?, ?$ & 0 & \\
\hline Ind 11 (MHNCI 130), ex 03 & $?, ?, ?, ?, ?, ?$ & 0 & \\
\hline Ind 11 (MHNCI 130), ex 04 & $?, ?, ?, ?, ?$ & 0 & \\
\hline Ind 11 (MHNCI 130), ex 05 & $11,10,9,9,9,9,8$ & 0 & \\
\hline Ind 11 (MHNCI 130), ex 06 & $12,9,9,9,9,9,8$ & 0 & \\
\hline Ind 11 (MHNCI 130), ex 07 & $11,10,9,9,9,8$ & 0 & \\
\hline Ind 11 (MHNCI 130), ex 08 & $11,9,8,9,8,8$ & 0 & \\
\hline Ind 11 (MHNCI 130), ex 09 & $?, ?, 9,9, ?, 8$ & 0 & \\
\hline Ind 11 (MHNCI 130), ex 10 & $?, 9,8, ?, 8,8$ & 0 & \\
\hline Ind 12 (MHNCI 131), ex 01 & $7,6,6,5,5,4$ & 0 & \\
\hline Ind 12 (MHNCI 131), ex 02 & $7,6,5,6,7,5$ & 0 & \\
\hline Ind 12 (MHNCI 131), ex 03 & $8,6,6,6,6,5$ & 0 & \\
\hline Ind 13 (MHNCI 132), ex 01 & $10,7,7,7$ & 0 & \\
\hline Ind 13 (MHNCI 132), ex 02 & $9,8,8,8,8$ & 0 & \\
\hline Ind 13 (MHNCI 132), ex 03 & $10,8,8,8,8$ & 0 & \\
\hline Ind 13 (MHNCI 132), ex 04 & $10,9,9,9,8$ & 0 & \\
\hline Ind 13 (MHNCI 132), ex 05 & $10,9,9,9,9$ & 0 & \\
\hline
\end{tabular}




\begin{tabular}{|c|c|c|c|}
\hline $\begin{array}{l}\text { Individuals (Ind) and call } \\
\text { deposit number }\end{array}$ & Call structure & A & B \\
\hline Ind 13 (MHNCI 132), ex 06 & $10,9,9,9,8$ & 0 & \\
\hline Ind 13 (MHNCI 132), ex 07 & $10,9,9,9,9$ & 0 & \\
\hline Ind 13 (MHNCI 132), ex 08 & $11,9,9,9,9$ & 0 & \\
\hline Ind 13 (MHNCI 132), ex 09 & $10,9,8,9,9$ & 0 & \\
\hline Ind 13 (MHNCI 132), ex 10 & $11,9,8,9,8$ & 0 & \\
\hline Ind 13 (MHNCI 132), ex 11 & $10,9,10,8$ & 0 & \\
\hline Ind 13 (MHNCI 132), ex 12 & $10,8,8,8$ & 0 & \\
\hline Ind 14 (MHNCI 133), ex 01 & $?, ?, ?, ?$ & 0 & \\
\hline Ind 14 (MHNCI 133), ex 02 & $?, ?, ?, ?$ & 0 & \\
\hline Ind 14 (MHNCI 133), ex 03 & $?, ?, ?, ?, ?, ?$ & 0 & \\
\hline Ind 14 (MHNCI 133), ex 04 & $?, ?, ?, ?, ?, ?$ & 0 & \\
\hline Ind 14 (MHNCI 133), ex 05 & $?, ?, ?, ?, ?, ?$ & 0 & \\
\hline Ind 14 (MHNCI 133), ex 06 & $11,10,9,11,9$ & 0 & \\
\hline Ind 14 (MHNCI 133), ex 07 & $?, ?, 10,9,8$ & 0 & \\
\hline Ind 14 (MHNCI 133), ex 08 & $8,9,9,9, ?$ & 0 & \\
\hline Ind 14 (MHNCI 133), ex 09 & $?, ?, ?, ?$ & 0 & \\
\hline Ind 15 (MHNCI 134) & $9,7,7,7,6,6$ & 0 & \\
\hline Ind 16 (MHNCI 135), ex 01 & $5,5,5,5$ & 0 & \\
\hline Ind 16 (MHNCI 135), ex 02 & $?, ?, ?, ?, ?$ & 0 & \\
\hline Ind 17 (MHNCI 136), ex 01 & $11,8,7,8,7$ & 0 & \\
\hline
\end{tabular}




\begin{tabular}{|c|c|c|}
\hline $\begin{array}{l}\text { Individuals (Ind) and call } \\
\text { deposit number }\end{array}$ & Call structure & A \\
\hline Ind 17 (MHNCI 136), ex 02 & $12,9,8,8,8$ & 0 \\
\hline Ind 17 (MHNCI 136), ex 03 & $12,9,8,8,8$ & 0 \\
\hline Ind 17 (MHNCI 136), ex 04 & $12,9,8,7$ & 0 \\
\hline Ind 17 (MHNCI 136), ex 04 & $10,9,8,5$ & 0 \\
\hline Ind 17 (MHNCI 136), ex 06 & $10,8,5,3$ & 0 \\
\hline Ind 17 (MHNCI 136), ex 07 & $10,8,5$ & 0 \\
\hline Ind 17 (MHNCI 136), ex 08 & $9,8,6$ & 0 \\
\hline Ind 17 (MHNCI 136), ex 09 & $8,8,7$ & 0 \\
\hline Ind 17 (MHNCI 136), ex 10 & $9,8,7,5$ & 0 \\
\hline Ind 18 (MHNCI 137), ex 01 & $6,7,6,2$ & 0 \\
\hline Ind 18 (MHNCI 137), ex 02 & $6,7,6,2$ & 0 \\
\hline Ind 18 (MHNCI 137), ex 03 & $?, 7,7,6$ & 0 \\
\hline Ind 18 (MHNCI 137), ex 04 & $8,7,8,7$ & 0 \\
\hline Ind 19 (MHNCI 217), ex. 01 & $?, ?, 10,10,9$ & 0 \\
\hline Ind 19 (MHNCI 217), ex. 02 & $9,10,10,9,10$ & 0 \\
\hline Ind 20 (MHNCI 218), ex 01 & $?, 10,10, ?, ?, ?$ & 0 \\
\hline Ind 20 (MHNCI 218), ex 02 & $?, ?, ?, ?, ?, ?$ & 0 \\
\hline Ind 21 (MHNCI 219), ex 01 & $9,7,7$ & 0 \\
\hline Ind 21 (MHNCI 219), ex 02 & $9,7,7,6$ & 0 \\
\hline Ind 21 (MHNCI 219), ex 03 & $9,7,7,7$ & 0 \\
\hline
\end{tabular}




\begin{tabular}{|c|c|c|}
\hline $\begin{array}{l}\text { Individuals (Ind) and call } \\
\text { deposit number }\end{array}$ & Call structure & A \\
\hline Ind 21 (MHNCI 219), ex 04 & $9,9,8,8,8$ & 0 \\
\hline Ind 21 (MHNCI 219), ex 05 & $10,8,8,8,8,8,8$ & 0 \\
\hline Ind 21 (MHNCI 219), ex 06 & $10,9,9,8,8,8$ & 0 \\
\hline Ind 21 (MHNCI 219), ex 07 & $10,9,9,8,8,8$ & 0 \\
\hline Ind 21 (MHNCI 219), ex 08 & $10,9,9,9,8$ & 0 \\
\hline Ind 21 (MHNCI 219), ex 09 & $10,9,9,9,9,9,9,8$ & 0 \\
\hline Ind 21 (MHNCI 219), ex 10 & $9,9,8,8$ & 0 \\
\hline Ind 21 (MHNCI 219), ex 11 & $10,8,7$ & 0 \\
\hline Ind 21 (MHNCI 219), ex 12 & $10,8,6$ & 0 \\
\hline Ind 21 (MHNCI 219), ex 13 & $9,7,6$ & 0 \\
\hline Ind 21 (MHNCI 219), ex 14 & $9,8,7$ & 0 \\
\hline Ind 21 (MHNCI 219), ex 15 & $10,8,7$ & 0 \\
\hline Ind 21 (MHNCI 219), ex 16 & $10,8,7$ & 0 \\
\hline Ind 21 (MHNCI 219), ex 17 & $10,8,7$ & 0 \\
\hline Ind 21 (MHNCI 219), ex 18 & $10,8,7$ & 0 \\
\hline Ind 21 (MHNCI 219), ex 19 & $10,9,8$ & 0 \\
\hline Ind 21 (MHNCI 219), ex 20 & $10,9,8$ & 0 \\
\hline Ind 21 (MHNCI 219), ex 21 & $10,9,8,8$ & 0 \\
\hline Ind 21 (MHNCI 219), ex 22 & $10,9,9,8$ & 0 \\
\hline Ind 21 (MHNCI 219), ex 23 & $10,9,8$ & 0 \\
\hline
\end{tabular}




\begin{tabular}{lll}
\hline $\begin{array}{l}\text { Individuals (Ind) and call } \\
\text { deposit number }\end{array}$ & Call structure & $\mathrm{A}$ \\
\hline Ind 21 (MHNCI 219), ex 24 & $10,9,8$ & 0 \\
Ind 21 (MHNCI 219), ex 25 & $10,9,8$ & 0 \\
Ind 22 (MHNCI 220), ex 01 & $11,8,7,7,7,7$ & 0 \\
Ind 22 (MHNCI 220), ex 02 & $10,8,7,7,8,8$ & 0 \\
Ind 22 (MHNCI 220), ex 03 & $9,8,7,7,8,7$ & 0 \\
Ind 22 (MHNCI 220), ex 04 & $9,8,7,8,7,7$ & 0 \\
Ind 22 (MHNCI 220), ex 05 & $10,8,8,8,8,8$ & 0 \\
Ind 22 (MHNCI 220), ex 06 & $9,8,8,8,8,8$ & 0 \\
Ind 22 (MHNCI 220), ex 07 & $10,8,8,8,8,8$ & 0 \\
Ind 22 (MHNCI 220), ex 08 & $10,8,8,8,8,8$ & 0 \\
Ind 22 (MHNCI 220), ex 09 & $10,8,8,8,8$ & 0 \\
Ind 22 (MHNCI 220), ex 10 & $10,8,9,8,8,8$ & 0 \\
Ind 22 (MHNCI 220), ex 11 & $10,8,7,8,8,7$ & 0 \\
Ind 22 (MHNCI 220), ex 12 & $10,8,8,8,8,8$ & 0 \\
Ind 22 (MHNCI 220), ex 13 & $10,8,8,8,7,7$ & 0 \\
Ind 22 (MHNCI 220), ex 14 & $10,8,8,8,8,6$ & 0 \\
Ind 22 (MHNCI 220), ex 15 & $10,8,8,8,8,7$ & 0 \\
Ind 22 (MHNCI 220), ex 16 & $9,8,7,8,7$ & 0 \\
Ind 22 (MHNCI 220), ex 17 & $10,9,7,8,7$ & 0 \\
Ind 23 (MHNCI 221), ex 01 & $8,7,6,7,6,5$ & 0
\end{tabular}




\begin{tabular}{|c|c|c|}
\hline $\begin{array}{l}\text { Individuals (Ind) and call } \\
\text { deposit number }\end{array}$ & Call structure & A \\
\hline Ind 23 (MHNCI 221), ex 02 & $8,7,7,7,7,4$ & 0 \\
\hline Ind 23 (MHNCI 221), ex 03 & $8,7,7,7,6$ & 0 \\
\hline Ind 23 (MHNCI 221), ex 04 & $8,6,7,7,6$ & 0 \\
\hline Ind 23 (MHNCI 221), ex 05 & $8,7,7,7,6$ & 0 \\
\hline Ind 23 (MHNCI 221), ex 06 & $8,7,8,7,7$ & 0 \\
\hline Ind 23 (MHNCI 221), ex 07 & $8,8,7,7,7$ & 0 \\
\hline Ind 23 (MHNCI 221), ex 08 & $8,8,8,7,7$ & 0 \\
\hline Ind 23 (MHNCI 221), ex 09 & $9,8,7,8,7$ & 0 \\
\hline Ind 23 (MHNCI 221), ex 10 & $9,8,8,8,7$ & 0 \\
\hline Ind 23 (MHNCI 221), ex 11 & $9,8,7,7$ & 0 \\
\hline Ind 23 (MHNCI 221), ex 12 & $8,7,6$ & 0 \\
\hline Ind 23 (MHNCI 221), ex 13 & $9,7,7,6$ & 0 \\
\hline Ind 23 (MHNCI 221), ex 14 & $8,7,7,7,7$ & 0 \\
\hline Ind 23 (MHNCI 221), ex 15 & $9,7,7,7,7$ & 0 \\
\hline Ind 23 (MHNCI 221), ex 16 & $8,7,8,7,6$ & 0 \\
\hline Ind 23 (MHNCI 221), ex 17 & $8,8,8,7,7$ & 0 \\
\hline Ind 23 (MHNCI 221), ex 18 & $9,8,7,8$ & 0 \\
\hline Ind 23 (MHNCI 221), ex 19 & $9,8,8,7,7$ & 0 \\
\hline Ind 23 (MHNCI 221), ex 20 & $9,8,7,7,7$ & 0 \\
\hline Ind 23 (MHNCI 221), ex 21 & $8,7,7,7,7$ & 0 \\
\hline
\end{tabular}




\begin{tabular}{|c|c|c|c|}
\hline $\begin{array}{l}\text { Individuals (Ind) and call } \\
\text { deposit number }\end{array}$ & Call structure & A & B \\
\hline Ind 23 (MHNCI 221), ex 22 & $9,8,7,7$ & 0 & \\
\hline Ind 23 (MHNCI 221), ex 23 & $9,7,7,6$ & 0 & \\
\hline Ind 23 (MHNCI 221), ex 24 & $9,7,7,7$ & 0 & \\
\hline \multicolumn{4}{|l|}{ B. hermogenesi (Corcovado) } \\
\hline Ind 01 (MHNCI 165) & $\begin{array}{l}2,2,2,2,2,2,2,2,2,2,2,2,2,2,2,2,2,2,2,2,2,2,2,2,2,2,2,2,2,(2-2),(2-2),(2-2),(2- \\
2),(2-2-2),(2-2-2),(2-2-2),(2-2-2-2),(2-2-2),(2-2-2-2),(2-2-2),(2-2-2-2),(2-2-2-2),(2-2-2- \\
2),(2-2-2-2),(2-2-2),(2-2-2),(2-2-2-2),(2-2-2),(2-2-2-2),(2-2-2-2),(2-2-2-2),(2-2-2),(2-2- \\
2-2),(2-2-2),(2-2-2-2),(2-2-2-2),(2-2-2),(2-2-2-2),(2-2-2),(2-2-2),(2-2-2)\end{array}$ & 2 & \\
\hline \multicolumn{4}{|c|}{ B. hermogenesi (Estação Biológica de Boracéia) } \\
\hline Ind 01 (MHNCI 166) & $\begin{array}{l}2,2,2,2,2,2,2,2,2,2,2,2,2,2,2,(2-2), 2,2,2,(2-2),(2-2),(2-2),(2-2),(2-2),(2-2),(2-2), \\
(2-2),(2-2-2),(2-2-2),(2-2-2),(2-2-2),(2-2-2-1),(2-2-2-2),(2-2-2),(2-2-2),(2-2-2-2),(2-2-2- \\
2),(2-2-2-2),(2-2-1-1),(2-2-2-2),(2-2-2-2),(2-2-2-2),(3-2-2-2),(2-2-2-2),(2-2-2),(2-2-2-2), \\
(3-2-2-2),(2-2-2),(2-2-2),(2-2-2),(2-2-2),(3-2-2),(2-2-2)\end{array}$ & 6 & \\
\hline Ind $02(\mathrm{MHNCI} 167)$ & $\begin{array}{l}2,1,2,2,1,2,2,2,2,1,2,2,2,2,2,2,2,2,2,2,2,2,2,2,(2-2),(2-2),(2-2),(2-2),(2-2),(2- \\
2-2),(2-2-2),(2-2-2),(2-2-2),(2-2-1),(2-2-2),(2-2-1),(2-1-2-2),(2-2-1),(2-2-1-1),(2-2-2), \\
(2-2-2),(2-2-2),(2-2-1-1),\left(2-1-1-{ }_{-1}\right),\left(2-1-{ }_{1-1}\right),\left(2-1-_{-1-1-1-1),(2-2-1)}\right.\end{array}$ & 7 & \\
\hline Ind 03 (MHNCI 168) & $\begin{array}{l}2,2,2,2,2,2,2,2,2,2,2,2,2,2,2,2,2,2,2,2,(2-2),(2-2),(2-2),(2-2-2),(2-2-2),(2-2-2), \\
(2-2-2),(2-2-2-2),(2-2-2-2-2),(2-2-2-2),(2-2-2),(2-2-2-2),(2-2-2-2),(2-2-2),(2-2-2-2),(2-2- \\
2-2)\end{array}$ & 3 & \\
\hline Ind 04 (MHNCI 169) & $1,1,1,1,1,1,1,1,1,1,1,2,2, ?, ?, 2,2,2,2,(2-2),(2-2-2),(2-2),(2-2),(2-2),(2-2),(2-2)$ & 3 & \\
\hline
\end{tabular}




\begin{tabular}{|c|c|c|c|}
\hline $\begin{array}{l}\text { Individuals (Ind) and call } \\
\text { deposit number }\end{array}$ & Call structure & $\mathrm{A}$ & B \\
\hline & $\begin{array}{l}(2-?-?),(2-2-2),(2-2),(2-2-2),(2-2-2),(2-?-2),(2-?-2),(2-2-2-1),(2-2-1),(2-2-2-2),(?-?-?-?) \\
(2-?-?-?),(2-1-1),(2-2-2),(2-2-2),(?-2-?),(2-1-2),(2-1-2)\end{array}$ & & \\
\hline \multicolumn{4}{|c|}{ B. hermogenesi (Morro do Cantagalo) } \\
\hline Ind 01 (MHNCI 222) & $?, ?, ?, ?, 2,2, ?, 2,2,2$ & $?$ & $\mathrm{X}$ \\
\hline Ind 02 (MHNCI 223) & $2,(2-2-2),(2-2-2),(2-2-2),(2-2-2),(2-2-2-2),(2-2-2-2),(2-2-2-2),(2-2-2-2)$ & $?$ & $\mathrm{X}$ \\
\hline \multicolumn{4}{|c|}{ B. hermogenesi (Núcleo Cunha) } \\
\hline Ind 01 (MHNCI 170), ex 01 & $2,2,2,2,2,2,2,2,2,2,2,2,(2-2), 2,2,(2-2),(2-2),(2-2),(2-2)$ & 0 & \\
\hline Ind 01 (MHNCI 171), ex 02 & $\begin{array}{l}1,1,1,1,2,2,2,2,2,2,2,2,2,2, ?, 2,2,2,2,2,2,2,2,2,(2-2), 2,(2-2),(2-?), 2,(2-2),(2- \\
2),(2-2),(2-2)\end{array}$ & 0 & \\
\hline \multicolumn{4}{|c|}{ B. hermogenesi (Núcleo Picinguaba) } \\
\hline Ind 01 (MHNCI 172), ex 01 & $\begin{array}{l}2,2,2,2,2,2,2,2,2,2,2,2,2,2,2,2,2,(2-2),(2-2),(2-2),(2-2),(2-2),(2-2),(2-2),(2-2), \\
(2-2),(2-2-2),(2-2-2),(2-2-2),(2-2-2),(2-2-2),(2-2-2),(2-2-2),(2-2-2),(2-2-1),(2-2),(2-2), \\
(2-2),(2-2)\end{array}$ & $?$ & \\
\hline Ind 01(MHNCI 175), ex 02 & $\begin{array}{l}1,2,1,1,2,2,2,2,2,2,2,2,2,2,2,2,2,2,2,2,2,(2-1),(2-2),(2-2),(2-2),(2-2),(2-2),(2- \\
2),(2-2)\end{array}$ & 0 & \\
\hline Ind 02 (MHNCI 173), ex 01 & $\begin{array}{l}2,2,2,2,2,2,2,(2-1),(2-2),(2-2),(2-2),(2-2),(2-2),(2-2),(2-2-1),(2-1-1),(2-2-2),(2-1-2), \\
(2-2),(2-2-1),(2-2-1),(2-1),(2-1),(1-1),(1-1),(1-1), 1\end{array}$ & 4 & \\
\hline Ind 02 (MHNCI 177), ex 02 & $\begin{array}{l}1,2,2,2,2,2,2,2,2,2,2,2,2,2,(2-2), 2,(2-2),(2-2),(2-1),(2-2),(2-2),(2-2-2),(2-2-2),(2- \\
2-2),(2-2-2),(2-2-1),(2-1),(2-2),(1-1),(1-1)\end{array}$ & 0 & \\
\hline Ind 02 (MHNCI 182), ex 03 & $(2-2),(2-2),(2-2),(2-2),(2-2),(2-2)$ & $?$ & \\
\hline
\end{tabular}




\begin{tabular}{|c|c|c|c|}
\hline $\begin{array}{l}\text { Individuals (Ind) and call } \\
\text { deposit number }\end{array}$ & Call structure & A & B \\
\hline Ind 03 (MHNCI 174), ex 01 & $\begin{array}{l}2,2,2,2,2,2,2,2,2,2,2,2,2,2,2,2,(2-2),(2-2),(2-2),(2-2),(2-2),(2-2),(2-2),(2-2),(2-2- \\
\text { 2), (2-2-2), (2-2-2), (2-2), (2-2-2), (2-2-2), (2-2-2), (2-2-2), (2-2-2), (2-2), (2-2-2), (2-2-1), (2- } \\
\text { 2) }\end{array}$ & 6 & \\
\hline Ind 03 (MHNCI 178), ex 02 & $\begin{array}{l}2,2,2,2,2,2,2,2,2,2,2,2,2,(2-2),(2-2),(2-2),(2-2),(2-2),(2-2),(2-2),(2-2),(2-2),(2-2- \\
2),(2-2-2),(2-2-2),(2-2-2),(2-2-2),(2-2-2),(2-2),(2-2-2)\end{array}$ & 5 & \\
\hline Ind 03 (MHNCI 180), ex 03 & $\begin{array}{l}2,2,2,2,2,2,2,2,(2-2),(2-2),(2-2),(2-2),(2-2),(2-2-2),(2-2),(2-2-2),(2-2-2),(2-2-2),(2- \\
2-2),(2-2-2),(2-2-2),(2-2-2),(2-2-2),(2-2-2),(2-2-1),(2-2-2),(2-2-1),(2-2-1),(2-2-1),(2-2- \\
\text { 1) }\end{array}$ & $?$ & \\
\hline Ind 03 (MHNCI 181), ex 04 & $\begin{array}{l}?, 2,2,2,2,2,2,2,2,2,2,2,2,2,2,2,2,2,2,(2-2),(2-2),(2-2),(2-2),(2-2),(2-2),(2-2),(2- \\
2),(2-2),(2-2),(2-2-2),(2-2),(2-2),(2-2-2),(2-2-2),(2-2-2),(2-2-2),(2-2-2),(2-2-1)\end{array}$ & 1 & \\
\hline Ind 04 (MHNCI 176), ex 01 & $\begin{array}{l}2,2,2,2,2,2,2,2,2,2,2,(2-2-1),(2-2-2),(2-2-1),(2-2-2),(2-2-1),(2-2-2),(2-2-1),(2-2-1), \\
(2-2-1),(2-2-1),(2-2-1),(2-2),(2-2-1),(2-2-1),(2-2-1),(2-2),(2-2),(2-2)\end{array}$ & 3 & \\
\hline Ind 04 (MHNCI 179), ex 02 & $(2-2),(2-2-2),(2-2-1),(2-2-1),(2-2-1),(2-2-2),(2-2-1),(2-2),(2-1)$ & $?$ & \\
\hline Ind 04 (MHNCI 183), ex 03 & 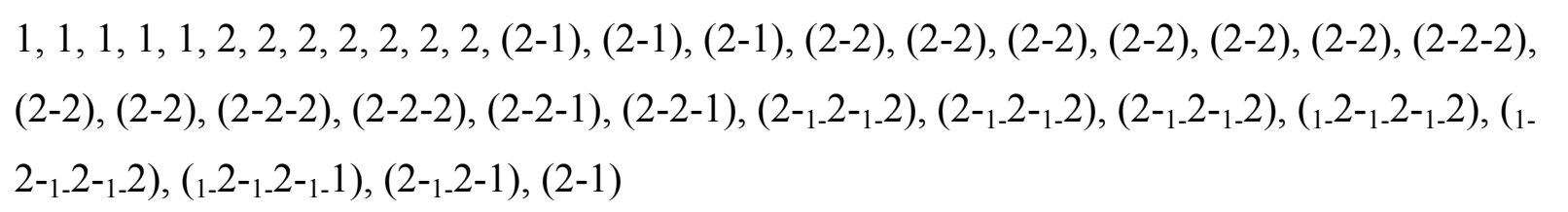 & 0 & \\
\hline Ind 05 (MHNCI 184) & $(2-2-2),(2-2-2),(2-2-2),(2-2-2),(2-2-2),(2-2-2),(2-2-1),(2-2-2),(2-2-1)$ & $?$ & \\
\hline Ind 06 (MHNCI 185) & $\begin{array}{l}1,1,2,2,1,1,2,2,2,2,2,(2-1),(2-1), 2,(2-1), 2,(2-2),(2-2),(2-2),(2-2),(2-2),(2-1),(2-1) \\
(2-1),(2-2),(2-2),(2-2)\end{array}$ & 2 & \\
\hline Ind 07 (MHNCI 186) & $1,2,2,2,2,2,2,2,2,2,1,2,2,2,2,1,2,2,2,2,2,(2-2),(2-2),(2-2),(2-2),(2-2),(2-2),(2-$ & 1 & \\
\hline
\end{tabular}




\begin{tabular}{|c|c|c|c|}
\hline $\begin{array}{l}\text { Individuals (Ind) and call } \\
\text { deposit number }\end{array}$ & Call structure & A & $\mathrm{B}$ \\
\hline Ind 08 (MHNCI 187) & $\begin{array}{l}2),(2-2),(2-2),(2-2),(2-2),(2-2),(2-2), 2,2 \\
(2-2-1),(2-2),(2-2),(2-2),(?-?-?),(2-2),(2-2),(2-2),(2-1),(2-2)\end{array}$ & $?$ & \\
\hline \multicolumn{4}{|c|}{ B. hermogenesi (Parque Natural Municipal Nascentes de Paranapiacaba) } \\
\hline Ind 01 (MHNCI 213) & $\begin{array}{l}(?-?-?),(?-?-?),(2-2-2),(2-2-2),(2-2-2),(2-2-2),(2-2-2),(2-2-2),(?-?-?),(?-?-?-?),(?-?-?-?), \\
(?-?-?-?),(?-?-?-?),(1-1-1-1)\end{array}$ & $?$ & \\
\hline Ind 02 (MHNCI 214) & $\begin{array}{l}1,1,1,1,1,1,1,1,1,(1-1), 1,1,1,1,1,1,1,1,1,1,1,1,1,1,1,1,1,1,1,2,1,1,1,2,2,2, \\
1,2,2,2,2,1,2,2,2,1,1,1,1,1,1,1,2,1,1,2,1,2,2,2,2,2,2,2,2,2,2,2,2,2,2,2,2,2, \\
2,2,2,2,2,2,2,2,2,2,(2-2), 2,2,2,2,(2-2), 2,2\end{array}$ & 0 & \\
\hline Ind 03 (MHNCI 215) & $\begin{array}{l}1,1,1,1,1,1,1,1,1,1,1,1,2,2,1,3,2,2,2,3,2,2,2,2,1,2,1,1,2,2,2,2,2,2,1-2,(2-2), \\
(2-2),(2-2),(2-2),(2-2),(1-2-2),(2-2-2),(2-2-2),(1-2-2),(2-2-2),(2-2-2),(1-1-2),(2-2-2),(2- \\
2-2),(2-2-2),(2-2-1-1),(2-1-1-1),(2-1-1-2),(2-2-1-1),(2-2-1-2),(2-2-1),(1-2-1-2),(2-2-2-1)\end{array}$ & 0 & \\
\hline Ind 04 (MHNCI 216) & $\begin{array}{l}1,1,1,1,1,1,1,1,1,1,1,1,1,1,1,1,1,1,1,1,1,1,1,1,2,1,1,1,1,1,1,1,2,1,2,1,1,2, \\
2,2,1,2,2,1,2,2,2,2,2,(2-2),(2-2), 2,(2-2),(2-2),(2-2),(2-2),(2-2),(2-2),(2-2),(2-2-2), \\
(2-2),(2-1-1),(1-2-1),(2-2-1),(2-1-1),(2-1-1),(2-2-1),(1-1-1-1),(2-1-1-1),(1-1)\end{array}$ & 0 & \\
\hline \multicolumn{4}{|c|}{ B. hermogenesi (Trilha do Ipiranga $50 \mathrm{~m}$ from the Rio Ipiranga) } \\
\hline Ind 01 (MHNCI 188) & $\begin{array}{l}(2-2),(2-2),(2-2),(2-1-1),(2-1-1),(1-1-1-1),(1-1-1),(1-1-1-1),(1-1-1-1),(1-1-1),(1-1-1),(1- \\
1-1),(1-1-1)\end{array}$ & $?$ & \\
\hline Ind 02 (MHNCI 189) & $\begin{array}{l}2,2,2,2,2,2,2,2,2,2,2,2,2,2,2,2,2,2,2, ?, ?, 2,2,(1-2),(2-2),(2-2),(2-2),(3-2),(2-2- \\
2),(2-2),(2-2-2),(2-2-2),(2-2-2),(2-2-2),(2-2-2),(2-2-1),(2-2-2),(2-2),(2-2-2)\end{array}$ & 3 & \\
\hline Ind 03 (MHNCI 190) & $2,2,2,2,2,2,2,2,2,2,2,2,2,2,(2-2),(2-2),(2-2),(2-2),(2-2),(2-2),(2-2),(2-2),(2-2),(2-$ & 3 & \\
\hline
\end{tabular}




\begin{tabular}{|c|c|c|c|}
\hline $\begin{array}{l}\text { Individuals (Ind) and call } \\
\text { deposit number }\end{array}$ & Call structure & A & $\mathrm{B}$ \\
\hline & $2-2)$ & & \\
\hline Ind 04 (MHNCI 191) & $\begin{array}{l}2,2,2,2,2,2,2,2,2,2,2,2,2,2,2,2,2,(2-2),(2-2),(2-2),(2-2),(2-2),(2-2),(2-2),(2-2), \\
(2-2),(2-2),(2-2)\end{array}$ & 4 & \\
\hline Ind 05 (MHNCI 192) & $\begin{array}{l}2,2,2,2,2,2,2,2,2,2,2,2,2,2,2,2,2,2,2,2,2,2,2,2,2,2,2,2,2,2,2,2,2,2,2,2,2,2, \\
2,2,2,2,2,2,2,2,2,2,2,2,2,2,2,2,2,2,(2-2),(2-2),(2-2),(2-2),(2-2),(2-2),(2-2),(2-2), \\
(2-2-2),(2-2),(2-2-2),(2-2-2),(2-2-2),(2-2-2),(2-2-2-2),(2-2-2-2),(2-2-2-1),(2-2-1-2),(2-2- \\
2-1),(2-1-1-1-1),(2-1-1-1-1),(2-1-1-1-1),(2-2-2-1-1),(1-1-1-1-1),(1-1-1-1-1-1),(2-1-1-1-1), \\
(2-2-1-1-1),(1-2-1-1-1),(1-1-1-1-1),(1-1-1-1-1),(1-1-1-1-1),(1-1-1-1-1),(1-1-1-1-1),(1-2-1- \\
1-1),(1-1-1-1-1),(1-2-1-1-1),(1-1-1-1-1),(1-1-1-1-1),(1-1-1-1),(1-1-1-1),(1-1-1-1-1),(2-1- \\
1-1-1),(2-1-2-1-1),(1-2-1-2-1),(2-1-1-2-1),(1-1-1-1-1),(1-2-1-1-2),(1-1-1-1-1),(1-1-1-1), \\
(1-1-1-1-1)\end{array}$ & 3 & \\
\hline \multicolumn{4}{|c|}{ Brachycephalus sp. (Corcovado) } \\
\hline Ind 01 (MHNCI 193) & $(6-4),(6-4),(6-4),(6-4),(6-4),(6-4),(6-1)$ & $?$ & \\
\hline Ind 02 (MHNCI 194) & $1,2,2, ?, 2$ & 0 & $\mathrm{X}$ \\
\hline Ind 03 (MHNCI 195) & $\begin{array}{l}3,3,4,3,4,4,3,3,4,4,3,4,4,4,4,4,4,4,4,4,4,4,4,5,5,4,5,4,4,4,(5-2),(5-4),(5-2), \\
(5-3),(5-2), 6,5,4,(5-1), 5,(5-3),(5-3),(5-1),(6-4),(5-3),(5-4),(5-3),(5-3),(5-3),(5-3),(5- \\
3),(5-4),(5-3), 6\end{array}$ & $?$ & \\
\hline Ind 04 (MHNCI 196), ex 01 & $\begin{array}{l}3,3,2,3, ?, 3, ?, ?, ?, ?, ?, 4,4,4,4,3,3, ?, 4, ?, 3,4,4,5,4,4,5,4,4, ?, ?, 5,5,5,5,(4-3),(?- \\
?),(6-4),(7-4),(9-4),(8-4),(9-5),(9-4),(10-5),(9-6),(11-5),(11-5),(8-5),(6-5),(6-4),(7-4), \\
(6-4), 6,5,5,5,5,5,5,5\end{array}$ & 3 & \\
\hline
\end{tabular}




\begin{tabular}{|c|c|c|c|}
\hline $\begin{array}{l}\text { Individuals (Ind) and call } \\
\text { deposit number }\end{array}$ & Call structure & $\mathrm{A}$ & $\mathrm{B}$ \\
\hline Ind 04 (MHNCI 200), ex 02 & $\begin{array}{l}4,4,4,5,5,4,5,4,4,4,4,5,5,5,(4-3), 5,5,6,(6-3),(7-4),(6-3),(7-3),(8-4),(7-4),(8-4), \\
(?-?),(8-4),(9-4),(9-4),(8-5),(8-5),(8-4),(9-5),(7-4),(8-5),(8-4),(7-6),(6-5),(7-4),(6-5), \\
(6-4), 6,5,7,5,4,5\end{array}$ & 7 & \\
\hline Ind 05 (MHNCI 197) & $(5-3),(5-4), 4,(3-3),(4-3),(4-3), 4,4,4,(3-3), 4,3$ & $?$ & \\
\hline Ind 06 (MHNCI 198), ex 01 & $\begin{array}{l}6,10,4,10,10,12,(13-2),(8-3),(12-2),(9-3), 5,7,11,(9-4),(13-3),(14-5),(16-4),(15-5), \\
(11-5),(9-4),(9-8), 4\end{array}$ & 4 & \\
\hline Ind 06 (MHNCI 199), ex $02^{1}$ & $5,5,4,5,5,4,3,4,5,4$ & $?$ & \\
\hline Ind 07 (MHNCI 201) & $\begin{array}{l}4,3,4,4,5,4,4,4,4,4,5,5,5,5,5,5,5,5,6,(6-4),(7-4),(7-3),(7-4),(7-4),(7-4),(7-4),(7- \\
5),(7-5),(7-5),(7-4),(7-2),(7-5),(7-5),(6-5),(6-5),(7-5),(7-5), 5,6,5,6,5,6,5,6\end{array}$ & 4 & \\
\hline Ind 08 (MHNCI 202) & $2,3,2,3,3,3,3,3,3,3,3$ & 6 & $\mathrm{X}$ \\
\hline Ind 09 (MHNCI 203) & $\begin{array}{l}4,4,4,4,4,4,4,4,4,4,4,4,(4-2),(4-2),(5-3),(4-3),(5-3),(5-3), 5,(5-3),(4-2),(5-3),(5-3), \\
(4-3),(5-3),(5-3), 5,4,5,5,5,5,4,4,4,4,5,4,4,4,4,5,4,4,4,4,4,4,4,3,3\end{array}$ & 2 & \\
\hline Ind 10 (MHNCI 204) & $\begin{array}{l}?, ?, ?, ?, ?, ?, ?, 2,2,3,3,2,2,3,3,3,3, ?, 3,4,4,3,4,4,4,4,(4-2),(4-3), 4,(4-3),(4-2), 4 \\
(4-3),(4-1),(4-2),(4-3),(4-2), 4,(4-3),(4-3),(4-3), 5,3,4,4\end{array}$ & 2 & \\
\hline Ind 11 (MHNCI 205) & $\begin{array}{l}1,1,2,2,2,1,2,2,2,2,2,1,3,2,2,2,2,2,3,2,2,3,3,3,4,3,3,3,4,3,4,4,4,4,4,4,4,4, \\
4,4,4,4,4,4,4,4,4,4,4,4,4,4,4,4,4,4,4,4,4,4,4,4,4,4,4,4,4,4,4,4,4,4,4,4,4,3, \\
3,4\end{array}$ & 2 & \\
\hline Ind 12 (MHNCI 205) & $\begin{array}{l}2,2,2,2,2,2,2,1,2,2,2,2,2,2,2,2,2,2,2,2,2,3,2,2,3,3,3,3,3,3,3,2,3,3,3,3,3,3, \\
3,3,3,3,4,2,1\end{array}$ & 0 & \\
\hline
\end{tabular}




\begin{tabular}{|c|c|c|c|}
\hline $\begin{array}{l}\text { Individuals (Ind) and call } \\
\text { deposit number }\end{array}$ & Call structure & A & $\mathrm{B}$ \\
\hline Ind 01 (MHNCI 206) & (?-?),(?-?),(?-?),(?-?),(5-?),(?-?),(?-?),(4-?),(?-?),(?-?),(?-?) & $?$ & \\
\hline Ind 02 (MHNCI 207) & $3,(4-3),(4-3),(4-3),(4-3),(4-3),(4-3),(4-3),(4-3),(3-3),(3-3),(3-3),(4-3),(4-3),(3-3)$ & $?$ & \\
\hline Ind 03 (MHNCI 208) & $\begin{array}{l}4,3,4,4,4,4,4,4,4,4,4,4,4,4,4,4,5,5,(4-4), 5,(4-3), 4,(4-4),(5-4),(4-4),(4-3),(4-4), \\
4,5,5,5,(5-3), 4\end{array}$ & $?$ & \\
\hline Ind 04 (MHNCI 209) & $\begin{array}{l}2,3,3, ?, 3,3,4,(3-3),(4-3),(4-3),(4-3),(3-3),(4-3),(4-3),(4-3),(3-3),(4-3),(4-3),(4-3), \\
(3-3),(3-2), 3,(3-2)\end{array}$ & $?$ & \\
\hline Ind 05 (MHNCI 210) & $4,4,4,4,4,4,4,4,(4-3), 4,(4-3),(4-3), 4,(4-3),(4-3),(4-3)$ & 5 & $\mathrm{X}$ \\
\hline Ind 06 (MHNCI 211) & $\begin{array}{l}4,(4-3),(3-3),(4-3),(4-4),(4-3),(4-4),(3-3),(4-4),(4-4),(4-4),(4-4),(4-3),(4-3),(4-4),(4- \\
4),(3-4-4),(3-4-3),(4-4),(4-4),(3-3-3),(4-3-3),(3-3-3),(3-2-3),(3-2-3),(3-3),(3-2)\end{array}$ & $?$ & \\
\hline Ind 07 (MHNCI 212) & $3,(3-2),(3-3),(3-3),(3-3),(3-3),(3-3),(3-3),(3-3),(3-3),(3-3)$ & $?$ & \\
\hline
\end{tabular}

${ }^{1}$ Only the final part of the advertisement call was recorded. 


\section{Table 3 (on next page)}

Parameters distinguishing the advertisement calls of flea toads at some point identified as $B$. sulfuratus and $B$. hermogenesi, including call comparisons of a third flea toad (Brachycephalus sp.)

Table 3. Parameters distinguishing the advertisement calls of flea toads at some point identified as Brachycephalus sulfuratus and B. hermogenesi, including call comparisons of a third flea toad (Brachycephalus sp.), originally identified as $B$. hermogenesi. 
1 Table 3. Parameters distinguishing the advertisement calls of flea toads at some point identified as

2 Brachycephalus sulfuratus and B. hermogenesi, including call comparisons of a third flea toad

3 (Brachycephalus sp.), originally identified as B. hermogenesi.

Brachycephalus. sp. from

Parameter B. sulfuratus B. hermogenesi Corcovado and Trilha do

Corisco

Note-centered approach

Number of notes per call

$\leq 8 \quad \geq 24$

$\geq 38$

Calls composed only by isolated

$\mathrm{X}$ notes

Calls present note groups

Presence of warming notes

$\mathrm{X}-\mathrm{x}$

Presence of attenuated notes

Maximum number of pulses in

142

12

isolated notes

Maximum number of pulses per

$---3$

16

note in note groups

Maximum number of notes in

$---\quad 6^{1}$

3

note groups

\begin{tabular}{lccc}
\hline Call-centered approach & & & \\
\hline Number of notes per call & 1 & --- & --- \\
Calls composed only by isolated & --- & & --- \\
notes & & --- & --- \\
Calls present note groups & --- & --- & --- \\
Presence of warming notes & --- & --- & --- \\
Presence of attenuated notes & --- & --- & --- \\
Maximum number of pulses in & --- & & \\
isolated notes & & --- & 16 \\
Maximum number of pulses per & --- & & \\
note in note groups & & 14 & 3
\end{tabular}


Brachycephalus. sp. from

Parameter B. sulfuratus B. hermogenesi Corcovado and Trilha do

Corisco

Note-centered approach

note

Maximum number of notes in

$---$

$---$ note groups

$4 \sqrt{1}$ Up to seven, according Verdade et al. (2008). 


\section{Figure 1}

Ventral view of life specimens of Brachycephalus sulfuratus

Figure 1. Ventral view of life specimens of Brachycephalus sulfuratus initially deposited in DZUP) and transferred to $\mathrm{MHNCl}$. a) MHNCI 11575 (ex-DZUP 153) (Corvo, Paraná); b) MHNCl 11571 (ex-DZUP 139)(Caratuval, near the Parque Estadual das Lauráceas, Paraná); c) MHNCI 11582 (ex-DZUP 224) (Fazenda Thalia, Paraná); d) MHNCI 11579 (ex-DZUP 221) (Fazenda Thalia); e) MHNCI 11573 (ex-DZUP 151) (Corvo); f) MHNCI 11583 (ex-DZUP 362) (base of the Serra Água Limpa, São Paulo); g) MHNCl 11580 (ex-DZUP 222) (Fazenda Thalia); h) MHNCI 11581 (ex-DZUP 223) (Fazenda Thalia); i) MHNCl 10788 (ex-DZUP 154) (Corvo); j) MHNCI 10790 (near the Jurupará dam, São Paulo); k) MHNCl 10826 (Morro do Garrafão, Santa Catarina); I) $\mathrm{MHNCl} 10792$ (near the Jurupará dam). Notice the variable of yellow spots, absent in specimen "I", as well as the absence of the dark-brown inverted v-shaped mark on the cloacal region of specimen "a". Compare sonograms from specimens " $\mathrm{j}$ " and "I" in Fig.

$2 \mathrm{~b}, \mathrm{c}$. The presence of yellow spots and $\mathrm{v}$-shaped mark was proposed as diagnostic characteristics to distinguish $B$. sulfuratus from $B$. hermogenesi, but they are variable intraspecifically. For details on geographical localities, see Table 1. Photo credit: Luiz Fernando Ribeiro. 

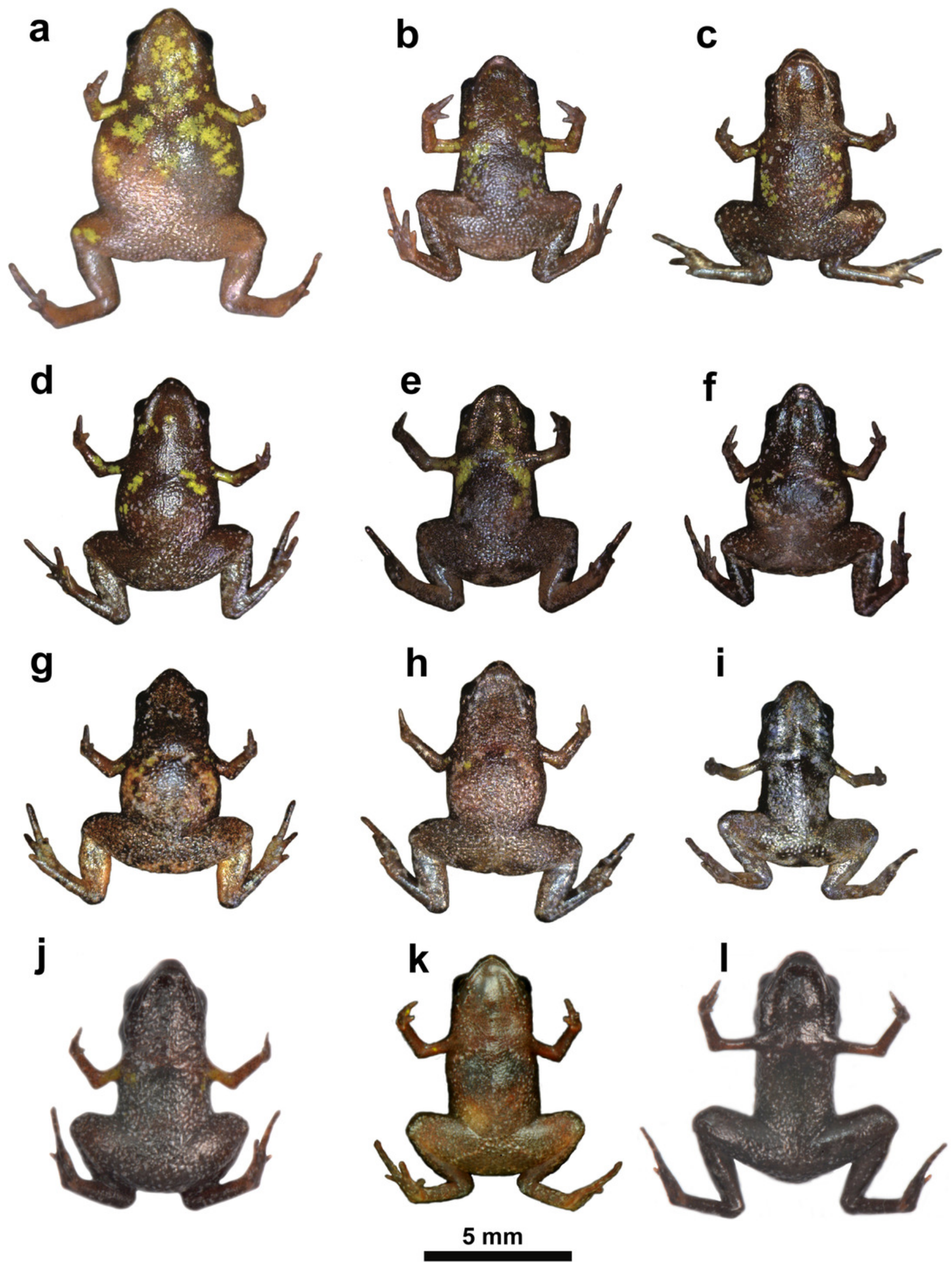


\section{Figure 2}

Ventral view of specimens of Brachycephalus sulfuratus and B. hermogenesi

Figure 2. Ventral view of specimens of Brachycephalus sulfuratus (a-c) and B. hermogenesi (d) in preservative, deposited in MHNCI and ZUEC: a) MHNCI 9800 (Salto do Inferno, Paraná); b) MHNCI 10302 (Mananciais da Serra, Paraná); c) MHNCI 10303 (Corvo, Paraná; ex DZUP 589); and d) ZUEC 9715 (Núcleo Picinguaba, São Paulo; holotype of B. hermogenesi). Notice the variation in ventral coloration. For details on geographical localities, see Table 1. Photo credit: Luiz Fernando Ribeiro. 


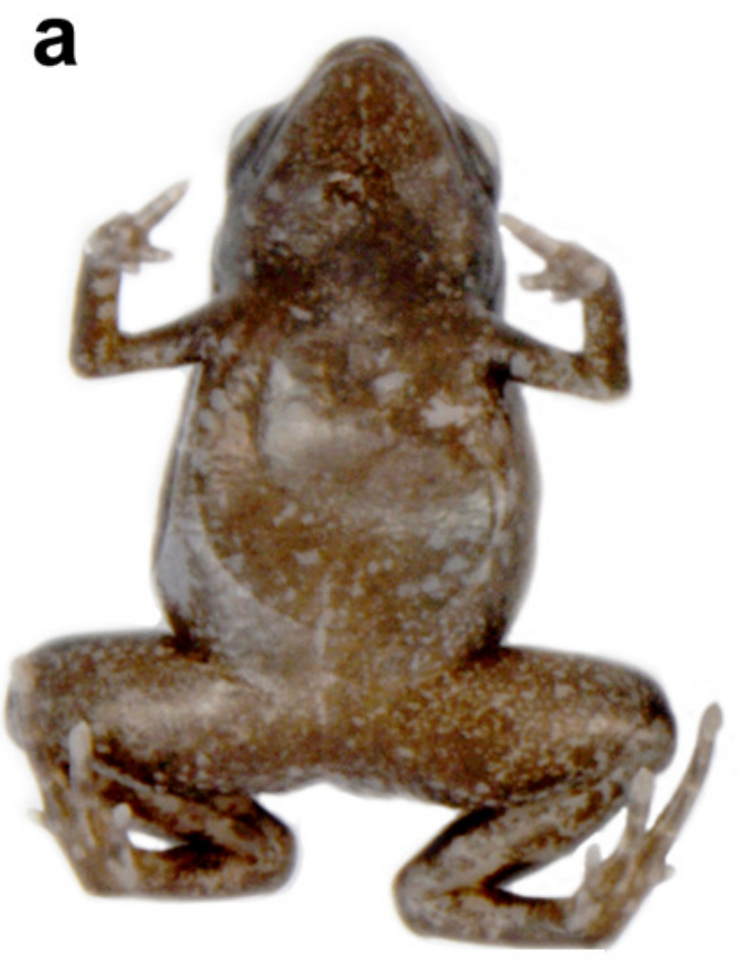

$5 \mathrm{~mm}$

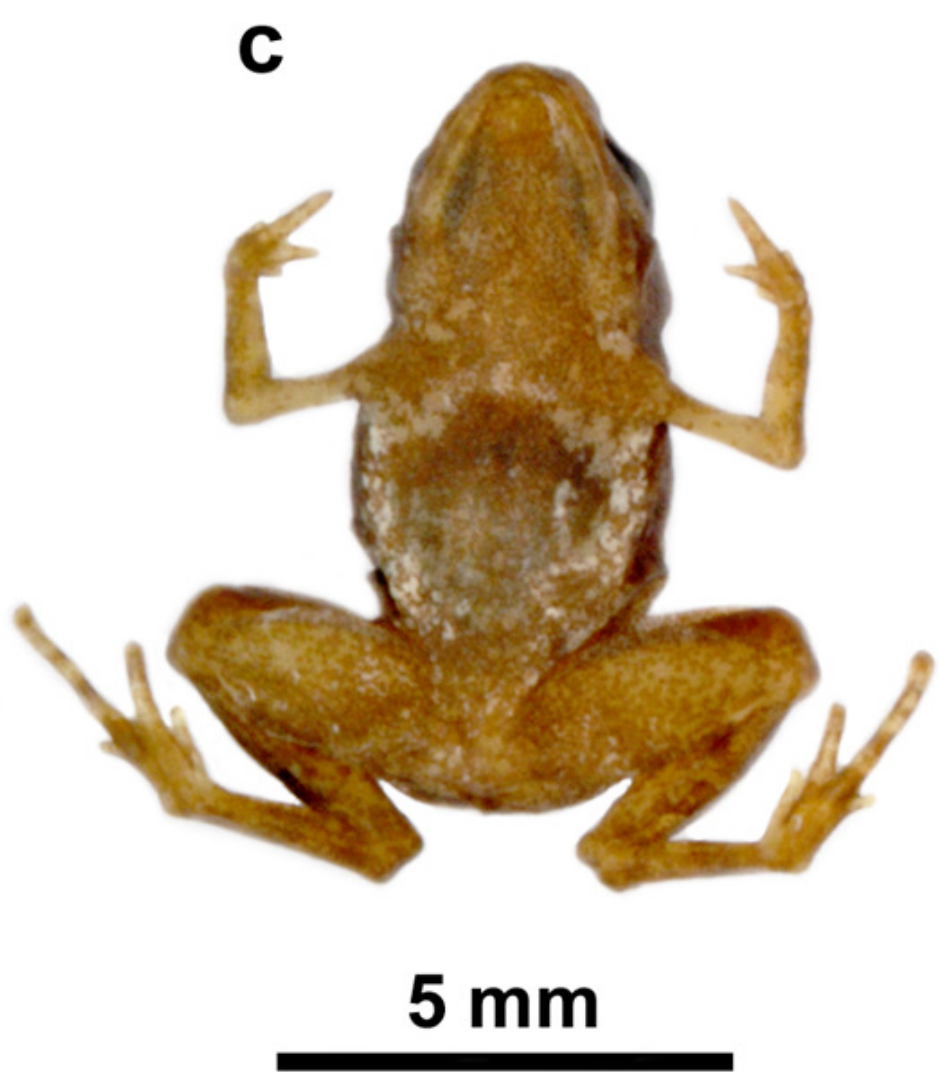

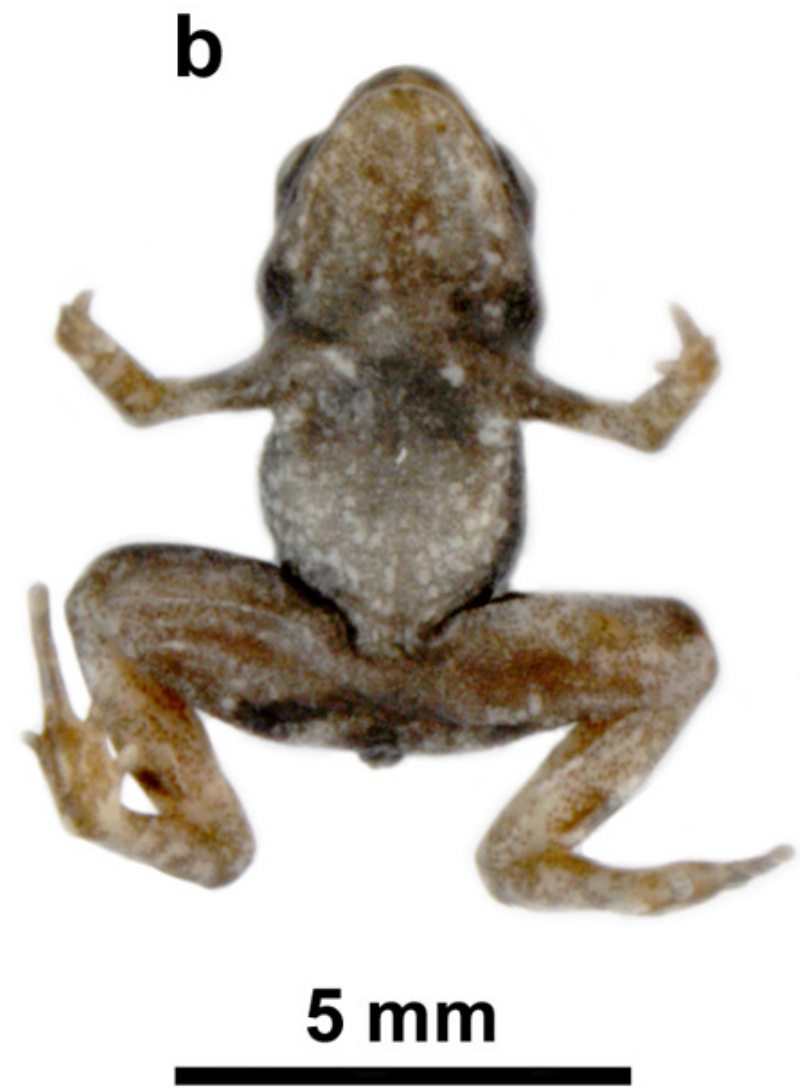

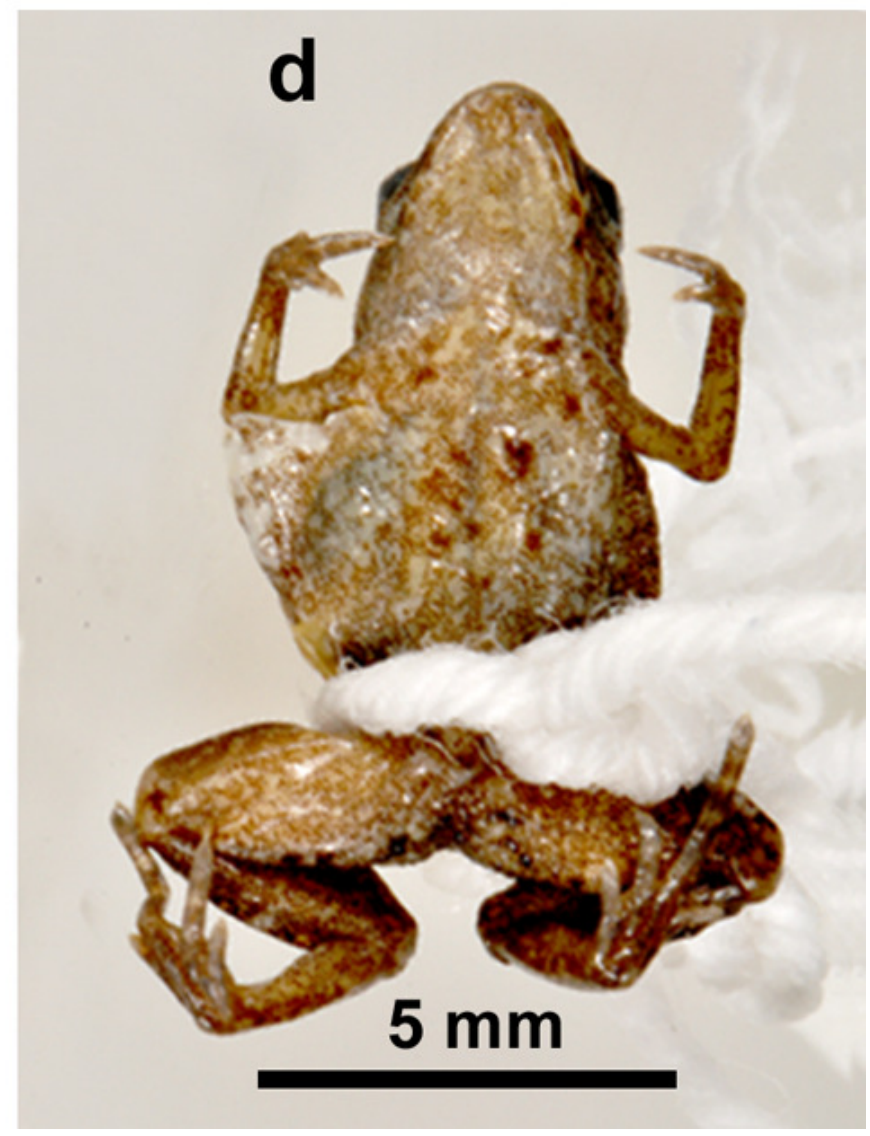




\section{Figure 3}

Oscillograms and spectrograms of Brachycephalus sulfuratus

Figure 3. Oscillograms (above) and spectrograms (below) of Brachycephalus sulfuratus. A. Example of one entire call with five notes (MHNCl 124; voucher MHNCI 10791 or MHNCI 10792; near the Jurupará dam, municipality of Piedade, São Paulo; M. R. Bornschein). B. Example of one entire call with two notes (MHNCl 129; voucher MHNCl 11583; Base of the Serra Água Limpa, municipality of Apiaí, São Paulo; M. R. Bornschein). C. Example of one note with 10 pulses (MHNCl 124). D. Example of one note with three pulses (MHNCl 124). Spectrograms are produced with Hann window, overlap of $50 \%$, and FFT size of 512 points in $A$ and $B$ and 256 points in C and D. For details on geographical localities, see Table 1. 

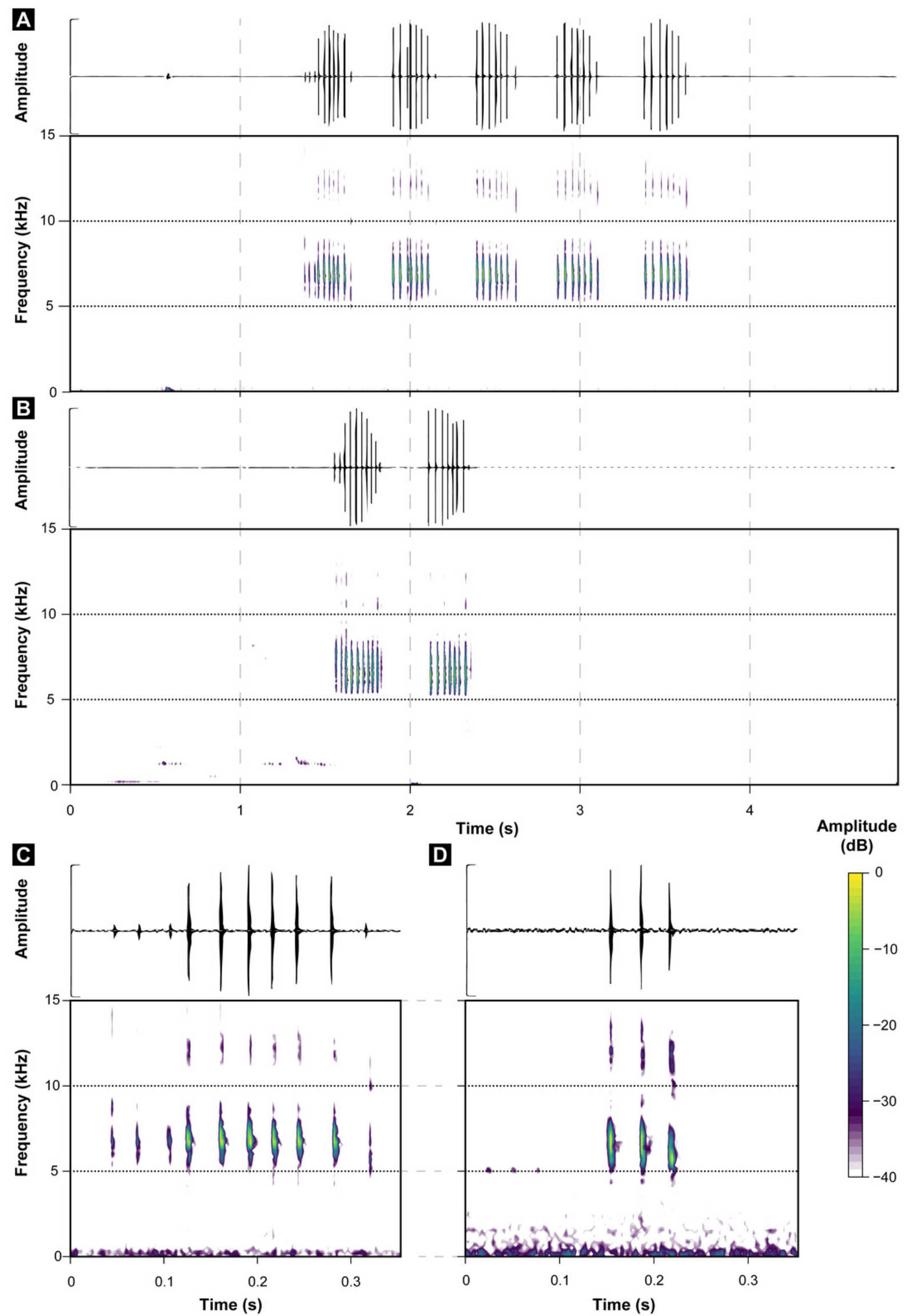

D

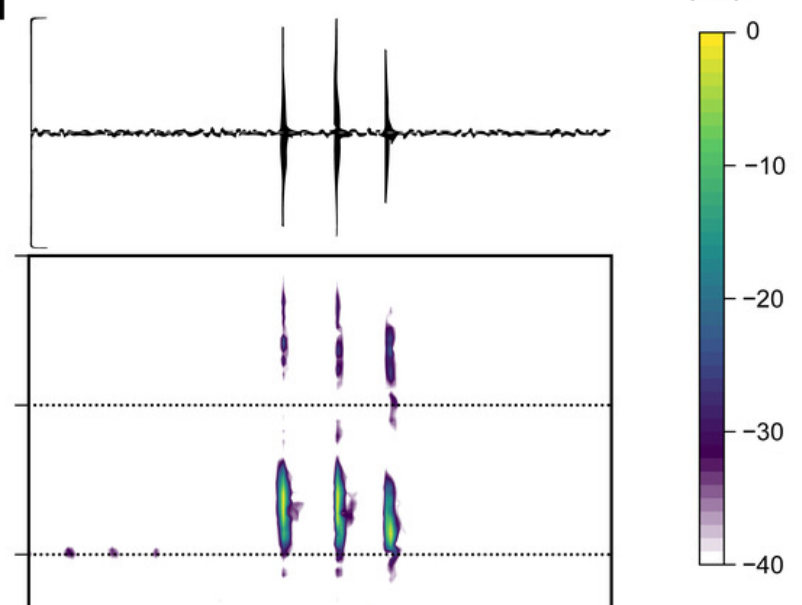

Peer) reviewing PDF | (2020:08:52328:1:1:NEW 5 Jan 2021) 


\section{Figure 4}

Oscillograms and spectrograms of Brachycephalus hermogenesi

Figure 4. Oscillograms (above) and spectrograms (below) of Brachycephalus hermogenesi. A. Example of one entire call with 135 notes recorded (MHNCl 165; Corcovado, municipality of Ubatuba, São Paulo; L. F. Ribeiro). B. Example of one isolated note with two pulses (MHNCl 183; Núcleo Picinguaba, Parque Estadual da Serra do Mar, municipality of Ubatuba, São Paulo ; M. R. Bornschein). C. Example of one note group with three notes (each with two pulses; MHNCI 180; Núcleo Picinguaba; M. R. Bornschein). D. Example of one note group with four notes (each with two pulses; MHNCl 165). E. Example of one note group with three notes (the first with three pulses and the remaining with two pulses; MHNCl 166; Estação Biológica de Boracéia, municipality of Salesópolis, São Paulo; M. R. Bornschein). F. Example of one note group with three notes, with each note preceded by an attenuated note with one pulse (marked with white arrows; $\mathrm{MHNCl}$ 183). Spectrograms are produced with Hann window, overlap of $50 \%$, and FFT size of 16,384 points in A, 128 points in B, and 256 points in C-F. 
A

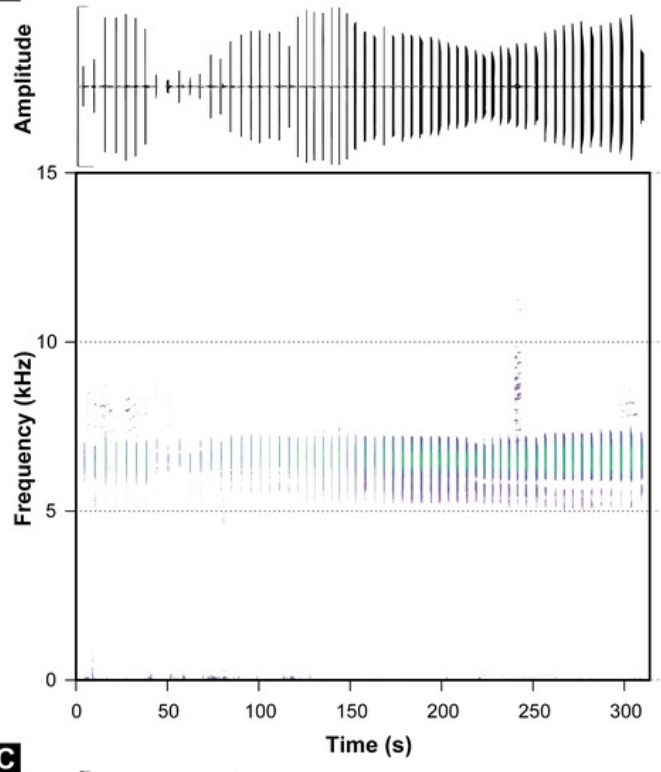

C

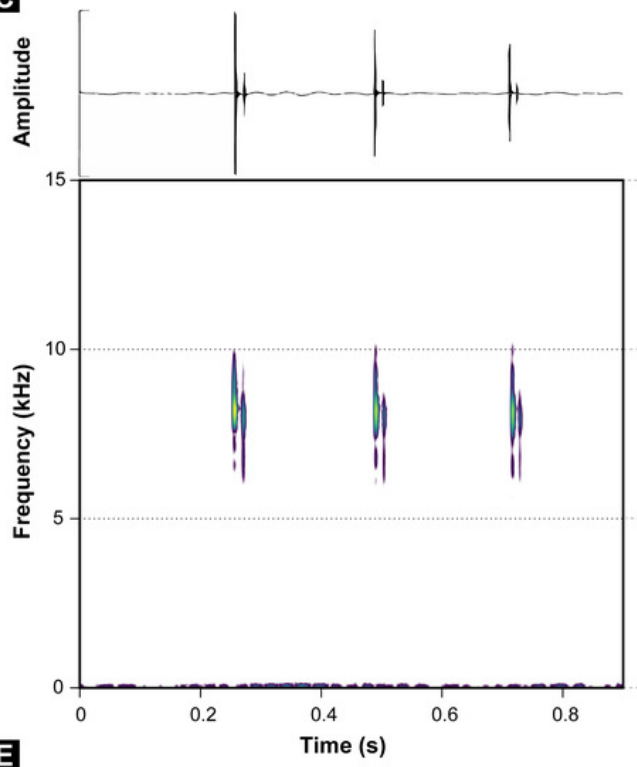

目

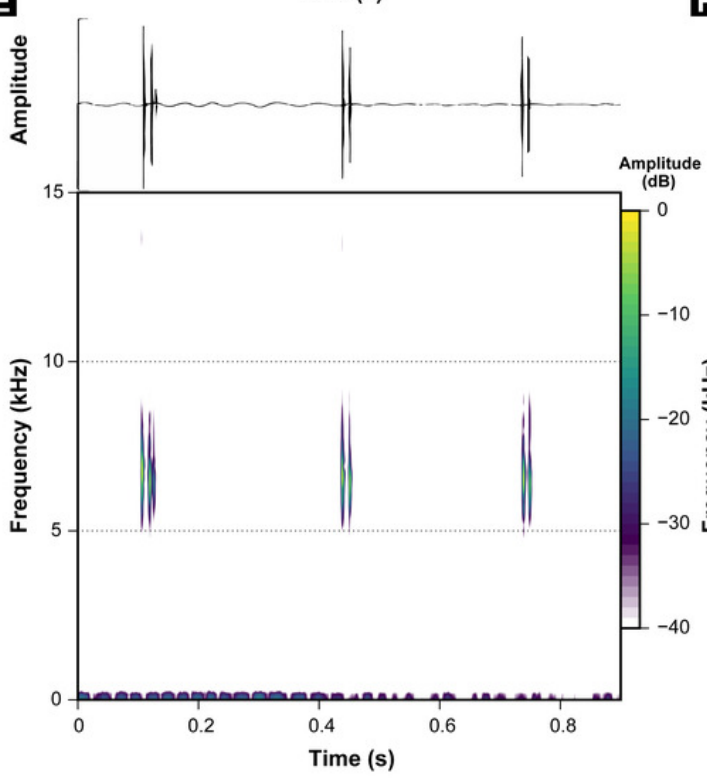

B

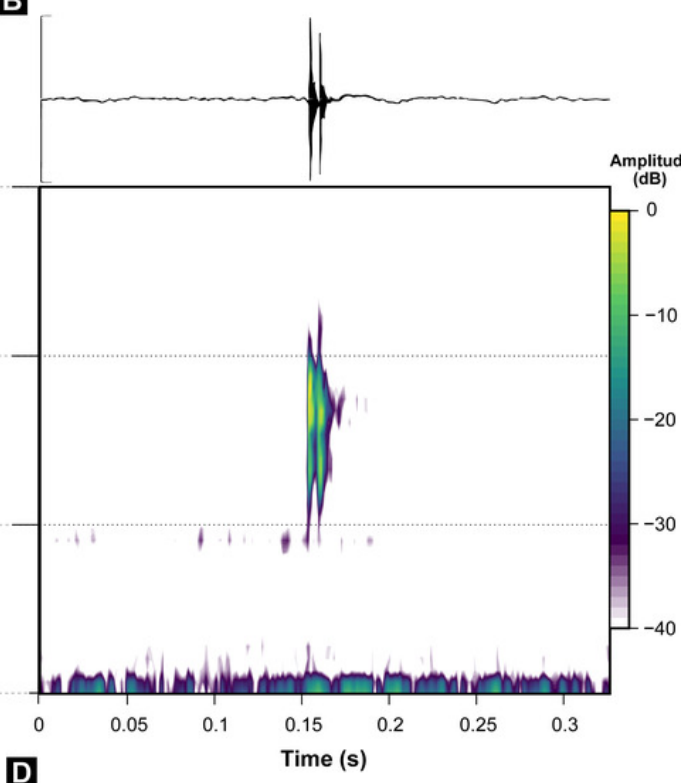

D

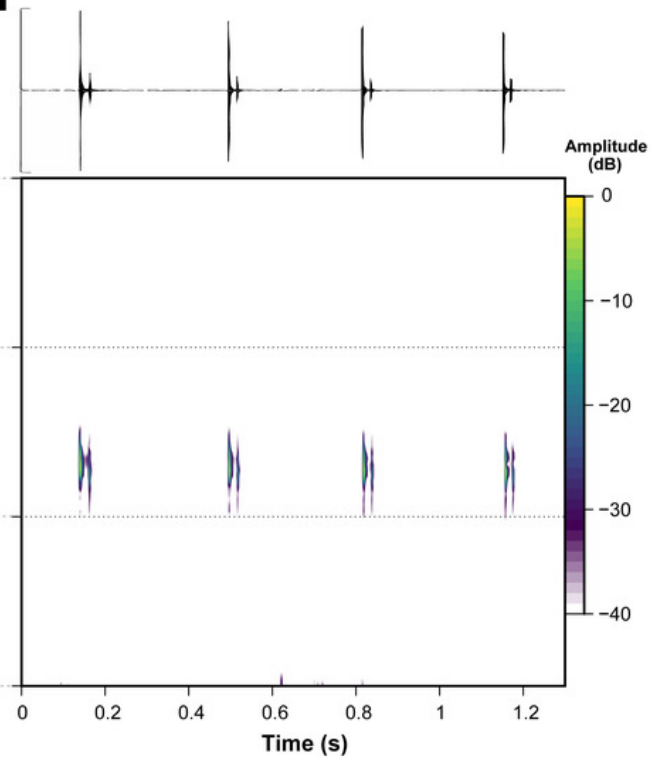

百

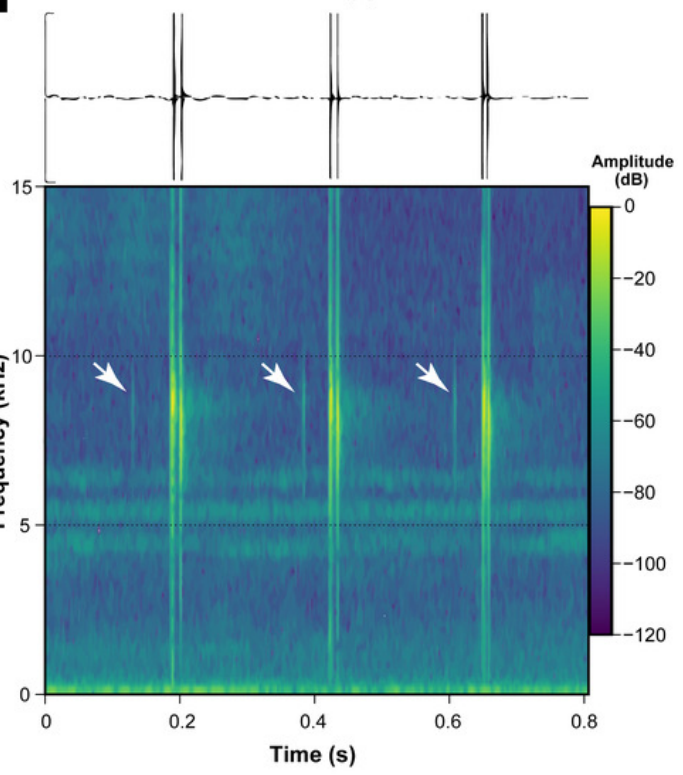




\section{Figure 5}

Oscillograms and spectrograms of Brachycephalus sp. (other than B. sulfuratus and $B$. hermogenesi)

Figure 5. Oscillograms (above) and spectrograms (below) of Brachycephalus sp. (other than B. sulfuratus and B. hermogenesi). A. Example of one entire call with 71 notes recorded (MHNCl 200; Corcovado, municipality of Ubatuba, São Paulo; M. R. Bornschein). B. Example of one isolated note with seven pulses (MHNCl 198; Corcovado; M. R. Bornschein). C. Example of one note group with two notes (with nine and four pulses, respectively; $\mathrm{MHNCl}$ 198). D. Example of one note group with three notes (the first note with three pulses and the remaining notes with four pulses; $\mathrm{MHNCl} 211$; Trilha do Corisco, municipality of Paraty, Rio de Janeiro; L. F. Ribeiro). Spectrograms are produced with Hann window, overlap of $50 \%$, and FFT size of 16,384 points in A and 256 points in B-D. 


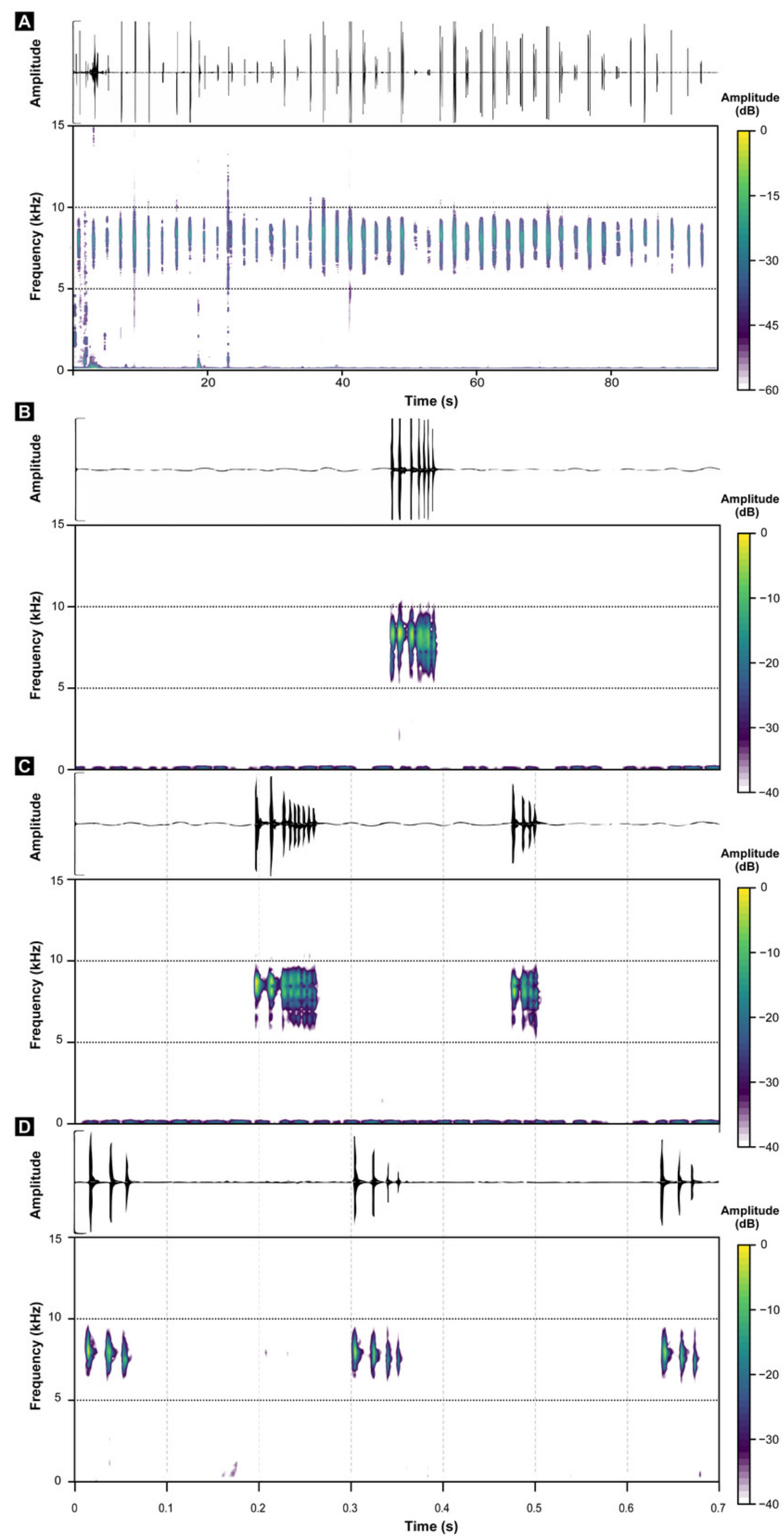




\section{Figure 6}

Current identification of records of flea toads that have been at some point identified as Brachycephalus sulfuratus, $B$. hermogenesi, and as an unidentified related species

Figure 6. Current identification of records of flea toads that have been at some point identified as Brachycephalus sulfuratus, $B$. hermogenesi, and as an unidentified related species, according to the compilation of localities and review of identifications shown in Table 1. We highlighted the southernmost record of $B$. hermogenesi confirmed ( 1 - Parque Natural Municipal Nascentes de Paranapiacaba). We also highlight the northernmost confirmed records of $B$. sulfuratus ( 2 - Núcleo Itutinga-Pilões and 3 - near the Jurupará dam). Abbreviations: RJ = Rio de Janeiro; SP = São Paulo; PR = Paraná; SC = Santa Catarina. Map image is the intellectual property of Esri and is used herein under license. Copyright $\odot 2020$ Esri and its licensors. All rights reserved. 


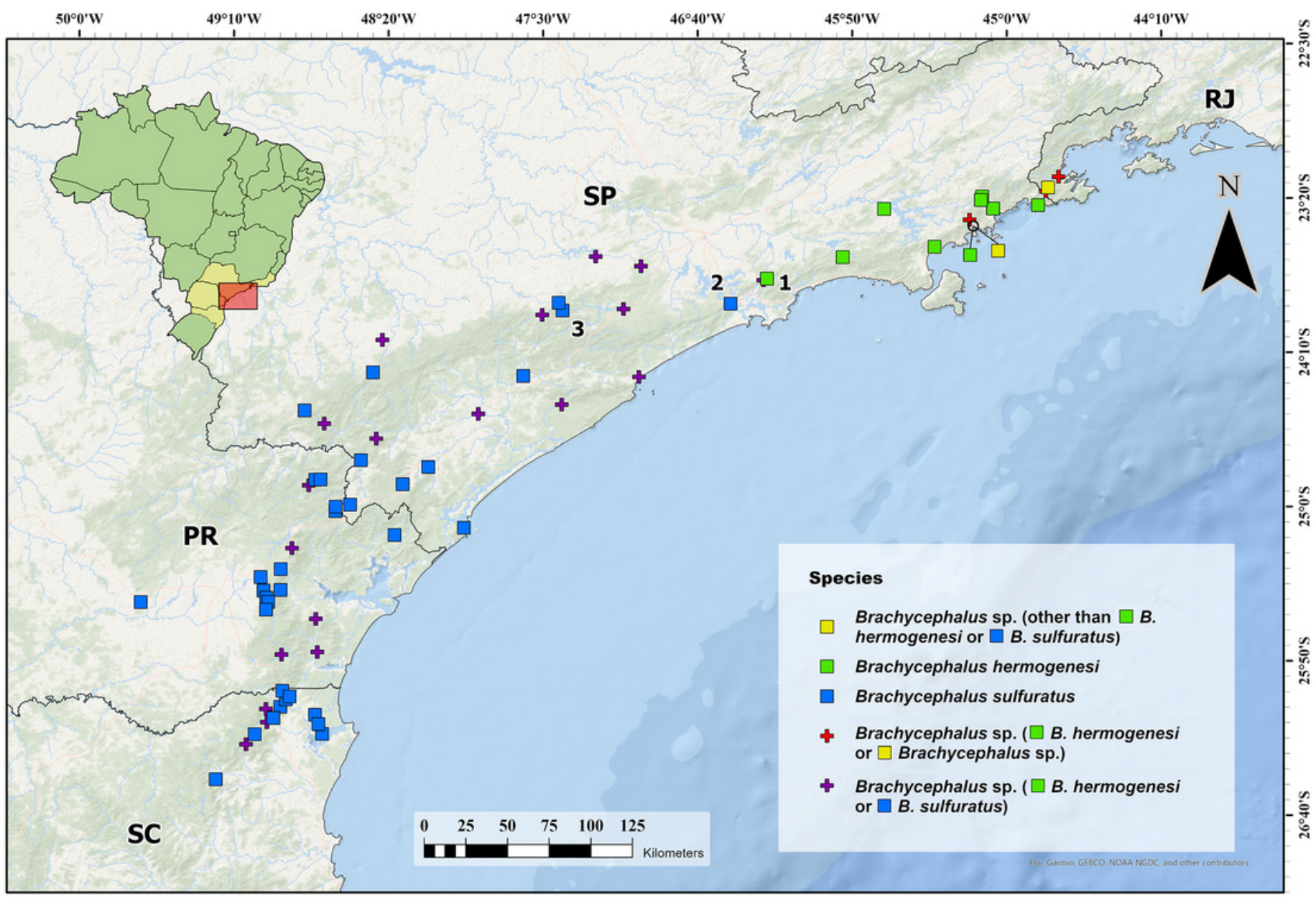




\section{Figure 7}

Phylogenetic tree based on a concatenated dataset of all mitochondrial $12 \mathrm{~S}$ and $16 \mathrm{~S}$ mitochondrial loci available on GenBank for specimens of the B. didactylus species group

Figure 7. Phylogenetic tree based on a concatenated dataset of all mitochondrial $12 S$ and $16 \mathrm{~S}$ mitochondrial loci available on GenBank for specimens of the $B$. didactylus species group (Table S1). The tree was rooted by its midpoint. Whenever possible, the corresponding localities available on their GenBank records were standardized based on the toponyms indicated in Table 1. Notice that the specimen originally identified as $B$. hermogenesi from the Municipality of Piedade (Condez, Sawaya \& Dixo 2009, Clemente-Carvalho et al. 2011), was reverted to $B$. sulfuratus (Table 1). Branch values correspond to bootstrap support. 


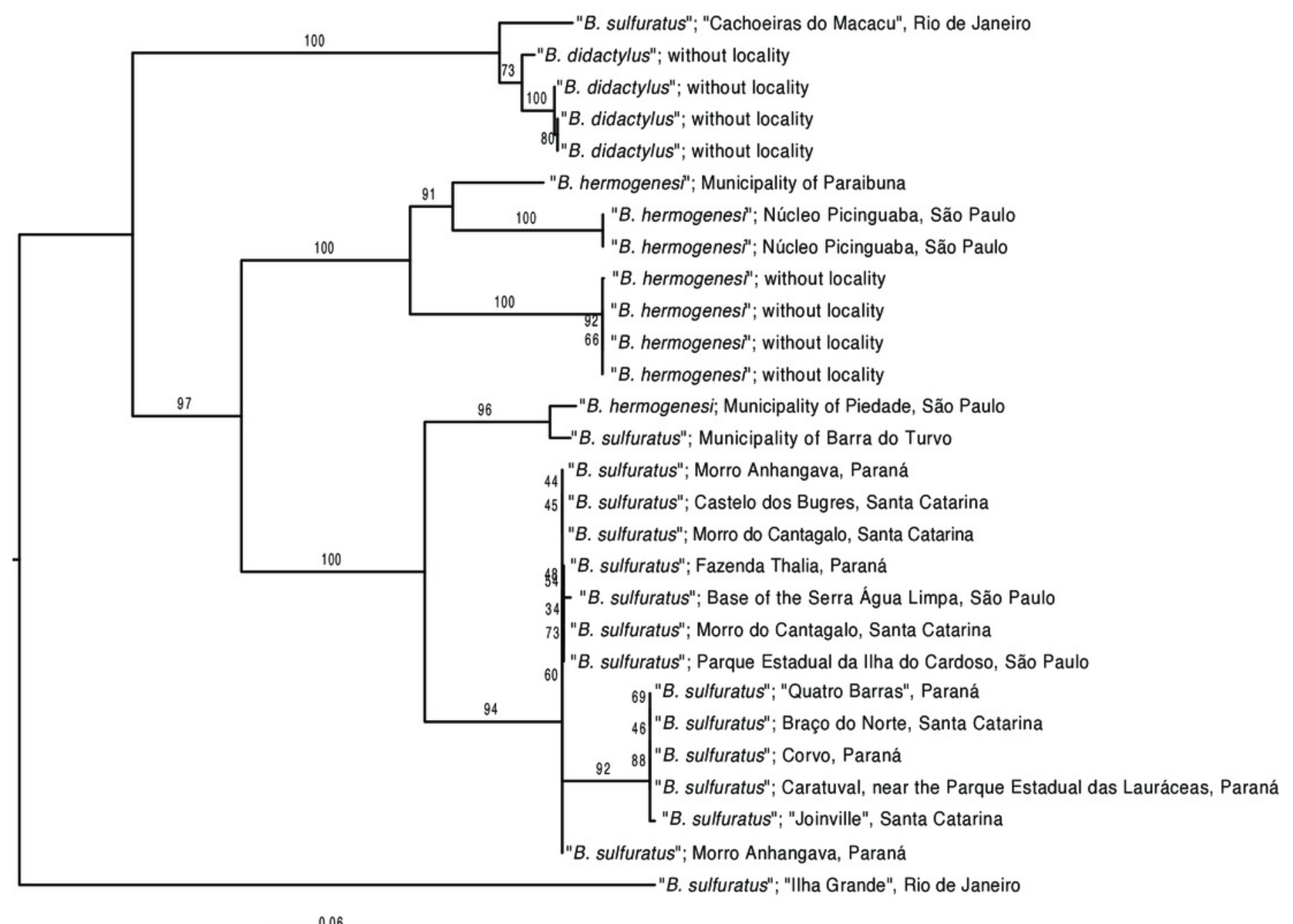

